\title{
EFEITO DA MATÉRIA ORGÂNICA EM ALGUNS ATRIBUTOS DO SOLO.
}

\author{
MILTON PAULINO DA COSTA
}

Orientador: Prof. Dr. ZILMAR ZILLER MARCOS

Dissertação apresentada à Escola Superior de Agricultura "Luiz de Queiroz", da Universidade de São Paulo, para obtenção do título de Mestre em Agronomia. Área de Concentração: Solos $\theta$ Nutrição de Plantas.

PIRACICABA

Estado de São Paulo - Brasil

Novembro, 1983 
A Marlene Costa

- Esposa e companheira de todas as horas.

Aos filhos Milton e Juliene

- O estimulo constante

Aos pais e irmãos

- A gratidão

Dedico. 


\section{AGRADECIMENTOS}

- Ampresa Brasileira de Pesquisa Agropecuária, pela oportunidade da realização do curso.

- Aos responsáveis pelo Centro de Pesquisa Agropecuária do Trópico Umido (CPATU) pelo apoio prestado.

- Escola Superior de Agricultura "Luiz de Queiroz" pela oportunidade na participação do curso.

- Ao Prof.Dr. Zilmar Ziller Marcos, pela orientação e sobretudo pelo incentivo durante o curso e realização deste trabalho.

- Aos docentes do Departamento de Solos, Geologia e Fertilizantes da Escola Superior de Agricultura "Luiz de Queiroz" pelos estímulos, exemplos e ensinamentos.

- Ao colega Eloy Antonio Pauletto, pelas inúmeras sugestões sobre vários aspectos do trabalho.

- Aos funcionários do Departamento de Solos, Geologia e Fertilizantes, em especial, ao Sr. Vinicius Ferraz. 
RESUMO $\ldots \ldots \ldots \ldots \ldots \ldots \ldots \ldots \ldots \ldots \ldots \ldots \ldots \ldots \ldots \ldots \ldots \ldots$

SUMMARY $\ldots \ldots \ldots \ldots \ldots \ldots \ldots \ldots \ldots \ldots \ldots \ldots \ldots \ldots \ldots$

1. INTRODUÇÃ̃o $\ldots \ldots \ldots \ldots \ldots \ldots \ldots \ldots \ldots \ldots \ldots \ldots$

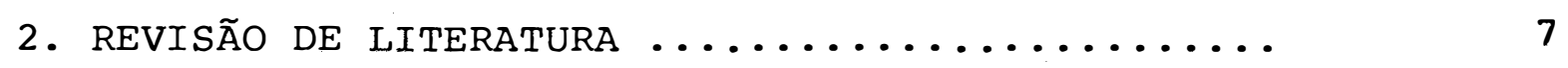

2.1. Efeito da matéria orgânica nos atributos

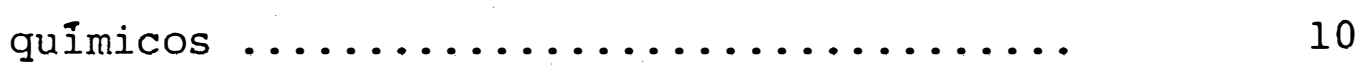

2.2. Efeito do teor de matéria orgânica na grà

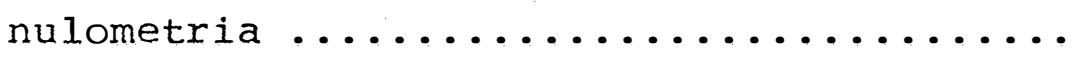

2.3. Efeito do teor de matéria orgânica na densidade do solo (Ds) e na densidade das particulas $(D p) \quad \ldots \ldots \ldots \ldots \ldots \ldots \ldots \ldots \ldots \ldots \ldots \ldots \ldots \ldots$

2.4. Efeito do teor de matéria orgânica na retenção de água no solo a diferentes poten-

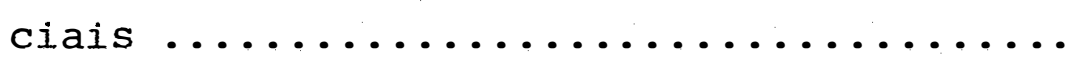

2.5. Efeito do teor de matéria orgânica na eva-

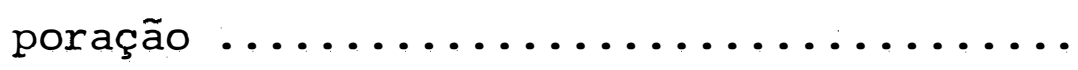

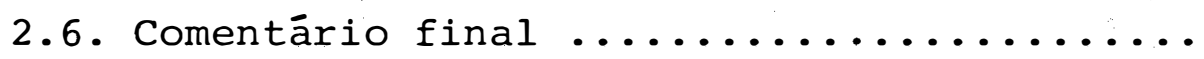

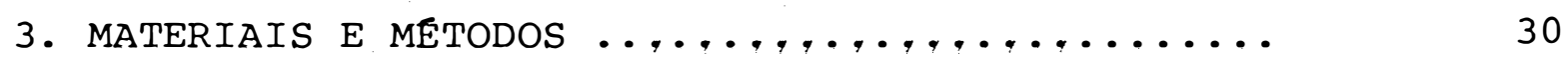

3.1. Materiais ...................... 30

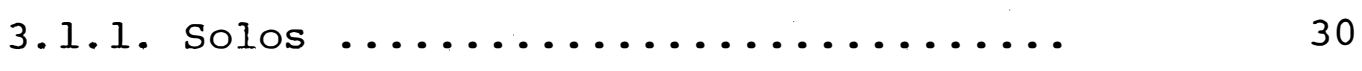

3.1.2. Material orgânico ............ 32

3.2. Métodos ....................... 34 
pāgina

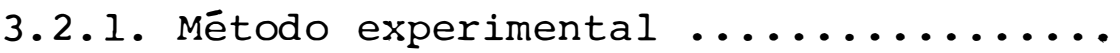

3.2.2. Método operacional ..............

3.2.2.1. Montagem dos tratamentos

3.2.2.2. Determinação do teor de água para irrigação dos tratamentos $\ldots \ldots \ldots \ldots \ldots \ldots$

3.2.2.3. Incubação da amostra de ter$r a \ldots \ldots \ldots \ldots \ldots \ldots \ldots$

3.2.2.4. Coleta de dados e métodos

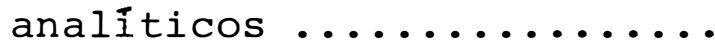

4. RESULTADOS E DISCUSSÃO .................

4.1. Experimento 1: Efeito do teor de matéria orgânica em alguns atributos químicos do solo.

4.2. Experimento 2: Efeito do teor damatéria or-

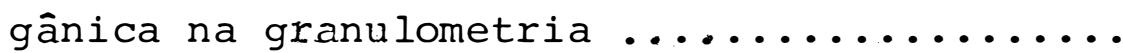

4.3. Experimento 3: Efeito do teor de matéria orgânica na densidade do solo (Ds) e na den-

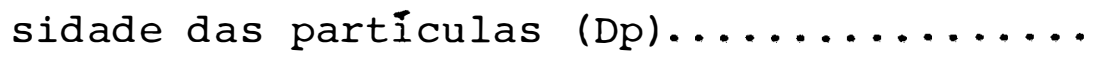

4.4. Experimento 4: Efeito do teor de matéria orgânica na retenção de āgua a diferentes potenciais $\ldots \ldots \ldots \ldots \ldots \ldots \ldots \ldots \ldots \ldots \ldots \ldots \ldots \ldots \ldots$ 
iii.

Pāgina

4.5. Experimento 5: Efeito do teor de matéria orgânica na evaporação da ãgua do solo.

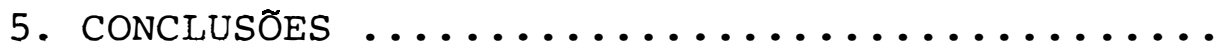

6. CONSIDERAÇÕES FINAIS ................

7. LITERATURA CITADA ................

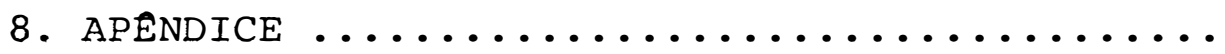


1 - Teores de carbono, argila e óxido de ferro das amostras utilizadas $\ldots \ldots \ldots \ldots \ldots \ldots \ldots \ldots$

2 - Dados quỉmicos dos materiais orgânicos utili zados e da mistura na proporção $1: 1: 1$. (Os resultados representam a média de 3 repetições).

3 - Teores de água para os tratamentos $0 \%, 4 \%$ e 10 \% de matéria orgânica, determinados pelo mé-

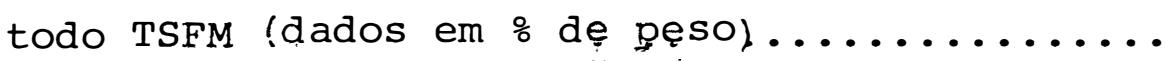

4 - Teor de água para o controle de irrigação de todos os tratamentos durante o período de incubação (teores extrapolados dos valores da

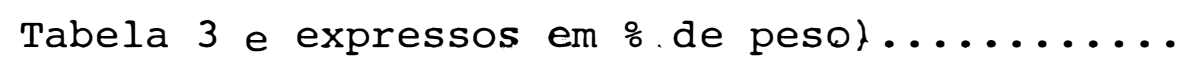

5 - Efeito do teor de matéria orgânica em alguns atributos químicos do horizonte Ap de um Latossolo Roxo. Dados referentes à: média de três repetições, resultados da análise estatística para cada variável e correlação entre variáveis e o teor de carbono ( $\%$ C) $\ldots \ldots \ldots \ldots \ldots \ldots$ 
6 - Efeito do teor de matéria orgânica em alguns atributos químicos do horizonte B2 de um Latossolo Roxo. Dados referentes à: média de : 3 repetições, resultados da anālise estatística para cada variável e correlação entre as variáveis e o teor de carbono ( 8 C) ...........

7 - Efeito do teor de matéria orgânica em alguns atributos químicos do horizonte Al de um Podzólico Vermelho-Amarelo. Dados referentes à: média de 3 repetições, resultados da análise estatística para cada variável e correlação entre as variáveis e o teor de carbono ( 8 C) ...

8 - Efeito do teor de matéria orgânica em alguns atributos químicos do horizonte A2 de um Pod zólico Vermelho-Amarelo. Dados referentes à: média de 3 repetições, resultados da análise estatistica para cada variável e correlação entre as variáveis e o teor de carbono ( 8 c).

9 - Efeito do teor de matéria orgânica em alguns atributos químicos do horizonte B2 de um Podzólico Vermelho-Amarelo. Dados referentes à: mēdia de 3 repetições, resultados da análise estatística para cada variável e correlação entre as variáveis e o teor de carbono ( 8 c).... 
10 - Acréscimos no teor de carbono, a partir do tratamento testemunha, em consequência do acréscimo de matéria orgânica aplicada, expressa em $\&$ de peso e em $t / h a$, para os 5 horizontes ......

11 - Efeito do teor de matéria orgânica na granulo metria dos horizontes Ap e B2 de um Latossolo Roxo. Dados referentes à: média de 3 repetições., resultados da análise estatística para cada variável e correllação entre as variáveis e teor

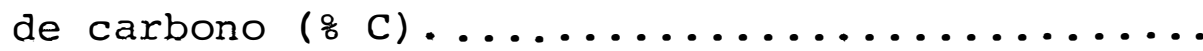

12 - Efeito do teor de matéria orgânica na granulo metria dos horizontes Al, A2 e B2 de um Podzó lico Vermelho-Amarelo. Dados referentes à: média de 3 repetições, resultados da análise estatística para cada variável e correlação entre as variáveis e teor de carbono (\% c) ..........

13 - Efeito do teor de matéria orgânica em alguns atributos físicos dos horizontes Ap e B2 de um Latossolo Roxo. Dados referentes à:média de 3 repetições, resultados da análise estatística para cada variável e correlação entre variáveis e \% C. ( $D$ s=densidade do solo; $D p=$ densidade das partículas; $E=$ porosidade total; $\% \mathrm{U}=$ teor de āgua em que a D.sfoi determinada; $8 \theta=$ teor de água em volume; $\% \mathrm{Pla}=$ porosidade livre de água ........ 
14 - Efeito do teor de matéria orgânica em alguns atributos físicos dos horizontes Al, A2 e B2 de um Podzólico Vermelho-Amarelo. Dados referentes à: média de 3 repetições, resultados da análise estatística para cada variável e correlação entre variáveis e ơc. (Ds=densidade do solo; Dp=densidade das partículas; $\frac{8}{8}=$ porosidade total; $8 \mathrm{U}=$ teor de água em volume; ঃPla $=$ porosidade livre da água $\ldots \ldots \ldots \ldots$

15 - Efeito do teor de matéria orgânica na retenção de água (dados em \% de peso) por um Latossolo Roxo em diversos potenciais (atm). Dados referentes à: média de 3 repetições, resultados da análise estatística para cada variável e correlação entre variáveis e o.C. ( $\Delta .05=$ DMS de Tukey; * significativo a $5 \%, * *=$ significativo a $1 \%$ )..

16 - Efeito do teor de matéria orgânica na retenção de água (dados em ơ de peso) por um Podzólico Vermelho-Amarelo em diversos potenciais (atm).Dados referentes à: média de 3 repetições, resultados da análise estatística para cada variá vel e correlação entre variáveis e $\stackrel{\circ}{ } \mathrm{C}$. ( $\Delta .05=$ DMS de Tukey; * = significativo a $5 \%$ e ** = significativo a 1 \%) $\ldots \ldots \ldots \ldots \ldots \ldots \ldots$ 
Pāgina

17 - Teor de água aplicado aos tratamentos durante a incubação e cultura do painço (Setaria italica Beauv) e respectivos potenciais, para cada ho rizonte estudado ....................

18 - Efeito do teor de matéria orgânica na evaporação da água no horizonte Ap do Latossolo Roxo (grama de água por vaso). Dados referentes à: média de 3 repetições $(\bar{x})$, data da irrigação e quantidade de àgua adicionada para manter os tratamentos com teor de àgua estipulado, resultados da análise estatística para cada variável e correlação entre variāveis e \% C. $(\Delta .05=$ DMS de Tukey; n.s. = não significativo ; *=significativo a $5 \%$ e $* *=s i g n i f i c a t i v o$ a 1 \%) ..

19 - Efeito do teor de matéria orgânica na evaporação da āgua do horizonte B2 do Latossolo Roxo (grama de água por vaso). Dados referentes à: média de 3 repetições $(\bar{x})$, data da irrigação e quantidade de água adicionada para manter os tratamentos com teor de àgua estipulado, resultados da análise estatística para cada variāvel e correlação entre variáveis e o C. $(\Delta .05=$ DMS de Tukey; n.s. = não significativo; * = significativo a $5 \% \mathrm{e}^{* \star}=$ significativo a 1 \%) $\ldots \ldots \ldots \ldots \ldots \ldots \ldots \ldots \ldots$ 
20 - Efeito do teor de matéria orgânica na evaporação da água do horizonte Al do Podzólico Ver melho-Amarelo (grama de água por vaso). Dados referentes à: média de 3 repetições $(\bar{x})$, data da irrigação e quantidade de água adicionada para manter os tratamentos com teor de água estipulado, resultados da análise estatística para cada variável e correlação entre variáveis e $\%$ C. $(\Delta .05)=$ DMS de Tukey; n.s.=não significativo; $*=$ significativo a $5 \% ; *$ = significativo a 1 \%) $\ldots \ldots \ldots \ldots \ldots \ldots \ldots \ldots \ldots \ldots \ldots \ldots$

21 - Efeito do teor de matēria orgânica na evaporação da água do horizonte A2 do Podzólico Ver melho-Amarelo (grama de água por vaso). 'Dados referentes à: média de 3 repetições $(\bar{x})$, data da irrigação e quantidade de água adicionada para manter os tratamentos com teor de água estipulado, resultados da análise estatística para cada variável e correlação entre variáveis e \& $C(\Delta .05=$ DMS de Tukey; n.s = não significa tivo; $*$ = significativo a $5 \%$. e $* *$ = significativo a $\left.1 \frac{\circ}{0}\right) \ldots \ldots \ldots \ldots \ldots \ldots \ldots \ldots \ldots \ldots$ 
22 - Efeito do teor de matéria orgânica na evaporação da água do horizonte B2 do Podzólico Ver melho-Amarelo (grama de água por vaso) .Dados referentes à:mëdia de 3 repetiçōes $(\bar{x})$,data da irrigação e quaintidade de ạgua adicionada para manteros tratamentos com teor de água estipulado, resultados da análise estatística para cada variável e correlação entre variáveis e \& C. $(\Delta .05=$ DMS de Tukey; n.s = não significativo; * = significativo a $5 \% e^{\star *}=$ significativo a 1 \%) ..........

23 - Efeito do teor de matéria orgânica na produção de matéria seca numa cultura de painço (Seta lia italica Beauv), nos horizontes Ap e B2 do Latossolo Roxo, Al, A2 e B2 do Podzólico Vermelho Amarelo. Dados referentes à: média de 3 repetições, resultados da análise estatística para cada variável e correlação entre variáveis e teor de matéria seca e teor de carbono ( 8 C). $(\Delta: .05=$ DMS de Tukey; $a=$ coeficiente linear ; $\mathrm{b}=$ coeficiente angular; $\mathrm{r}^{2}=$ coeficiente de determinação; n.s = não significativo; * =significativo a $5 \% \mathrm{e}^{* *}=$ significativo a $1 \frac{8}{8}$ ).. 
24 - Efeito do teor de matéria orgânica na produção de matéria verde numa cultura de painço ISetalia italica Beauv), nos horizontes Ap e B2 do Latossolo Roxo, Al, A2 e B2 do Podzólico Ver melho-Amarelo. Dados referentes à: média de 3 repetições, resuitados da análise estatística para cada variável, correlação entre variáveis e teor de matéria verde e teor de carbono ( $8 \mathrm{C})$. ( $\Delta .05=$ DMS de Tukey; $a=$ coeficiente linear; $\mathrm{b}=$ coeficiente angular; $\mathrm{r}^{2}=$ coeficiente de determinação; n.s = não significativo; * = significativo a $5 \%$ e $* *$ = significativo a $1 \frac{8}{6}$ ). 
1 - Teor de carbono ( $\frac{\circ}{8}$ ) e de matéria orgânica (\%) no horizonte Ap do Latossolo Roxo após o perído de incubação e em relação à matéria orgâni-

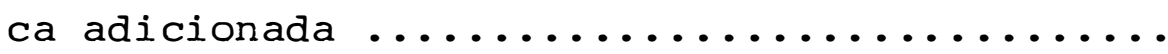

2 - Teor de carbono (\%) e de matéria orgânica no horizonte B2 do Latossolo Roxo após o período de incubação e em relação à matéria orgânica adicionada $\ldots \ldots \ldots \ldots \ldots \ldots \ldots \ldots \ldots$

3 - Teor de carbono (\%) e de matéria orgânica no horizonte Al do Podzólico Vermelho-Amarelo após o período de incubação e em relação à matéria orgânica adicionada ..............

4 - Teor de carbono (\%) e de matéria orgânica no horizonte A2 do Podzólico Vermelho-Amarelo após o período de incubação e em relação à matéria orgânica adicionada ...............

5 - Teor de carbono (\%) e de matéria orgânica no horizonte B2 do Podzólico Vermelho-Amarelo após o perỉodo de incubação e em relação à matéria orgânica adicionada $\ldots \ldots \ldots \ldots \ldots \ldots$. 
Pāgina

6 - Teores de areia e de limo determinado no horizonte Ap do Latossolo Roxo após o período de incubação e em relação ao teor de carbono dos tratamentos após o período de incubação ......

6a- Teor de potássio $(K)$ em relação ao \& $C$ após 0 perỉodo de incubação da matéria orgânica adi -

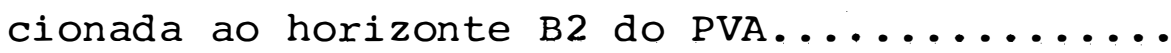

7 - Teor de areia no. horizonte B2 do Latossolo Roxo após o período de incubação e em relação à matéria orgânica adicionada ............

8 - Teor de limo determinado no horizonte Al do Podzólico Vermelho-Amarelo após o perỉodo de incubação e em relação à matéria orgânica adicionada..$\ldots \ldots \ldots \ldots \ldots \ldots \ldots \ldots \ldots \ldots$

9 - Teores de areia, limo determinado e argila no horizonte A2 do Podzólico Vermelho-Amarelo após o perỉodo de incubação e em relação à matéria

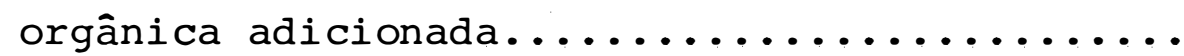

10 - Teores de areia e limo determinado no horizonte B2 do Podzólico Vermelho-Amarelo após o perỉodo de incubação e em relação à matéria or-

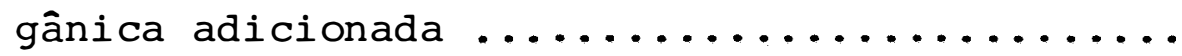

11 - Efeito do teor de matéria orgânica no teor de água em que a densidade do solo foi determinada.. 
12 - Densidade do solo (Ds) e densidade das partículas (Dp) em relação ao : C após o período de incubação da matéria orgânica adicionada ao ho-

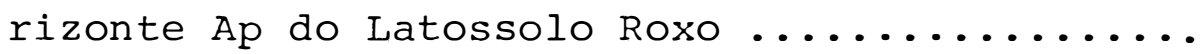

13 - Densidade do solo (Ds) e densidade das partículas (Dp) em relação ao : C após o período de incubação da matéria orgânica adicionada ao ho-

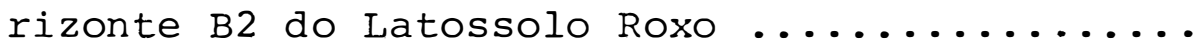

14 - Densidade do solo (Ds) e densidade das partículas (Dp) em relação ao oc após o período de incubação da matéria orgânica adicionada ao horizonte Al do Pođzólico Vermelho-Amarelo ........

15 - Densidade do solo (Ds) e densidade das partículas (Dp) em relação ao : C após o período de incubação da matéria orgânica adicionada ao horizonte A2 do Podzólico Vermelho-Amarelo.......

16 - Densidade do solo (Ds) e densidade das partículas (Dp) em relação ao : C após o período de incubação da matéria orgânica adicionada ao ho rizonte B2 do Podzólico Vermelho-Amarelo ...... 
17 - Curvas características de retenção de água para amostras do horizonte Ap do Latossol Roxo, mostrando o efeito da quantidade de matéria orgânica aplicada nos diversos tratamentos .....

18 - Curvas características de retenção de água para amostras do horizonte B2 do Latossol Roxo, mostrando o efeito da quantidade de matéria orgânica aplicada nos diversos tratamentos .....

19 - Curvas características de retenção de água para amostras do horizonte Al do Podzólico Vermelho-Amarelo, mostrando o efeito da quantidade de matéria orgânica aplicada nos diversos

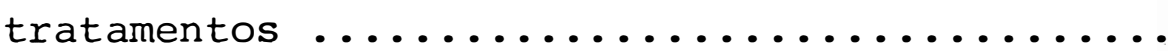

20 - Curvas características de retenção de água para amostras do horizonte Az do Podzólico Ver melho-Amarelo, mostrando o efeito da quantidade de matéria orgânica aplicada nos diversos

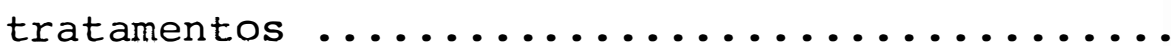

21 - Curvas características de retenção de água para amostras do horizonte B2 do Podzólico Vermelho-Amarelo, mostrando o efeito da quantidade de matēria orgânica aplicada nos diversos

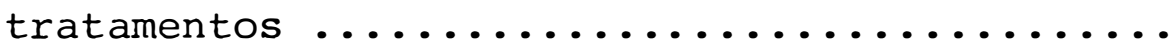


22 - Gramas de matéria verde (m.v) e gramas de matéria seca (m.s) em 10 plantas por vaso, em relação ao \& C, após o período de incubação da matéria orgânica adicionada ao horizonte Ap do

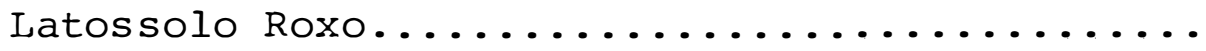

23 - Gramas de matéria verde (m.v) e gramas de matéria seca (m.s) em 10 plantas por vaso, em relação ao : C, após o período de incubação da matéria orgânica adicionada ao horizonte B2 do

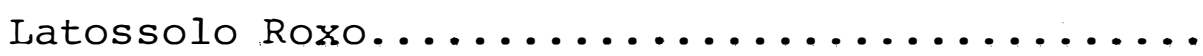

24 - Gramas de matéria verde (m.v) e gramas de matēria seca (m.s) em 10 plantas por vaso, em relação ao \& C, após o período de incubação da matéria orgânica adicionada ao horizonte Al do

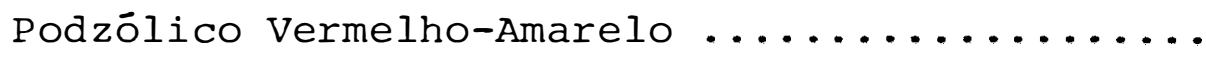

25 - Gramas de matéria verde (m.v) e gramas de matéria seca (m.s) em 10 plantas por vaso, em relação ao : C, após o período de incubação da matéria orgânica adicionada ao horizonte A2 do Podzölico Vermelho-Amarelo ................ 
xvii.

Página

26 - Gramas de matéria verde (m.v) e gramas de matéria seca (m.s) em 10 plantas por vaso, em relação ao \& C, após o período de incubação da matéria orgânica adicionada ao horizonte B2 do

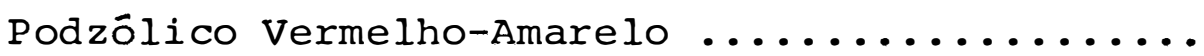


EFEITO DA MATERIA ORGANICA EM ALGUNS ATRIBUTOS DO SOLO.

Candidato: MILTON PAULINO DA COSTA

Orientador: Prof.Dr. Zilmar Ziller Marcos

RESUMO

Estudou-se a influência de seis teores de matéria orgânica incorporada a amostras de dois horizontes de um Latossolo Roxo (LR), série Iracema, e três horizontes de um Podzólico Vermelho-Amarelo (PVA), série Quebra-Dente, durante e após o período de incubação. Para isso, foi desenvolvido um experimento em condições de laboratório, em vasos, com o objetivo de estudar as variações em alguns atributos dos solos e quantificá-los.

Foi medida, durante o período de incubação, a evaporação da água do solo, correspondente ao peso de água adicionada aos tratamentos. Após o período de incubação, verificou-se os efeitos provocados pela decomposição da matēria orgânica em alguns atributos químicos: liberação de elementos essenciais e as variações na CTC, soma de bases,pH e teor de alumínio. Verificou-se, também, após a sua decom - 
posição, os efeitos direto e indireto da matéria orgânica na granulometria, na densidade do solo, na densidade das particulas e na capacidade de retenção de água no solo a diferentes potenciais.

Após a análise e interpretação dos resultados, constatou-se que a matéria orgânica apresentou comportamen tos diferentes para as duas séries de solos. A participação dos efeitos direto e indireto da matéria orgânica foi veri ficada na granulometria, na capacidade de retenção de agua no solo, e na densidade do solo. Na densidade das partículas foi constatado apenas o efeito direto da matéria orgânica. 
EFFECT OF ORGANIC MATTER IN SOME SOIL ATTRIBUTES.

Candidate: MILTON PAULINO DA COSTA

Adviser: Prof.Dr. Zilmar Ziller Marcos

SUMMARY

Six levels of organic matter added to samples taken from the main horizons (Al and B2) of two soil series occurring in the Piracicaba municipality, SP, namely "Iracema" (Roxo Latosol) and "Quebra-Dente" (Red-Yellow Podzolic), were studied as to their effect on some selected soil attributes following a 30-day incubation period. The study was conducted under laboratory conditions.

Quantitative measurements were taken of soil water evaporation, particle size distribution, release of nutrients, cation exchange capacity, soil solution pH, bulk density, particle density, and soil water retention curves.

The study was carried out so as to demonstrate both the direct and indirect effects of organic matter on the above mentioned soil attributes. 
4 .

1. INTRODUÇÃO

Embora altamente importante nos solos, a matéria orgânica representa uma fração muito pequena do peso total dos solos minerais, variando de menos de $1 \%$, em solos arenosos e de deserto, até 12 \& ou mais em solos de pradarias. Os solos arenosos apresentam, em geral, teores mais baixos de matéria orgânica do que os solos argilosos e não exibem, originalmente, uma cobertura vegetal exuberante. Nas regiões tropicais, onde a alta precipitação é acompanhada por elevada temperatura, esses solos têm melhor aeração, o que favo rece uma decomposição mais rápida da matéria orgânica; apresentam uma baixa retenção de água acompanhada de uma perda de cátions por lixiviação. As consequências são: solos com baixo teor de matéria orgânica e maior acidez na camada arável. 
A matéria orgânica representa uma fonte importante de nutrientes essenciais ao bom desenvolvimento vege tal. E constitui, ao mesmo tempo, um fator determinante de um grande número de características e propriedades físicas e químicas do solo.

Algumas pesquisas têm sido desenvolvidas em solos das regiões tropicais com o objetivo de estudar as variações em certos parâmetros físicos, em função do nỉvel de matéria orgânica no solo. Há, entretanto, necessidade de mais estudos, particularmente para se obter relações numéricas e expressões quantitativas desses efeitos.

O presente trabalho foi conduzido no labora tório de Física do Solo da Escola Superior de Agricultura "Luiz de Queiroz", com o objetivo específico de estudar as variações na densidade do solo (Ds), na densidade da partí cula (Dp) e na porosidade total ( $\frac{\xi}{\sigma}$ ), pela adição de dife rentes niveis de matéria orgânica a amostras tomadas de horizontes de duas séries de solos que ocorrem em Piracicaba, S.P.: Série Iracema (Latossolo Roxo) e Série Quebra-Dente (Podzólico Vermelho-Amarelo).

Procurou-se examinar, tambēm, as variações causadas na evaporação da água do solo durante um período de 
30 dias, na retenção de água da amostra a vārios potenciais (atm) e na liberação de nutrientes após a mineralização da matéria orgânica no solo. 
2. REVISÃO DE LITERATURA

A matéria orgânica tem influência direta e/ou indireta sobre os atributos do solo, provocando nítidas modificações nas características e propriedades físicas e químicas, isoladamente ou, como geralmente ocorre, em conjunto. A capacidade de troca de cátions, também chamada de C.T.C. efetiva, e a soma de bases, são aumentadas pela sua minera lização e posterior liberação de cátions e ânions, trocáveis e adsorvidos pelos colóides do solo.

Alēm da sua importância na liberação de cátions e ânions trocáveis, a matéria orgânica afeta a estru tura do solo, favorecendo a sua aeração e aumentando a capacidade de retenção de água. Além disso, com a alteração da estrutura, a densidade do solo é diminuída, favorecendo a exploração de maior volume de solo pelas raízes das plantas. 
A questão da matéria orgânica e seus efeitos no solo, têm sido considerados como diferentes quando se comparam solos de regiões temperadas e tropicais. Diversos autores, ao abordarem o assunto, ressaltam o fato de que essas diferenças são mais qualitativas que quantitativas. SANCHEZ (1976), por exemplo, afirma que a distribuição do carbono orgânico no perfil do solo, devido à vegetação nativa , é essencialmente a mesma nas regiọes tropicais e temperadas.

Algumas das particularidades dessas duas regiões, quanto à decomposição da matéria orgânica, foram relatadas por ALLISON (1957) da seguinte maneira: "Sob condi ções não saturadas, a temperatura e a umidade são os fatores que determinam a taxa de decomposição da matéria orgânica nos solos das regiões temperadas. Nos trópicos isto não é sempre evidente por causa da pobre aeração em solos de áreas sujeitas a fortes precipitações periódicas e/ou contínuas. Também, a ausência de destruịdoras geadas e os efeitos alternativos de umidade e seca, associados ao aumento da taxa de oxidação, contribuem para modificar esta situação". Consequentemente , considerando que as acumulações de matéria orgânica ocorreriam em ambas as regiões, temperada e tropical, as acumu lações são provavelmente muito mais acentuadas nas regiões úmidas tropicais, particularmente onde os níveis de água são variāveis. 
Estas duas posições, aparentemente contradi tórias, ressaltam o fato de que as condições de decomposição è que são marcadamente diferentes.

Pode-se acrescentar que, ainda que se discuta sobre essas semelhanças ou diferenças, a importância da matéria orgânica no solo é universalmente reconhecida. STURGIS (1957), por exemplo, observou que um dos maiores problemas relativos ao manejo da cultura de arroz, em solos alagados é manter o nỉvel de matéria orgânica. A importância fundamen tal desta prática é destacada por DAUIDSON (1975) ao afirmar que a matéria orgânica no solo, associada com a atividade de microrganismos, desempenha um importante papel na disponibilidade de íons minerais para as plantas.

Devido a ocorrência da decomposição da maté ria orgânica, acelerada pelas práticas de cultivo, resulta que, para a manutenção dos seus benefícios, é necessário repor, periodicamente, resíduos vegetais ao solo. De fato, ALLISON (1973) afirmou que, sob condições ambientais estabilizadas, tanto no solo virgem como no cultivado, eventualmente se estabelece um nível aproximadamente constante de matéria orgânica. Este estado de equilíbrio é alcançado quando as perdas de carbono, principalmente como dióxido de carbono, , equilibram o ganho que advém da adição de material vegetal. 
Uma amostra do que a literatura registra sobre esses efeitos é apresentada a seguir com 0 intuito de destacar que as informações provenientes das regiões tempe radas são de caráter tanto qualitativo quanto quantitativo, enquanto que os dados nacionais são predominantemente qualitativos.

2.1. Efeito da matéria orgânica nos atributos químicos

Sabe-se que os efeitos denominados químicos, da matéria orgânica no solo, ocorrem em função da sua decomposição. Segundo SAMPAIO e SALCEDO (1982): "A decomposição de restos de cultura, com a consequente mineralização de $N$, $S, P$ e outros elementos, é parte da ciclagem de nutrientes e, em solos tropicais de baixa fertilidade essa ciclagem é indispensável à manutenção da produtividade" do sistema. Essa decomposição tem sido acompanhada através de diversos métodos (ver GRISI, 1978; SANTOS, 1979 e outros).

Tal processo, também conhecido como mineralização da matéria orgânica, tem grande influência na agricultura o que é indicado pelo número de trabalhos que tratam do assunto. POTTKER e:TEDESCO (1979) mostraram que a liberação de $\mathrm{N}$ disponível no solo está relacionada com a matéria orgânica e com o teor de $\mathrm{N}$ total, e ocorre com maior inten - 
sidade entre 3 e 6 semanas de incubação. De acordo com GUPTA e REUSZER (1967), a mineralização da matéria orgânica maior nos primeiros períodos de incubação devido à presença de compostos orgânicos de fácil decomposição.

Um dos efeitos mais marcantes é a contribui ção da matéria orgânica para a capacidade de troca de cátions. Segundo PAIVA NETO (1942), a matéria orgânica constitui de 1 a 30 \% do solo, dependendo, essa quantidade, dire tamente da granulometria do solo. Esse autor, assinala, ainda, que a capacidade de troca de cátions dos solos vermelho-amarelo, podzólicos e latossólicos, em geral tendo dominância de caolinita e óxidos de ferro e alumínio, é de 2,3 a 40 e.mg/100 g de terra fina seca a $105-110^{\circ} \mathrm{C}$. Daqueles dados infere-se que outros colóides, além da caolinita, concorrem também para o fenômeno. A matéria orgânica, pela alta capacidade de troca de suas frações, 116 a 382 zmeq/100 g de material, segundo MC George, citado por WAKSMAN (1938), deve ser responsável, em grande parte, pela capacidade de troca de cátions.

Nos solos argilosos a C.T.C. da matéria organica representa de 30 a 40 \& do total e nos solos arenosos de 50 a $60 \%$. 
Segundo VAN RAIJ (1969), a contribuição da matéria orgânica à capacidade de troca de cátions em horizontes de superfície ( 21 amostras) foi de 74 . Esses resulta dos foram mais altos que os relatados por BAVER (1930) (30 a $608)$.

\subsection{Efeito do teor de matéria orgânica na granulometria}

A destruição da matéria orgânica por oxidação é uma prática muito comum como pré-tratamento de amostras de terra para a análise granulométrica.

Diversos trabalhos são encontrados na literatura sobre os métodos empregados para a remoção do material orgânico. O agente mais comumente usado é a água oxigenada $\left(\mathrm{H}_{2} \mathrm{O}_{2}\right)$, cujo efeito não é total. VERDADE (1954) pesquisou diversos solos com ampla variação de granulometria e verificou que a $\mathrm{H}_{2} \mathrm{O}_{2}$ nunca destroi completamente a matéria orgânica . Para solos desde arenito até turfa, verificou que era possível obter uma destruição desde 59 \& até 94 \& do total da matéria orgânica.

Outro agente oxidante, o hipoclorito de sódio,foi, recentemente, sugerido por ANDERSON (1963). Para o uso deste agente químico, esse autor recomenda: $5 \mathrm{~g}$ de solo $+10 \mathrm{ml}$ 
de NaOCl $(\mathrm{pH} 9,5)$ colocados em tubo de centrífuga de $100 \mathrm{ml}$, aquecidos, em seguida, em banho-maria durante 15 minutos e decantados após a centrifugação. Esse tratamento deve ser repetido, no mínimo, três vezes.

Segundo LAVKULICH e WIENS (1970), o pré-tra tamento com agente químico para a destruição da matéria orgânica deve ocasionar o mínimo de alterações na fração inorgânica. Verificaram, também, que o hipoclorito : de sódio (NaOCl) é mais eficaz que a $\mathrm{H}_{2} \mathrm{O}_{2}$ na oxidação da matéria orgânica sem, contudo, provocar alteração nas frações inorgânicas. Quando previamente ajustado a pH 9,5 já fornece o sódio ( $\mathrm{Na}$ ) necessário para a obtenção da dispersão dos colóides da amostra.

A destruição da matéria orgânica é feita para eliminar sua influência nos resultados da análise granulométrica. Esta interferência é, principalmente, de dois tipos.

Primeiramente considere-se que a matéria or gânica contribui para a agregação das partỉculas minerais do solo. Diversos pesquisadores mostraram, em seus trabalhos, o efeito da matéria orgānica na agregação do solo e na estabilidade da estruturalBAVER e HALL, 1937; GROHMANN, 1966; FREIRE, 1967; BUCKMAN e BRADY, 1967 e outrosl. 
Tais fatos foram comprovados por Baver (1935), citado por BAVER (1956), que observou uma correlação signi ficante $(0,687)$ entre as porcentagens de agregados maiores que $0,1 \mathrm{~mm}$ e o teor de carbono de vários solos. Essa correlação foi maior que a encontrada para agregados maiores que $0,05 \mathrm{~mm}$, o que indica a ação da matéria orgânica na formação de grandes agregados estáveis. No mesmo trabalho, alta correlação foi verificada entre matéria orgânica e agregação em solos que contém menos que $25 \%$ de argila.

O mecanismo da ação da matéria orgânica, na formação de agregados, foi estudado por GREENLAND (1965a) , que mostrou, com seus tratamentos, que os mecanismos da interação entre moléculas grandes estão relacionados às forças de Van der Waals e são importantes para as ligações húmus-minerais.

Posteriormente, GREENLAND (1965b) verificou a existência de ligações efetuadas por polissacarídeos, tanto como uma linha de ligação (novelo) quanto como películas de revestimento em torno de partículas que já se encontram próximas umas das outras. Segundo ALEXANDROVA (1960), a agregação de mineral e húmus está presente devido às forças de Van der Waals, cuja ação é favorecida pela desidratação que promove a aproximação das partículas. . 
De pesquisas feitas em solos chernozem, pod-zólico e Krasnozem, ALEXANDROVA et alii (1964) verificaram que as substâncias húmicas estão, aparentemente, distribuídas sobre as superfícies coloidais de todos os solos na forma de filmes entrelaçados entre as partículas, e sua quantidade é determinada pelo tamanho desta superfície, antes de qualquer fator.

Em todas as frações prē-coloidais, o conteúdo relativo de hümus, em $1 \mathrm{~cm}^{2}$ de superfície, é muito maior e aumenta regularmente das frações menores para as maiores. E especialmente mais elevado na fração entre $250 \mu \mathrm{m}$ a $10 \mu \mathrm{m}$.

A ligação de substâncias húmicas com a argila forma agregados pela gradual coalescência durante o processo de desidratação; e os óxidos de ferro e aluminio são essenciais para que ocorra a ligação.

O segundo tipo de interferência diz respeito à simples presença da matēria orgânica. Investigações microscópicas feitas por ALEXANDROVA et alie 11964$)$ mostram que as substâncias húmicas aparecem como partículas discretas. Nas partículas menores de $10 \mu \mathrm{m}$ a 1 jum, as substâncias húmicas aparecem como filme sobre as mesmas. 
Nos estudos sobre a associação da matēria orgânica com as diversas frações granulomētricas, maior ênfase tem sido dada à associação entre matéria orgânica e argila. Diversos autores já têm se referido ao fato de que há poucos dados associando a matéria orgânica a outras frações. Estu dos feitos por BROERSMA e LAVKULICH (1980), em diversos solos com mais de 40 \% de areia e menos de 20 \% de argila, sobre a distribuição da matēria orgânica nas frações granulo métricas, mostraram que entre 40 e 60 \& da matéria orgânica total estava associada a fração silte fino. Em solos com 18\% de silte fino e 14 \% de argila grossa a maior quantidade de matēria orgânica (32 \%) estava associada à fração argila grossa. Na fração areia, a matéria orgânica aparecia como particulas discretas, além de películas que revestiam os grânulos. A quantidade de matēria orgânica associada a cada $\mathrm{cm}^{2}$ de cada fração granulomētrica foi quase constante, Entretanto, o peso total da matéria orgânica por $\mathrm{cm}^{2}$ aumentou com o diâmetro da partícula.

MC Keague (1971), citado por BROERSMA e LAUKULICH (1980), encontrou tambēm matēria orgânica presente como partículas discretas, alēm de filmes de substâncias húmicas revestindo grânulos de areia em solos com baixo teor de argila. 
Percebe-se do exposto que o efeito da matéria orgânica como partícula é de menor significado do que o seu efeito como material que promove a agregação.

Talvez possa ser dito que o efeito da granulometria no teor de matéria orgânica do solo seja mais marcante do que a recíproca. Segundo KIEHL et alii (1972), a medida que aumenta o teor da areia total do solo, diminuem os níveis de $C$ \& e $\mathrm{N} \%$, devido à interação entre temperatura e matéria orgânica. Com o aumento dos níveis de limo e argila, há elevação dos teores de $\mathrm{C} \%$ e $\mathrm{N} \%$ devido aos aumentos da água retida, da capacidade de troca do solo, da soma de bases, diminuição da aeração, efeitos na temperatura do solo e melhoria na capacidade de retenção de cátions trocáveis.

Todos esses efeitos concorrem para justificar a afirmação feita por ESCHNER et alii (1957) de que, prova velmente, o efeito mais importante da granulometria da camada superficial do solo esteja relacionado ao acúmulo de matéria orgânica. 
2.3. Efeito do teor de matéria orgânica na densidade do solo (Ds) e na densidade das partículas (Dp).

Sabe-se que a matéria orgânica tem influência nos comportamentos físicos do solo, e que sua participação é mais prolongada e significativa após a mineralização. Diversos trabalhos têm mostrado uma estreita correlação entre o teor de matéria orgânica e a densidade do solo. Com base em suas observações, CURTIS e POST (1964), SAINI (1966) e JEFFREY (1970), apresentaram evidências indicando que, em alguns solos não cultivados, a matéria orgânica tem um efeito marcante sobre a densidade, podendo ser usada para predizer o valor desta.

Tal influênçia foi estudada também por WILLIAMS (1970) em solos arados e gradeados. Esse autor concluiu, de seus experimentos, que 50 \& da variação na densidade do solo seriam explicados pela variação do conteúdo de carbono nas camadas superficiais do solo.

Assim como foi comentado anteriormente para a granulometria, os efeitos da matéria orgânica sobre as duas densidades do solo e sobre a porosidade, são, também, de dois tipos. Sua presença contribui para a densidade das partículas proporcionalmente ao seu teor no solo, e seu efeito agre- 
gante contribui para afetar a porosidade e, consequentemente, a densidade do solo. Esses parâmetros são estreitamente relacionados e interdependentes pois, como assinalam KIEHL et alii (1972),"para uma correta interpretação dos dados de'densidade aparente', é indispensāvel comparā-la com outras informações como a 'densidade real', distribuição de poros por tamanho, teor de matéria orgânica e grau de agregação".

Portanto, enquanto a matéria orgânica afeta a densidade das partículas pela sua simples presença, esta densidade das partículas, modificada pela matéria orgânica, afeta a densidade do solo juntamente com a própria matéria orgânica pelo seu efeito agregante. ESCHNER et alii (1957), por exemplo, informaram que "solos de textura fina apresentam menor densidade do que solos de textura grossa". Esta afirmativa está relacionada, logicamente, com a ação agregante da matéria orgânica no solo proporcionando maior porosidade total.

Segundo BAVER (1956), a variação na porosidade total é função do tamanho das partỉcuías e grau de agregação. A matéria orgânica favorece a formação de grandes agregados estáveis, conferindo ao solo maior porosidade total. BUCKMANN e BRADY (1967) apresentaram dados mostrando que solos $\because \mathrm{com}$ elevado teor de matéria orgânica podem ter sua porosidade total diminuída de $60 \%$ para $50 \%$ quando cultivados. 
Quanto à densidade das partículas, relacionada com a composição mineralógica e com o teor de matéria orgânica do solo, BOUMA e HOLE (1971) obtiveram um aumento na densidade das partículas em solos cultivados, pela redução do teor de matéria orgânica em consequência do cultivo.

A relação entre as densidades e a matéria orgânica do solo tem motivado pesquisadores que buscam equações que permitam prever aqueles parâmetros.

STEWART et alii (1970) apresentaram fórmulas matemáticas para prever os valores das duas densidades em função do teor de matéria orgânica e de constantes experimentalmente determinadas.

ADAMS (1973) relatou o efeito da matéria orgânica sobre a densidade do solo e sobre a densidade das partículas. Desse estudo, no qual as fórmulas de STEWART (1970) foram testadas, ADAMS (1973) apresentou duas equações que possibilitam prever, respectivamente, as duas densidades do solo a partir do teor e densidade da matéria orgânica. Todavia, segundo este mesmo autor, a estrutura do solo mascara a influência da matéria orgânica sobre a variação da densidade do solo. 
KIEHL (1979) apresentou, mais recentemente, estimativas baseadas em dados do Levantamento de Reconheci mento dos solos do Estado de são Paulo. O autor estudou correlações entre densidade do solo, densidade das partículas , teor de carbono e outras propriedades. Foi possível estabelecer para horizontes superficiais, de solos com B textural e B latossólico, equações de regressão, ao nível de 'l o de probabilidade.

2.4. Efeito do teor de matéria orgânica na retenção $\mathrm{de}$ āgua no solo a diferentes potenciais

A capacidade de retenção de água pelo solo é fortemente afetada pela matéria orgânica. Pesquisas desenvolvidas nessa área, em diversos países que apresentam clima e solo diferentes, constatam que esse relacionamento é universal.

No Brasil, pesquisas desenvolvidas por GROH MANN e MEDINA (1962) demonstraram que a maior retenção de água, na camada até $30 \mathrm{~cm}$ de profundidade de uma terra roxa legítima de mata, foi devida à matēria orgânica, cujos teores variavam desde 6,8 웅 na camada superficial até 0,8 웅 na camada mais profunda. Em terra roxa intensivamente cultivada, a retenção foi menor nas camadas superiores. Esta menor re- 
tenção foi considerada como mais influenciada pela variação da textura do que pelos teores de matéria orgânica. Os autores verificaram, também, que, quando há homogeneidade do perfil do solo em relação à textura, a influência da maté ria orgânica na retenção de água no solo é mais evidente.

Ao estudarem as características de retenção de água em alguns solos da Costa Rica, inclusivamente um Latossolo Roxo, GONZALEZ e GAVANDE (1969) concluiram que as diferenças encontradas entre as camadas superiores e infe riores foram devidas às variações nos percentuais de argila e de matéria orgânica. A partir de 0,2 atm houve maior retenção pela camada inferior $(+30 \mathrm{~cm})$.

Correlações altamente positivas foram verificadas por MACLEAN e YAGER (1972), para a fração limo e para - carbono orgânico, nas profundidades superficiais, e para a areia fina (I.S.S.S.) nas camadas profundas de alguns solos de Zambia.

Alto valor para a correlação entre textura, matēria orgânica e retenção de água foi observada por WINKLE e GOEDERT (1972), em solos Podzólicos e Gleizados, do Estado do Rio Grande do Sul. 


\section{CLAYTON e JENSEN (1973) encontraram, em solos} de Idaho (EUA), efeito secundário da textura do solo na retenção de água. Em contraste, a retenção foi grandemente afetada pelos teores de matéria orgânica. A variação da reten ção a $1 / 3$ bar de tensão foi explicada em 57 \& pela matéria orgânica e à 15 bar de tensão em 62 \&.

Estudos sobre a adsorção de água em solos Latossólicos e Podzólicos do Estado de São Paulo, realizados por GROHMANN e CAMARGO (1973), mostraram que a espessura da camada de água e o teor de água higroscópica são mais elevados, relativamente ao solo original, quando se destrói a matéria orgânica. Os autores consideraram que a matéria orgà nica estaria bloqueando posições na superfície de absorção da hematita e da goetita. Percebe-se que o efeito da matéria orgânica na retenção de água pode ser negativo.

SHETRON (1974) observou em solos arenosos sob floresta, no estado de Michigan (EUA), que os conteúdos de carbono orgânico e óxido de ferro livre têm maior efeito sobre a retenção de água no horizonte B2l do que a distribui ção do tamanho de partículas. No horizonte $C$, cujo teor de carbono é baixo, a retenção de água disponível è mais dependente dos óxidos de ferro livre e do tamanho de partículas. 
Estudando solos de pradaria da Inglaterra, HOLLIS et alii (1977) desenvolveram uma equação de regressão, utilizando matéria orgânica e granulometria para explicar a retenção de āgua desse solo. Verificaram que essa equação explicaria cerca de 57 \& da variação em água disponível e 77 \& da água retida a $0,05 \mathrm{~atm}$.

Os trabalhos desenvolvidos por SALTER e WIL LIAMS (1963), na Inglaterra, após aplicações anuais de esterco de curral, durante 8 anos consecutivos, demonstraram um significativo aumento na capacidade de água disponível de um solo barro-arenoso e também no volume de água liberada a baixas tensões. Isto indica o efeito da matéria orgânica na agregação que estabiliza a estrutura, a qual, por sua vez, afeta a retenção de água a baixas tensões, Estes mesmos auto res (1965) mostraram que os teores de água correspondentes à capacidade de campo e ponto de murcha permanente, avaliadas diretamente, aumentaram progressivamente dos solos arenosos para os argilosos. As variações nas características de umidade, dentro de uma classe textural, foram atribuídas não apenas a diferenças estruturais mas, também, a pequenas varia ções na granulometria e no teor de matéria orgânica.

SALTER e WILLIAMS (1967) apresentaram um mé todo para estimar capacidade de água disponível no campo. A 
importância e participação da matéria orgânica é reconhecida pelos autores ao verificarem que a equação proposta è adequada para camada arada com baixo teor de carbono. A estru tura e a matéria orgânica são consideradas fatores importantes juntamente com a granulometria. A contribuição da matéria orgânica para a estabilização da estrutura, através da agregação, torna-a um importante fator para a retenção de āgua a baixas tensões.

Trabalhos efetuados por SALTER et alii (1967), em um experimento utilizando esterco de curral, mostraram que as parcelas que receberam matéria orgânica, conquanto mantivessem aproximadamente a mesma capacidade de água disponível, tiveram valores menores de tensão, significando que libera vam maior quantidade de água para um pequeno acréscimo na tensão da matriz.

PETERSEN et alii (1968a) observaram, em solos da Pensylvania (EUA), associação de carbono orgânico com o teor de água retida a 15 atm, mas não com a retida a $1 / 3$ de tensão. A explicação dada pelos autores foi que a matéria orgânica favorece a agregação do solo e a formação de poros grandes, os quais retém pouca água a $1 / 3$ de atm. A capacidade da matéria orgânica em reter água acima de 15 atm, pode ser a explicação para que o teor de água a 15 atm aumente com 
o aumento da matéria orgânica. Em um trabalho posterior IPETERSEN et alii 19686), esses mesmos autores, estudando os fatores que afetam a retenção de água dentro da classe textural barro-limoso, verificaram que a retenção de água a 1/3 atm e 15 atm aumentou com o acréscimo de carbono orgânico.Este aumento não promoveu mudança na faixa de água disponível. Isto indica, segundo esses autores, que a adição de matéria orgânica em solos com textura mais fina que barro-limoso,não promoverá aumento significativo na água disponỉvel.

As observações de PETERSEN indicam que ' em baixas tensões a matéria orgânica tem um efeito indireto na retenção de água em decorrência de sua participação na agregação e, em altas tensões, tem uma participação direta pela sua elevada superfície específica e capacidade de adsorção.

Dias (1970), citado por FREIRE (1975), considera que a influência da matéria orgânica sobre a capacidade de água disponível é devida principalmente, à formação de microagregados do tamanho de limo.

REEVE et alii (1973) realizaram estudos : com solos da Inglaterra e do país de Gales e relataram que a retenção a 15 bar está associada à argila, enquanto que a re- 
tenção a baixas tensões ao conteúdo de matéria orgânica e à distribuição dos tamanhos de poros.

Estudos feitos por FREIRE 11975), em Latossolo Roxo de Minas Gerais, revelaram que a influência de ferro livre, argila e carbono não são semelhantes com relação à retenção de água. Quando o carbono contribui positi vamente os óxidos de ferro livre e argila contribuem nega tivamente, e vice-versa. O efeito do carbono é positivo abaixo de 0,02 atm e entre 0,1 atm, enquanto que o ferro livre e argila têm efeito positivo de 0,04 atm a 1,0 atm e entre 10 atm e 15 atm. FREIRE mostrou, também, que a remoção da matéria orgânica afetou mais a retenção de água na faixa abaixo de 0,06 atm para o horizonte Al e abaixo de 0,04 atm para 0 horizonte $\mathrm{B} 2$, indicando que o efeito da matéria orgânica é mais acentuado em baixas tensões.

HAMBLIN e DAVIES (1977) realizaram seus estudos em solos barrentos da Inglaterra. Verificaram que a retenção de água é maior em solos com alto teor de matéria orgânica humificada em comparação com solo de baixo teor. Mas, a diferença é mais pronunciada em tensões mais baixas (abaixo de pF 2). Verificaram haver uma redução da porosidade total com o aumento da tensão, indicando a ocorrência de contração. Os solos com teor maior de matéria orgânica ti- 
nham, em geral maior porosidade total em todas as tensões, 0 que revelou uma resistência a contração.

A sequência de comentários apresentados re vela que os efeitos da matéria orgânica do solo sobre a retenção de água não são constantes. Tais efeitos são, apa rentemente, variados em função do grau de decomposição da matéria orgânica e também da granulometria e natureza das partículas. Pode-se dizer que os trabalhos revistos indicam que quando ocorre o efeito agregante da matéria orgânica há, conjuntamente aumento da retenção de água nas tensões mais baixas.

\subsection{Efeito do teor de matéria orgânica na evaporação}

Não foi encontrado na literatura algum trabalho abordando,especificamente, o efeito da matéria orgânica na evaporação da água do solo. Entretanto, é tacitamente aceito que haja esse relacionamento, pois a literatura é farta em trabalhos que indicam a participação da matéria orgânica sobre a porosidade e sobre a superfície específica do solo. Assim é razoável supor que a taxa de evaporação da água seja afetada pela matéria orgânica, possivelmente numa relação direta. 
2.6. Comentārio final.

Tem-se, diante do exposto, uma configuração geral da participação da matéria orgânica em alguns aspectos do comportamento físico do solo. Os trabalhos relatados mostram que, fundamentalmente, a matēria orgânica contribui modificando a constituição física do solo pela sua simples presença. E contribui, tambēm, indiretamente, para a modi ficação e estabilização da estrutura que define uma parti cular distribuição de poros por tamanho. 


\subsection{Materiais}

Devido a ser este um trabalho sobre a influência da mineralização da matéria orgânica em alguns atributos do solo, utilizou-se, como critério para a escolha dos solos, o fato de, segundo a literatura, apresentaram diferentes composições granulométricas. E, para a escolha do material orgânico a ser incorporado, considerou-se dois materiais comumente usados na agricultura e um terceiro que, atualmente, representa um potencial futuro (ver item 3.1.2.).

3.1.1. Solos

Foram coletadas amostras dos horizontes Ap e B2 de um Latossolo Roxo (LR), de ocorrência no município de 
Piracicaba, classificado por RANZANI et alii (1960) como sērie Iracema, e amostras dos horizontea Al, A2 e B2 de um Podzólico Vermelho-Amarelo (PVA), tambēm de ocorrência em Piracicaba, classificado pelos mesmos autores como série Quebra-Dente. A escolha desses solos deve-se ao fato de apresentarem teores de argila, óxido de ferro e matéria orgânica,diferentes entre os seus respectivos horizontes e entre os mesmos horizontes de cada um deles. Esses dados são mostrados na Tabela 1.

Tabela 1 - Teores de carbono, argila e óxido de ferro das amostras utilizadas.

\begin{tabular}{lrrrrrr}
\hline \multirow{2}{*}{ Atributo } & \multicolumn{2}{c}{ LR } & & \multicolumn{3}{c}{ PVA } \\
\cline { 2 - 3 } \cline { 6 - 7 } & \multicolumn{1}{c}{ Ap } & B2 & & A1 & \multicolumn{1}{c}{ A2 } & \multicolumn{1}{c}{ B2 } \\
\hline C & 2,00 & 0,48 & & 1,12 & 0,50 & 0,36 \\
$\therefore$ argila & 68,90 & 74,66 & & 22,34 & 19,61 & 42,45 \\
$\therefore \mathrm{Fe}_{2}{ }^{0} 3$ & 21,10 & 18,00 & & 0,60 & 0,50 & 1,30 \\
\hline
\end{tabular}

As amostras dos horizontes Ap e B2, do Latossolo Roxo foram coletadas na estrada para Iracemápolis, va:riante da estrada de Piracicaba a Rio Claro, na meia encosta de um declive, face leste, de aproximadamente $10 \%$. As amos- 
tras dos horizontes Al, A2 e B2 do Podzólico Vermelho-Amarelo foram coletadas no bairro Pompéia, em Piracicaba, em terreno pertencente à Olaria Furlan, localizada, aproximadamente, a $3 \mathrm{~km}$ do cemitério municipal, na direção sudoeste.

Foram coletados cerca de $60 \mathrm{~kg}$ de terra de cada um dos horizontes escolhidos. As amostras foram colocadas em bandejas de alumínio, secadas à sombra, destorroadas e passadas em peneira de $2 \mathrm{~mm}$ de malha.

\subsubsection{Material orgânico}

Os materiais orgânicos usados neste experimento foram: Capim Colonião seco (Panicum maxima Jacq.), esterco de gado curtido ao ar, e bagaço de cana-de-açúcar parcialmente decomposto. Esses materiais foram separadamente secados ao ar, moidos, passados em peneira de 0,5 mm de malha e misturados na proporção de l:l:l a base de peso. Essa mistura constituiu a matéria orgânica usada para compor os tratamentos deste estudo. A Tabela 2 mostra os resultados da anālise química de cada um dos materiais orgânicos e da mistura preparada. Um exame detalhado dos dados dessa tabela mostra que a mistura na proporção $1: 1: 1$ foi conseguida. 


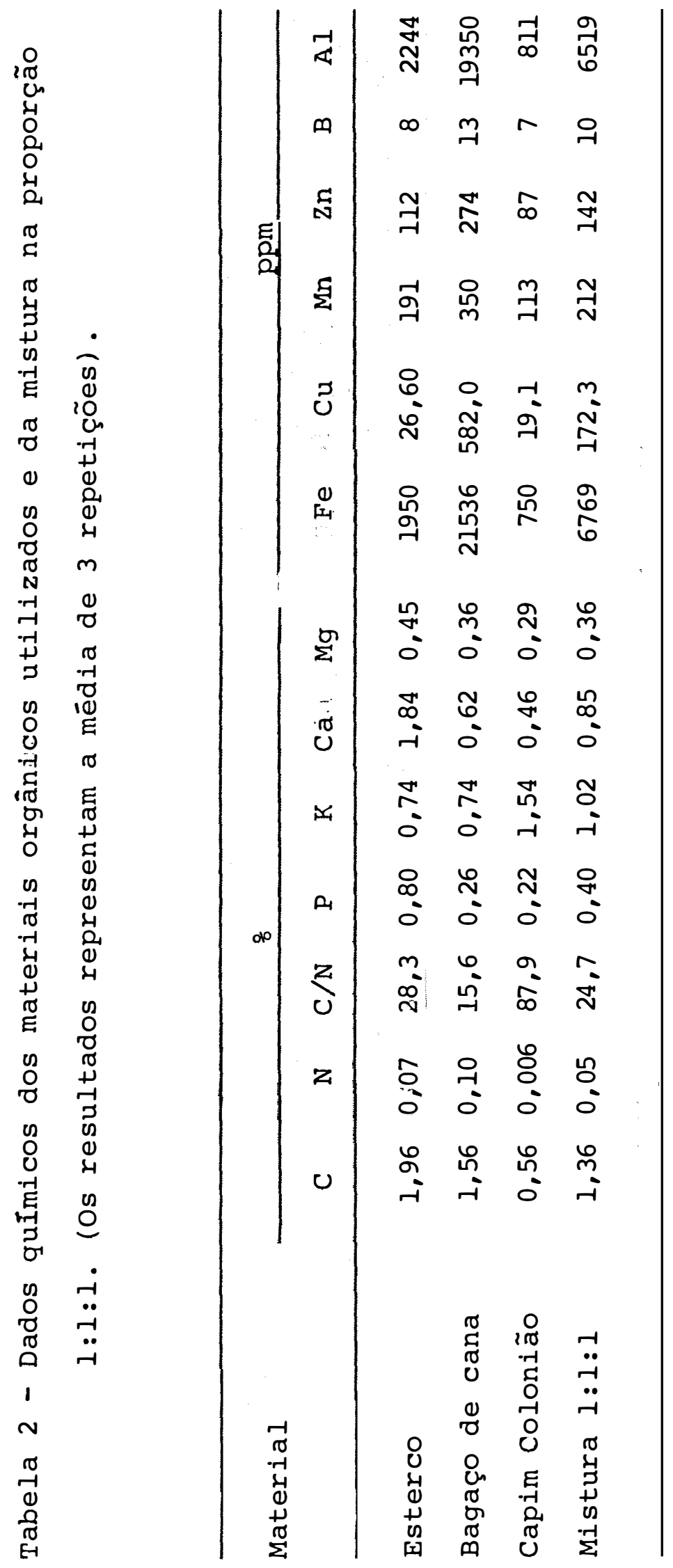




\subsection{Métodos}

Com o propósito de facilitar a compreensão, dividiu-se este ítem do trabalho em dois aspectos metodoló gicos inerentes à pesquisa científica. O primeiro aspecto diz respeito ao método de investigação do fenômento e o segundo aborda o aspecto operacional, relatando, descritivamente, as sequências de operações utilizadas para o levantamento de dados.

\subsubsection{Método experimental}

Neste trabalho utilizou-se o método empírico de experimentação. Doses crescentes de matéria orgânica, escolhidas com base em observações anteriores, registradas na literatura, foram aplicadas em amostras de terra para verificar seus efeitos sobre alguns atributos do solo. Esses efeitos foram medidos e avaliados segundo modelos estatísticos Para a interpretação dos resultados obtidos, utilizou-se de comparações entre os comportamentos dos horizontes e, também, de comparações dos dados obtidos com os dados esperados segundo as teorias em voga. Esta avaliação de relação :! causal entre a matéria orgânica e alguns atributos do solo seguiu o "Método da Variação Concomitante" de MILL (1843, reeditado, 
1967). Para as interpretações finais e conclusão do trabalho aplicou-se o método indutivo de argumentação.

3.2.2. Método operacional

\subsubsection{Montagem dos tratamentos}

A primeira etapa para a realização deste trabalho foi o preparo dos tratamentos. Para tanto, misturou-se terra dos horizontes escolhidos (ver item 3.1.1.) com a matéria orgânica (ver ítem 3.1.2.). Esta mistura foi feita de modo a obter, para cada horizonte, seis (6) níveis de matéria orgânica que correspondem aos tratamentos $0 \%, 2 \%, 4 \%$, $6 \%, 8 \%$ e $10 \%$ de matéria orgânica.

A terra de cada horizonte, assim preparada. , foi distribuída em vasos de plástico (formato troncônico) com 2 litros de capacidade. Colocou-se $1 \mathrm{~kg}$ de terra + matéria orgânica em um desses vasos,para cada tratamento dentro de cada horizonte, respectivamente. Esse procedimento foi repetido três vezes, de modo que se obteve 90 vasos preparados, correspondendo a seis tratamentos repetidos três vezes para cada um dos cinco horizontes. 
O trabalho completo constou de 6 experimentos desenvolvidos sobre esse material. Os experimentos foram conduzidos em sequência, mas os dados de cada experimento, para cada horizonte, foram analisados individualmente, segundo um delineamento experimental inteiramente casualizado com seis níveis de matéria orgânica, que correspondem aos tratamentos $0 \%, 28,48,6 \%, 8 \%$ e $10 \%$ de matéria orgânica, com 3 repetições para cada tratamento.

Os experimentos foram os seguintes:

1. Estudo sobre o efeito da matéria orgânica em alguns atributos químicos.

2. Estudo sobre o efeito da matéria orgânica na granulometria.

3. Estudo sobre o efeito da matéria orgânica na densidade do solo e na densidade das partículas.

4. Estudo sobre o efeito da matéria orgânica na retenção de água a diferentes potenciais.

5. Estudo sobre o efeito da matéria orgânica na evaporação da água do solo. 
6. Estudo sobre o efeito da matéria orgânica numa cultura de painço (Setalia italica, Beauv.), quanto aos aspectos evapotranspiração e crescimento.

3.2.2.2. Determinação do teor de água para irrigação dos tratamentos

Para determinar o teor de água a ser mantido em cada tratamento,durante o período de incubação,utilizou-se o método que simula o princípio da capacidade de campo,segundo MARCOS*(1981, não publicado) e denominado TSFM (torrão se parado pela frente de molhamento). Esse método consta do seguinte: coloca-se aproximadamente $150 \mathrm{~g}$ da amostra de terra (T.F.S.A.) numa cápsula de alumínio e, com uma pipeta, adiciona-se 2 cc de água destilada. Após 10 segundos retira-se 0 torrão úmido (separado da terra seca pela frente de molhamento) o qual é imediatamente pesado, obtendo-se assim o peso úmido (Pu). O teor de água do pequeno torrão é determinado gravimetricamente.

Este procedimento foi desenvolvido para amostra de todos os cinco horizontes, porém, apenas para os tratamentos 0 \% , 4 \% e 10 \% de matéria orgânica, conforme a Tabela 3. Os teores de água para os demais tratamentos, $2 \%, 6 \%$

* Comunicação particular. 
e 8 \& de matéria orgânica," foram obtidos por extrapolação dos valores da Tabela 3. O quadro completo dos teores de água é apresentado na Tabela 4.

Tabela 3 - Teores de água para os tratamentos $0 \%, 4 \%$ e $10 \%$ de matéria orgânica determinados pelo método TSFM (dados em \& de peso).

\begin{tabular}{|c|c|c|c|c|}
\hline \multirow{2}{*}{ Solo } & \multirow{2}{*}{ Horizonte } & \multicolumn{3}{|c|}{ Matēria orgânica } \\
\hline & & 0 & 4 & 10 \\
\hline \multirow[t]{2}{*}{ LR } & Ap & 39,82 & 42,73 & 46,78 \\
\hline & B2 & 43,15 & 46,79 & 51,72 \\
\hline \multirow[t]{3}{*}{ PVA } & Al & 24,77 & 28,47 & 37,11 \\
\hline & $\mathrm{A} 2$ & 22,82 & 26,96 & 36,02 \\
\hline & B2 & 29,18 & 36,19 & 45,07 \\
\hline
\end{tabular}

3.2.2.3. Incubação da amostra de terra

Este procedimento foi desenvolvido nos vasos plásticos, contendo a mistura de matérias orgânicas e T.F.S.A., previamente homogeneizada, conforme foi descrito no item 3.2 .2 .1 . 
Tabela 4 - Teor de água para o controle de irrigação de todos os tratamentos durante o período de incubação (teores extrapolados dos valores da Tabela 3 e expressos em $\&$ de peso).

\begin{tabular}{|c|c|c|c|c|c|c|c|}
\hline \multirow[t]{2}{*}{ Solo } & \multirow{2}{*}{ Horizonte } & \multicolumn{2}{|c|}{8} & \multicolumn{2}{|c|}{ Matēria } & \multicolumn{2}{|c|}{ orgânica } \\
\hline & & 0 & 2 & 4 & 6 & 8 & 10 \\
\hline \multirow[t]{2}{*}{ LR } & Ap & 40 & 41 & 43 & 44 & 46 & 47 \\
\hline & B2 & 43 & 45 & 47 & 49 & 50 & 52 \\
\hline \multirow[t]{3}{*}{ PVA } & Al & 25 & 26 & 28 & 31 & 34 & 37 \\
\hline & $\mathrm{A} 2$ & 23 & 25 & 27 & 30 & 32 & 36 \\
\hline & B2 & 29 & 32 & 36 & 39 & 42 & 45 \\
\hline
\end{tabular}

Os vasos foram irrigados de modo a colocar os tratamentos com os teores de água estipulados na Tabela 4. A quantidade de água evaporada em cada irrigação foi controlada por pesagem dos vasos para se obter o peso da água evaporada. A irrigação de todos os vasos foi sempre feita dentro de um intervalo de três horas. A primeira reposição de água evaporada foi feita dois dias após o início da incubação. As demais irrigações foram feitas a intervalos de três a quatro dias durante um período de 30 dias. o período de incubação foi de 23 de novembro a 23 de dezembro de 1981 . 
Terminado o período de incubação foi coletada, de cada vaso, com anel volumétrico, amostra de 30 cc para a determinação da densidade do solo. Para as demais determina ções analíticas foi coletado, de cada vaso, aproximadamente $200 \mathrm{~g}$ de terra. Essas amostras foram colocadas em bandejas de aluminio e deixadas secar ao ar dentro do laboratório de Física do Solo. Em seguida, as amostras foram destorroadas,passadas em peneira de $2 \mathrm{~mm}$ de malha e acondicionadas para aná lise.

Continuou-se com as irrigações controladas, a intervalos de 3 a 4 dias, na terra que permaneceu nos vasos, durante mais 50 dias (até 12 de fevereiro de 1982) com o propósito de observar por um período mais longo o efeito . dos tratamentos na evaporação da água do solo. Todas as reposi ções da água evaporada, com excessão das duas primeiras, foram registradas.

3.2.2.4. Coleta de dados e métodos analíticos

A obtenção de dados em ćada um dos experimen tos foi feita pela aplicação dos seguintes métodos analíticos.

a - As análises químicas do material orgânico incorporado aos tratamentos, executadas no Centro de Energia Nuclear na Agricultura (CENA), foram: 
- Carbono orgânico (C) por tiossulfatometria;

- Potássio (K) por fotometria de chama;

- Cálcio (Ca), Magnésio (Mg), Fósforo $\left(\mathrm{PO}_{4}\right)$ e Alumínio (Al) por espectrometria de emissão com plasma induzido de argônio;

- Nitrogênio total (N) por colorimetria pelo método do indol fenol azul.

b - As análises químicas para a caracteriza ção das amostras de terra dos 5 horizontes foram feitas no Laboratório de Fertilidade do Departamento de Solos, Geolo gia e Fertilizantes da ESALQ, segundo CATANI e JACINTO (1974).

$$
\text { c - A análise granulométrica foi executada }
$$

segundo método proposto por PAULETTO (1978), que utiliza a pipeta para a coleta da alíquota da suspensão preparada por agitação horizontal lenta de $5 \mathrm{~g}$ de quartzo grosso $(1,0 \mathrm{~mm}$ a $0,5 \mathrm{~mm})+15 \mathrm{ml}$ de $\mathrm{NaOH} 1 \mathrm{~N}+5 \mathrm{~g}$ de TFSE. As frações granu lométricas foram determinadas segundo a classificação do Departamento de Agricultura dos Estados Unidos (EUA, 1951).

$$
\text { d - A densidade do solo (Ds) foi determinada }
$$
pelo método do anel volumétrico de Kopecky, utilizando-se um anel com capacidade para conter uma amostra indeformada de $30 \mathrm{~cm}^{3}$. 
e - A densidade da partícula (Dp) foi determinada pelo método do picnômetro, utilizando-se um picnômetro de $50 \mathrm{~cm}^{3}$ e água destilada como fluido. o ar dissolvido na āgua foi parcialmente removido na mesma câmara de pressão subatmosférica (26 cm de $\mathrm{Hg}$ ) em que o ar adsorvido à terra foi removido.

f - A retenção de água pelos tratamentos estudados, nos potenciais correspondentes a 0,06 atm; 0,5 atm ; 1,0 atm; 3,0 atm e 15,0 atm, foi determinado segundo a meto dologia proposta por RICHARDS e FIREMAN (1943). 
Os resultados e discussão dos seis experimentos são apresentados na sequência em que foram realizados. Embora o sejam de maneira independente, estão interrelacio nados pelos tratamentos com teores crescentes de matéria orgânica. Os efeitos desses tratamentos, àvaliados durante e após o período de incubação, refletem, como um todo, a ação da matéria orgânica aplicada separadamente em horizontes das duas séries de solos estudados.

Os dados, experimentalmente obtidos,são apresentados em tabelas compactas para cada um dos cinco horizontes. E mostram, além dos valores médios de cada atributo,considerado em relação aos tratamentos, os parâmetros estatís ticos da análise da variância, do teste comparativo para médias segundo Tukey, e da regressão linear, relacionando os 
atributos ao teor de carbono determinado após o período de incubação.

4.1. Experimento 1: Efeito do teor de matéria orgânica em alguns atributos químicos do solo

As consequências da mineralização de ' níveis crescentes de matéria orgânica, adicionados às amostras dos horizontes Ap e B2 do Latossolo Roxo e Al, A2 e B2 do Podzólico Vermelho-Amarelo, são apresentadas nas Tabelas 5 a 9 , inclusive.

Verificou-se significativas modificações nos atributos químicos estudados em todos os horizontes. A comparação entre as médias dos tratamentos, através do teste de Tukey, mostra que o efeito da matéria orgânica provocou nítidas modificações nos atributos químicos em todos os tratamentos.

As modificações provoćadas pela mineralização da matéria orgânica no solo propiciaram um progressivo aumento da percentagem de carbono conforme aumentou o nível de matéria orgânica aplicada. Essa relação é claramente indicada pelos dados e ilustrada pelas Figuras 1, 2, 3, 4 e 5 . 0 


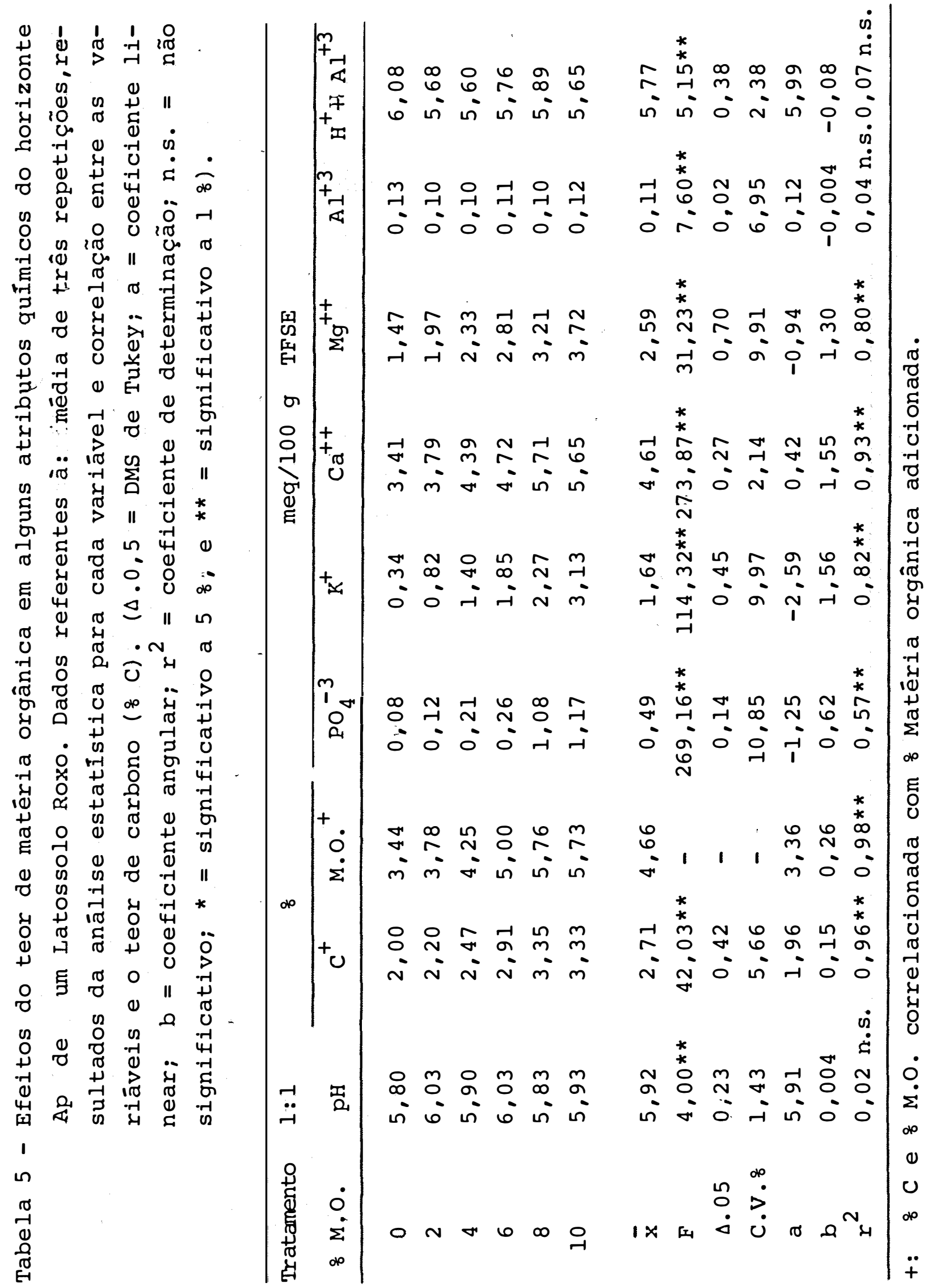




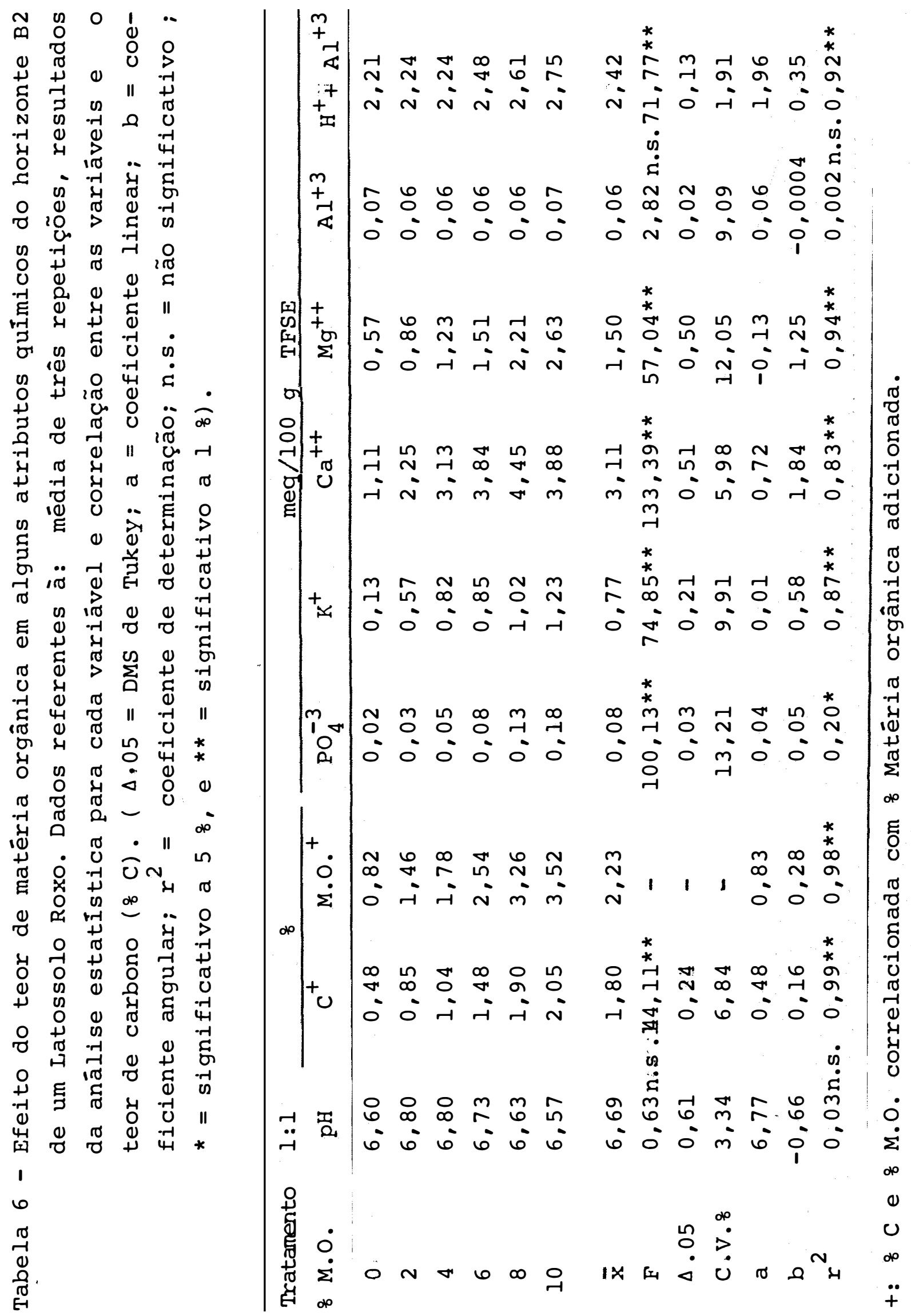




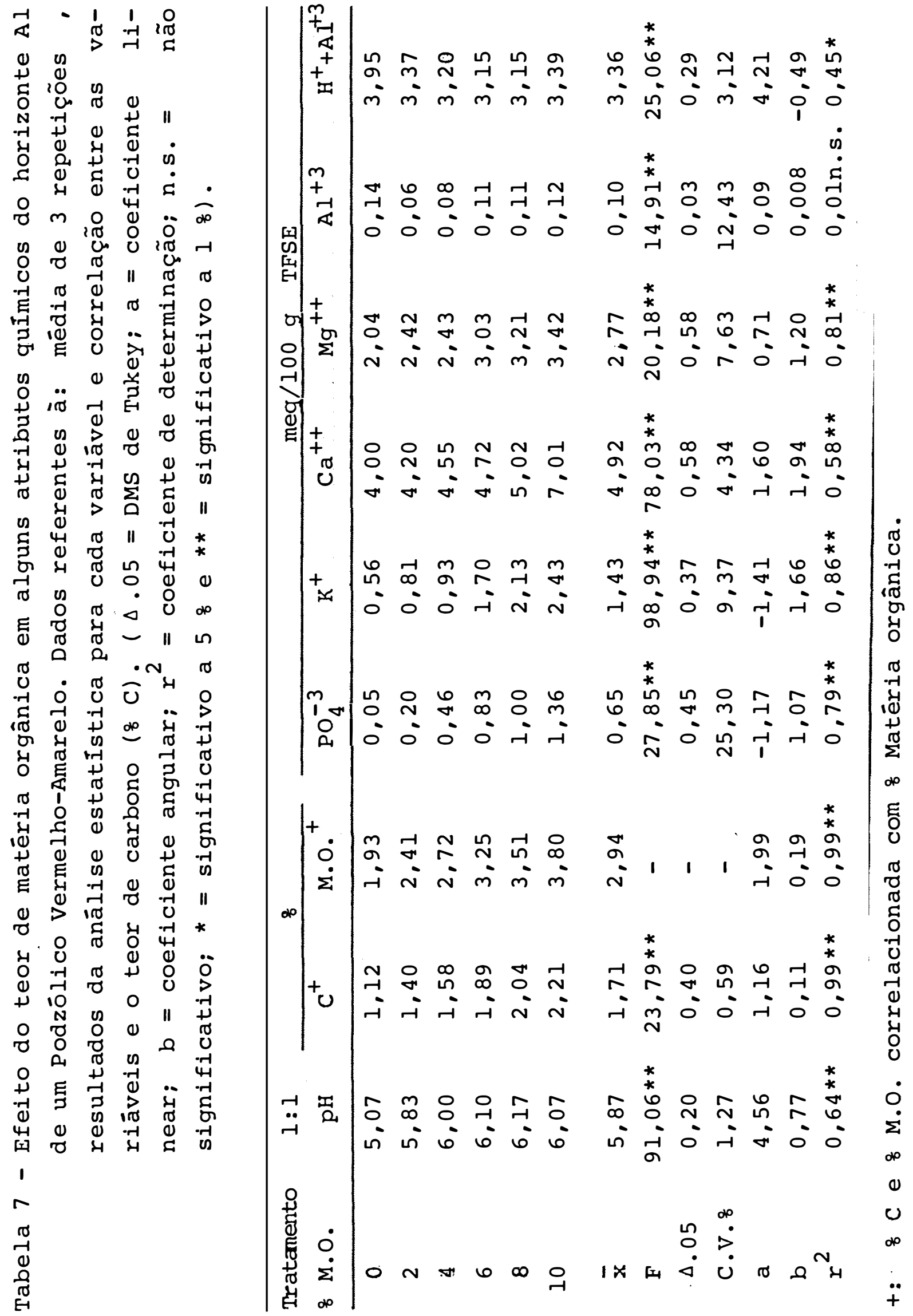




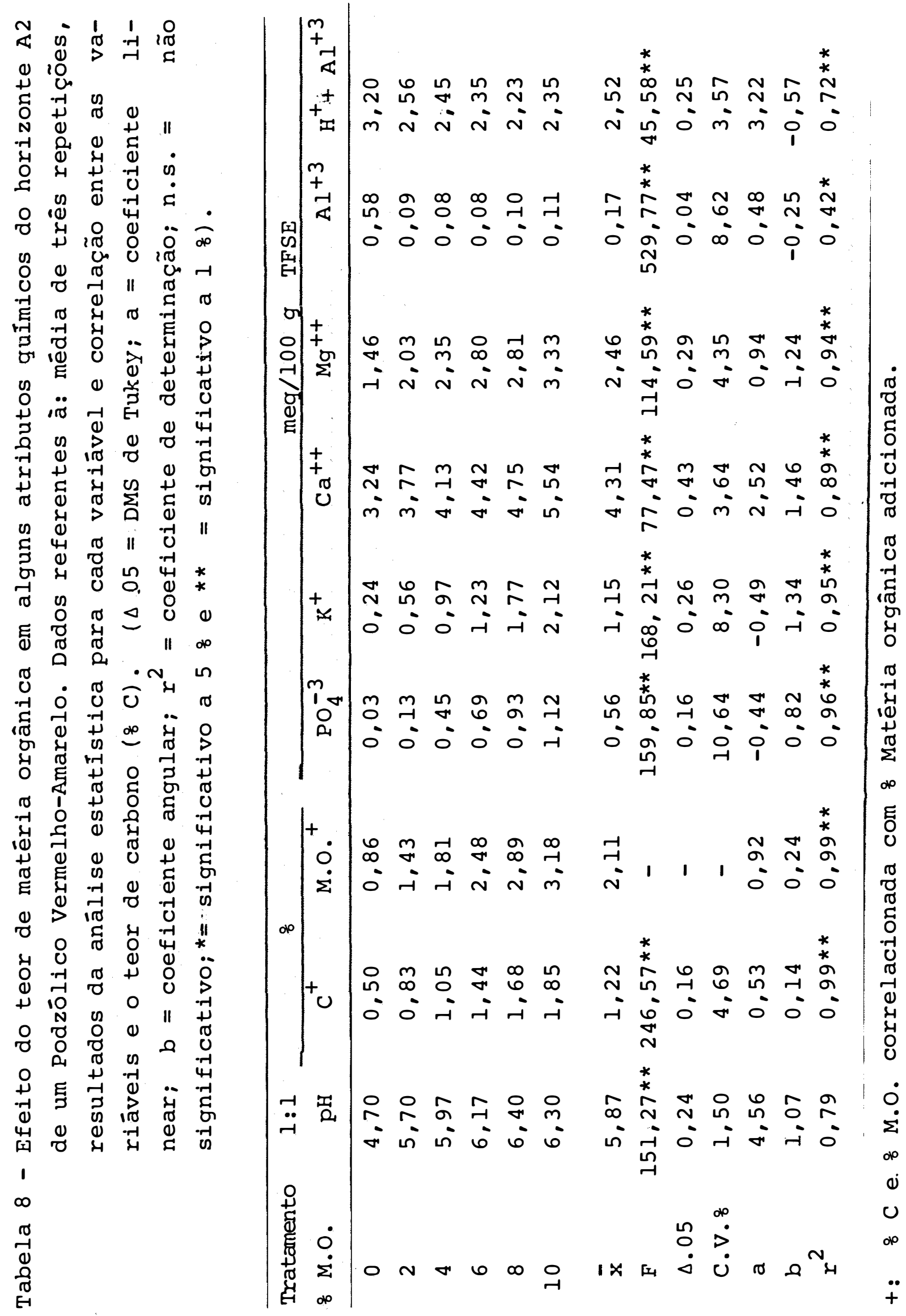




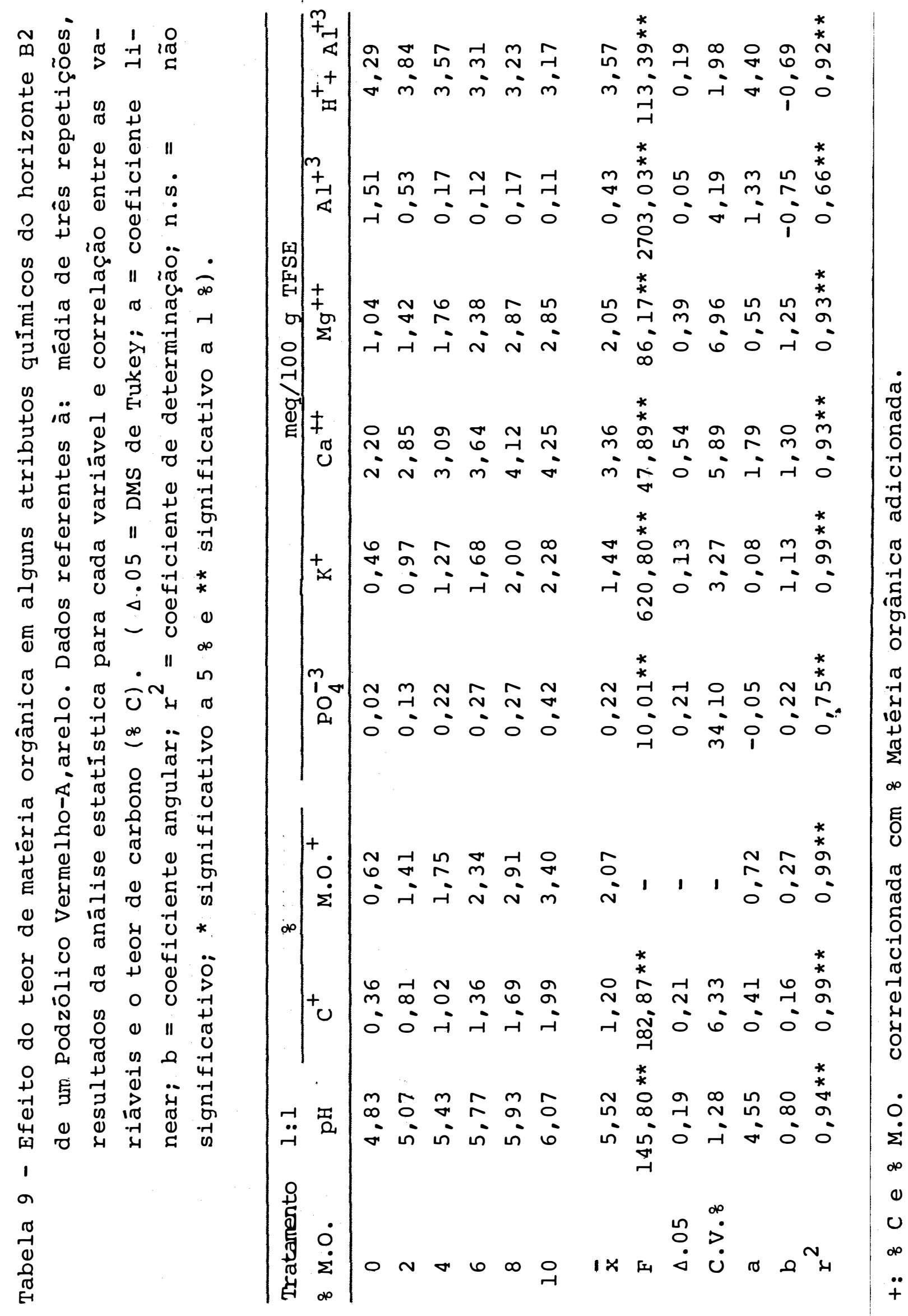




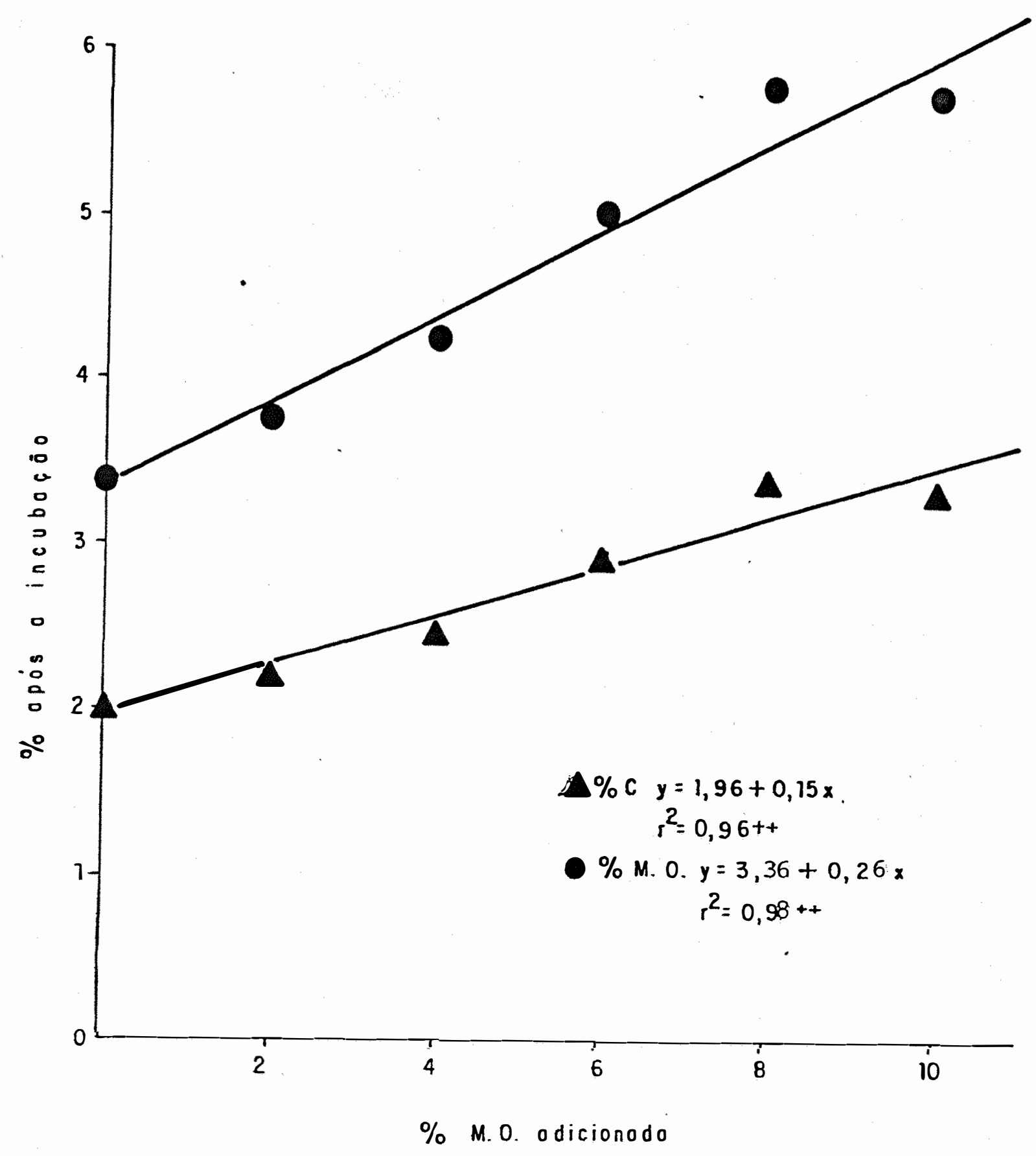

Figura 1 - Teor de carbono (\%) e de matéria orgânica (\%) no horizonte Ap do Latossolo Roxo, após o período de : incubação, em relação à matéria orgânica adicionada. 


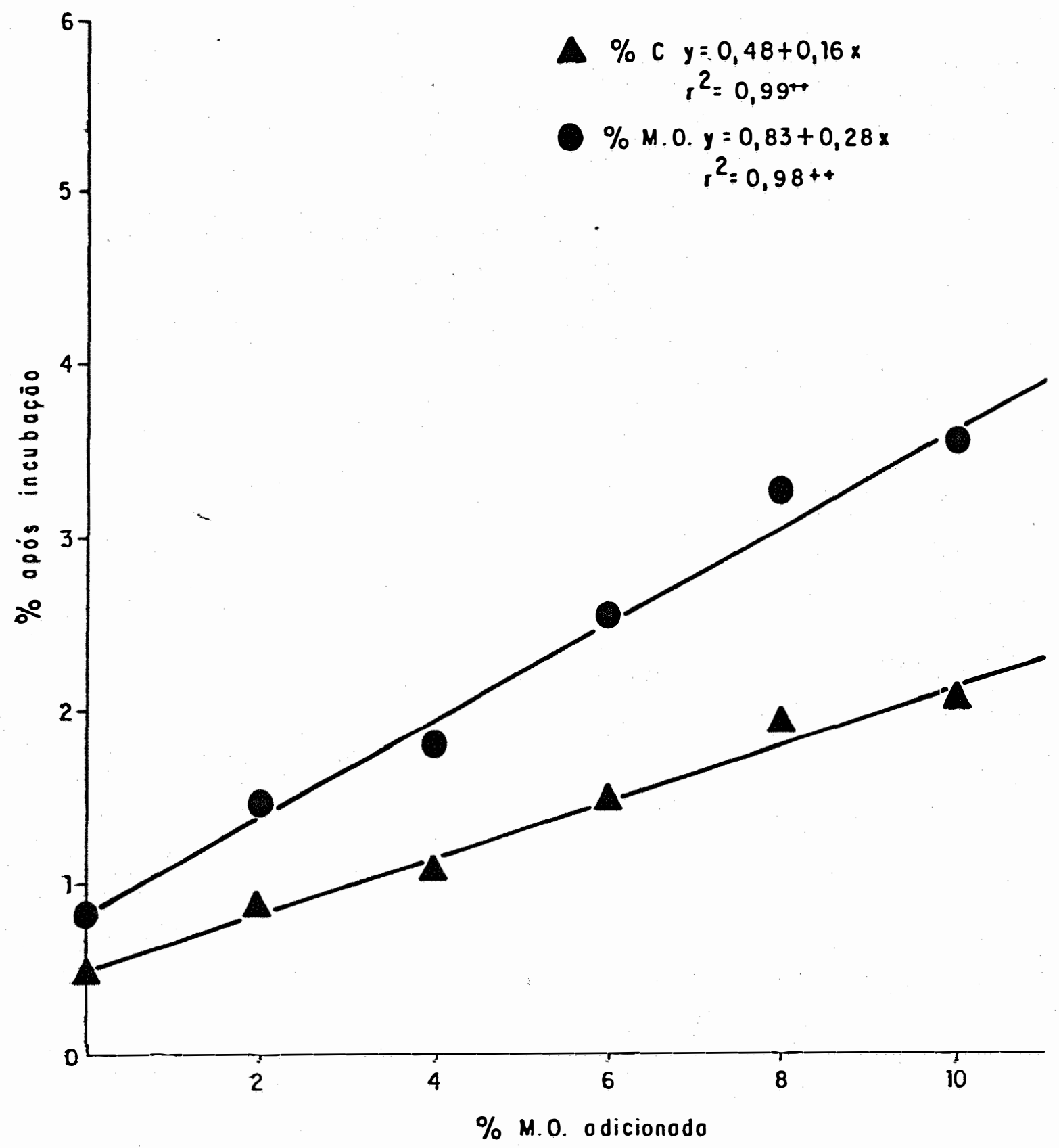

Figura 2 - Teor de carbono $(8)$ e de matéria orgânica $(z)$ no horizonte B2 do Latossolo Roxo, após o período de incubação, em relação à matéria orgânica adicionada. 


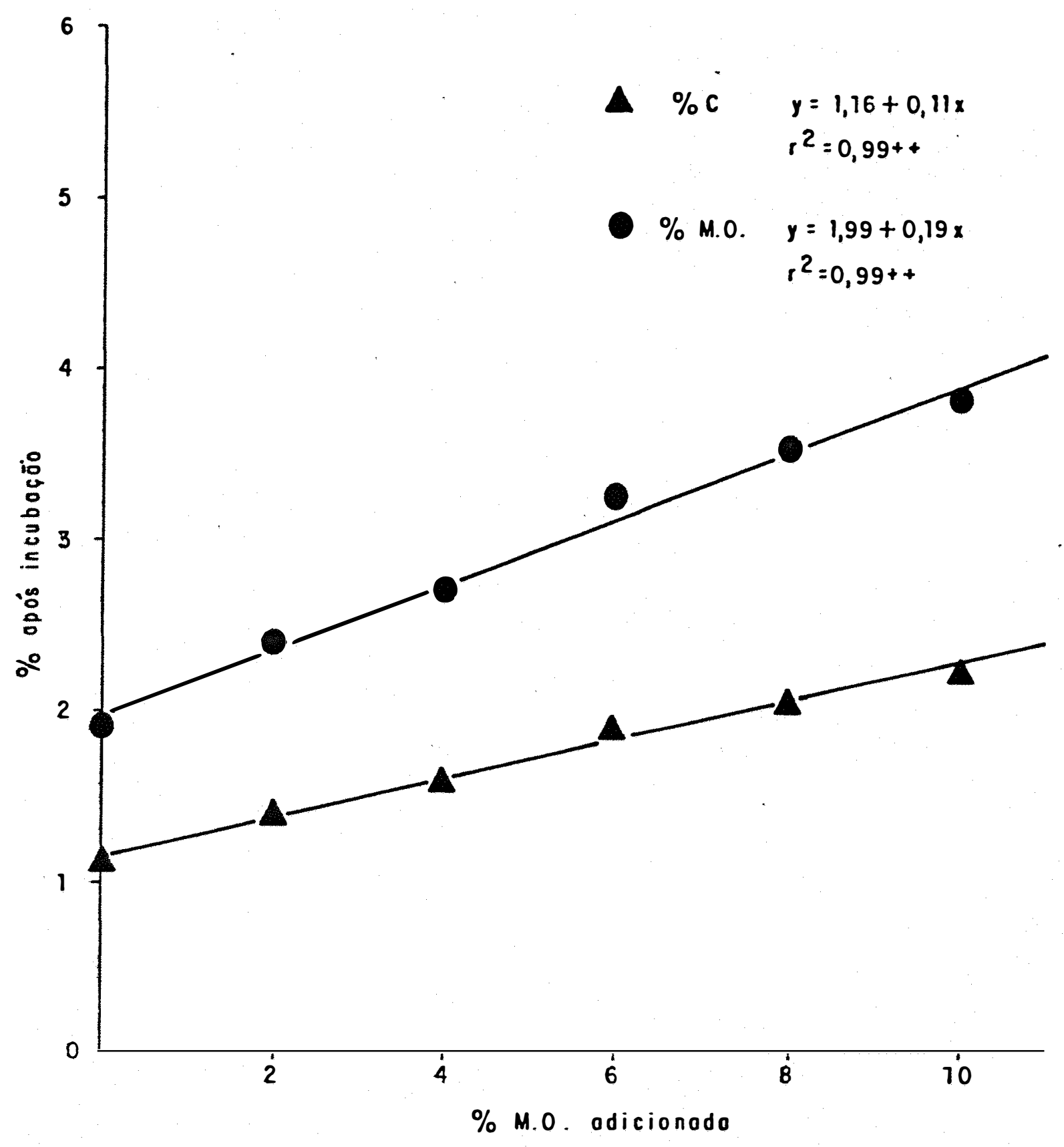

Figura 3 - Teor de carbono (8) e de matéria orgânica (8) no horizonte Al do Podzólico Vermelho-Amarelo, após o período de incubação, em relação à matéria orgânica adicionada. 


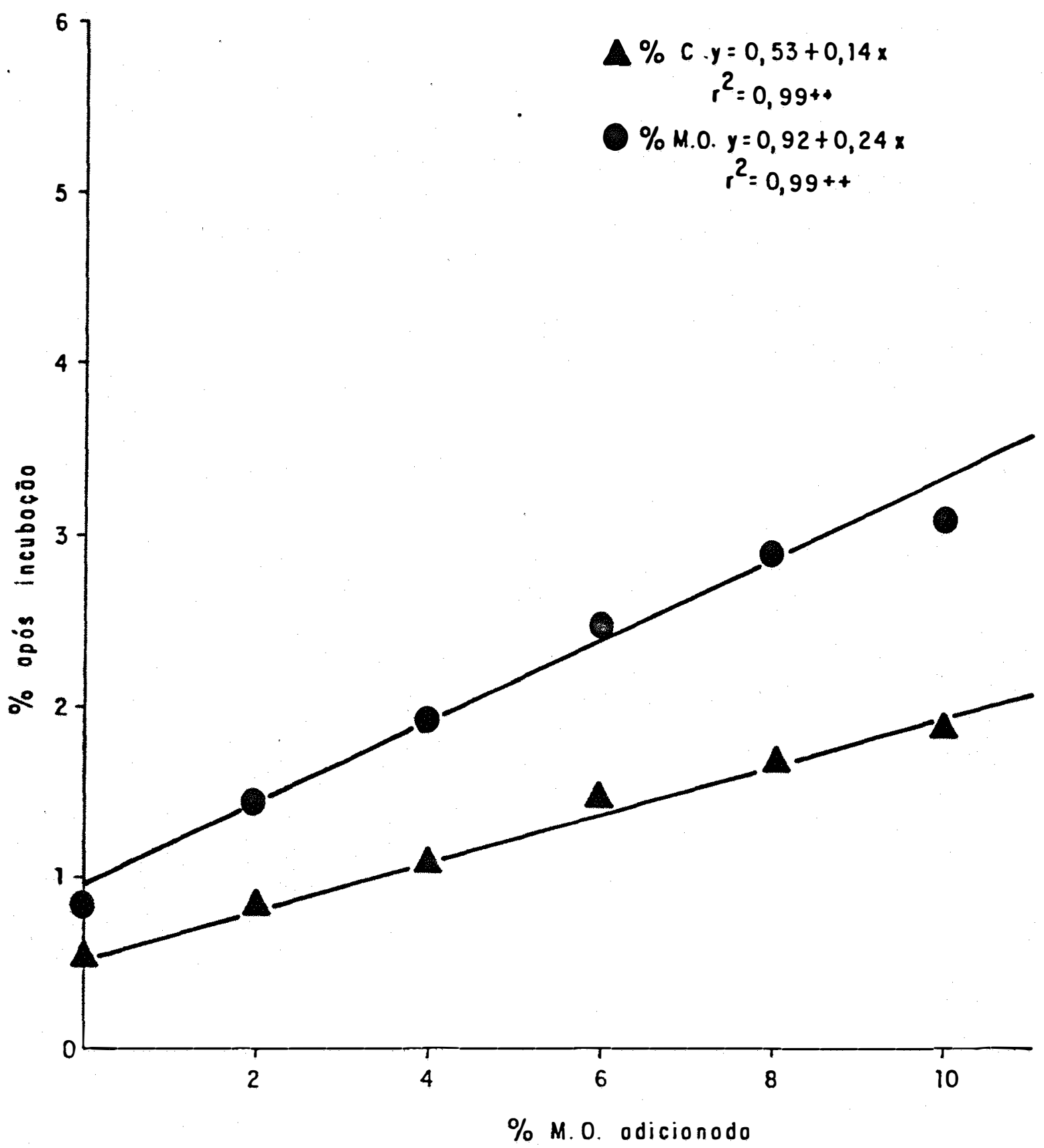

Figura 4 - Teor de carbono (\%) e de matéria orgânica (\%) no horizonte A2 do Podzólico Vermelho-Amarelo, após o perỉodo de incubação, em relação à matéria orgâníca adicionada. 
54 .

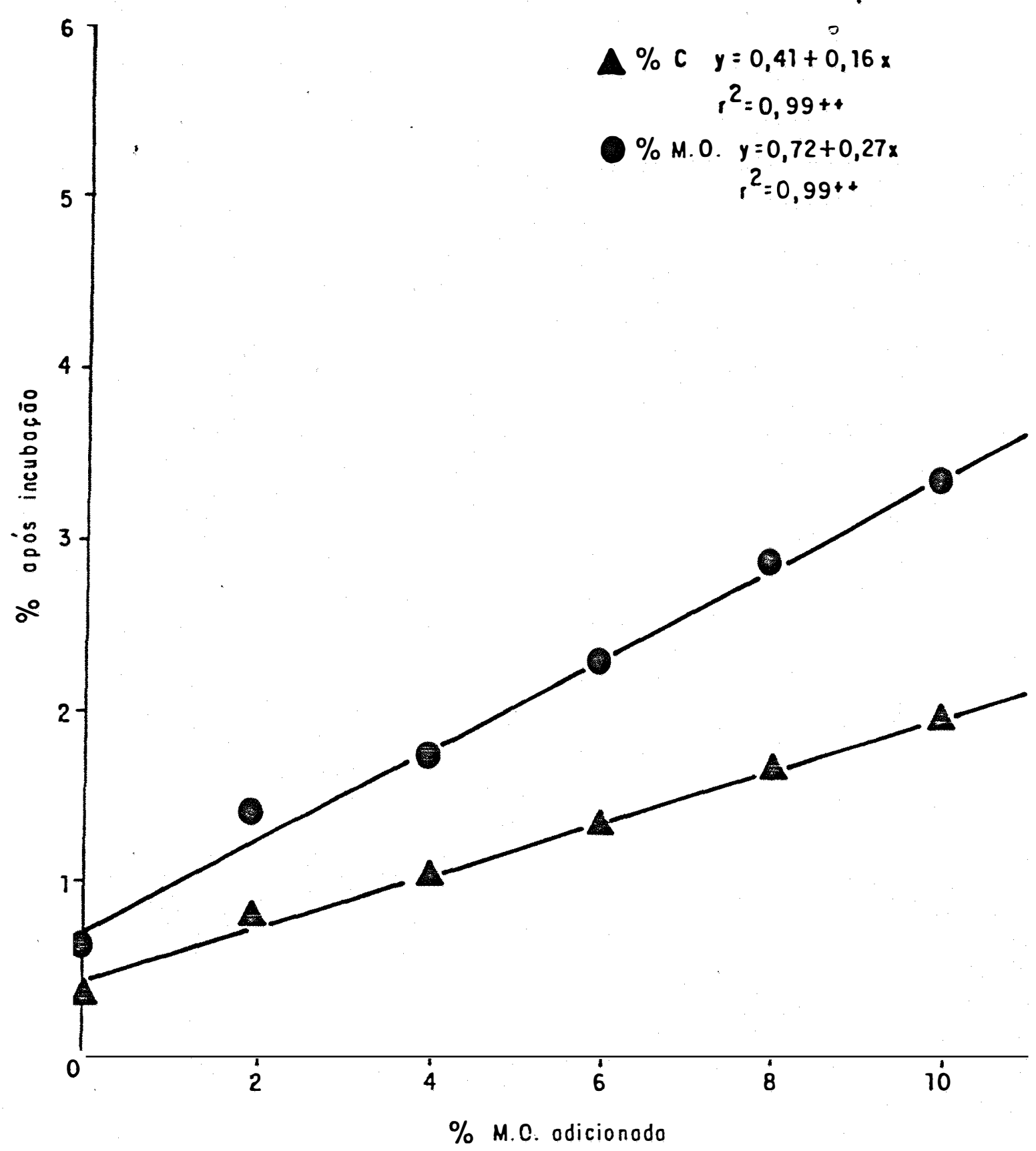

Figura 5 - Teor de carbono (\%) e de matéria orgânica (\%) no horizonte B2 do Podzólico Vermelho-Amarelo, após o período de incubação em relação à matéria orgânica adicionada. 
coeficiente de determinação próximo de 1, em todos os casos, mostra, quantitativamente, que a matéria orgânica aplicada explica, quase que totalmente, os acréscimos de matéria orgânica nos tratamentos após o período de incubação.

Entretanto, enquanto os tratamentos variaram numa progressão aritmética crescente, os acréscimos em car bono orgânico ( \& C $)$, observados em decorrência dos tratamentos, não foram constantes. Para melhor observar esse relacionamento, preparou-se a Tabela 10 que mostra os incrementos gradativos em cada horizonte. E, com o propósito de acrescentar uma idéia de magnitude aos acréscimos aplicados, calcu lou-se, para cada um dos horizontes, a correspondência dos acréscimos a uma aplicação de matéria orgânica em um hectare, incorporada numa camada superficial de $20 \mathrm{~cm}$ de espessura que apresentasse o mesmo valor de densidade que o tratamento testemunha. (Dados das Tabelas 13 e 14). O padrão dos acréscimos no teor de carbono ( $\%$ C) no Latossolo Roxo é diferente do que se nota para os horizontes do Podzólico Vermelho Amarelo.

Embora este não seja um estudo sobre decomposição da matéria orgânica no solo, pode-se perceber que os dados indicam que o teor de carbono orgânico no solo tende a um equilíbrio, como reafirmaram recentemente LATHWELL e BOULDIN (1981). Eles sugeriram, também, que o tempo necessário 


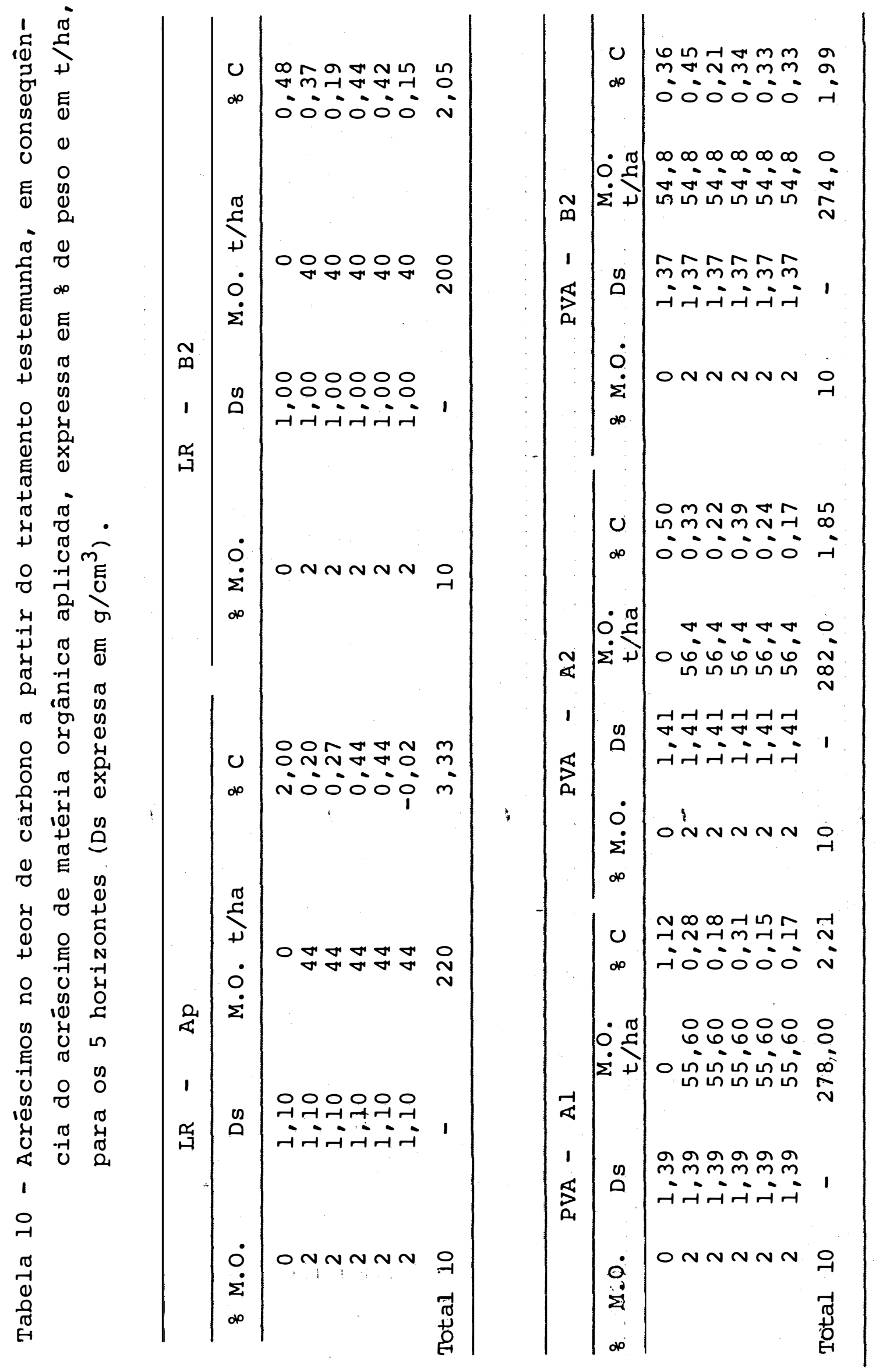


para atingir esse equilíbrio depende da interação entre as quantidades adicionadas e as demais condições existentes.Estas, evidentemente, controlam a atividade biológica,reconhecida como o principal fator para a decomposição do material orgânico do solo. OVCHNNIKOVA et alii (1978) mostraram, em estudos com solos Podzólicos da região temperada da Russia, que a combinação dos fatores que controlam a atividade microbiana é complexa. $\mathrm{O}$ pH da solução parece ser 0 fator mais limitante, mas o teor de água, e a consequente aeração, são fundamentais para a decomposição aeróbica.

De acordo com FOTH e TURK (1972), o aumento adequado de precipitação, além de ser favorável ao bom desenvolvimento de plantas, exerce um efeito marcante no con teúdo de matéria orgânica do solo. Através da lixiviação,ela pode fazer com que $\circ \mathrm{pH}$ das camadas superficiais do solo baixe para 4,5 ou menos. Sob esta condição, a decomposição da matéria orgânica por microrganismos pode tornar-se tão limitante que os resíduos adicionados à superfície do solo acumulam-se muito mais do que se decompõem. Isto contribui, em grande parte, para a formação de horizonte orgânico em alguns solos de floresta.

Neste trabalho as frequentes irrigações e elevada temperatura ambiente $\left(28^{\circ} \mathrm{C}\right)$, contribuiram para um resultado semelhante ao relatado por FOTH e TURK. 
Com a elevação dos teores de matéria orgânica, verificou-se um aumento significativo nos teores de fósforo disponível, cátions trocáveis, carbono e pH, enquanto que o comportamento do aluminio e do hidrogênio foi variável, comparativamente, para os 5 horizontes.

No horizonte Ap do Latossolo Roxo, os teores de cátions trocáveis, carbono e matéria orgânica foram maiores do que no B2, devido ao seu maior valor original; observa-se que o teor de fósforo, entretanto, atinge valores mais elevados, relativamente, no horizonte Ap.

Examinando-se os três horizontes do Podzólico Vermelho-Amarelo, constatou-se um efeito significativo e positivo dos tratamentos para todos os atributos químicos estudados. Entretanto, o alumínio e hidrogênio apresentam uma relação inversa, decrescendo com o acréscimo da matéria orgânica.

A incorporação dos resíduos orgânicos ao solo provocou diminuição nos teores de aluminio trocável (Tabelas de 5 a 9 inclusive), fato também verificado por HOYT e TUR NER. (1975) e HOYT (1977). Esses autores consideraram que tal efeito é devido à complexação do alumínio por moléculas orgânicas e à precipitação deste elemento nas regiões imedia - 
tamente adjacentes às partículas orgânicas, como consequên cia da elevação do $\mathrm{pH}$ do solo nessas regiões (ERNANI e GIANELLO, 19811 .

A CTC sofreu um aumento com a elevação do teor de matéria orgânica em todos os horizontes e seus respectivos tratamentos, conferindo ao solo maior adsorção de cátions trocáveis liberados pela decomposição da matéria orgânica. Como consequência da elevação da CTC e dos cátions trocáveis, verificou-se um aumento da saturação de bases o que causou, nos horizontes do Podzólico Vermelho-Amarelo, a elevação do pH e diminuição do alumínio trocável.

O diferente comportamento entre os horizontes do Latossolo Roxo comparados aos do Podzólico Vermelho-Ama relo, particularmente quanto ao $\mathrm{Al}, \mathrm{H}$ e $\mathrm{pH}$, talvez seja devido ao teor mais elevado de óxidos de ferro no Latossolo Roxo. Esta relação já foi anteriormente sugerida por OVCHN NIKOVA et alii (1978).

Não se pretende discutir, nesta oportunidade, a natureza desse relacionamento. A literatura a respeito ainda é controvertida. Talvez haja uma relação entre os constituintes do solo e as propriedades das frações orgânicas que são decompostas conforme a sua resistência. Dos trabalhos 
efetuados por VERDADE (1956), verificou-se que, nos solos argilosos. as primeiras frações destruidas da matéria orgânica possuem pequena capacidade de troca de cátions, enquanto as mais resistentes têm essa propriedade em maior escala. Nos solos arenosos, todas as frações orgânicas parecem apresen tar a capacidade de troca com a mesma magnitude. Segundo esse mesmo autor, nos solos arenosos e terra roxa, há indica ções de existir um teor crítico de carbono, abaixo do qual a fração orgânica inibe a capacidade de troca de cátions da fração mineral. Acima desse teor deve também haver diminui ção, porém, em virtude da matéria orgânica possuir alta capacidade de troca, tal fenômeno não è aparente.

Os resultados apresentados permitem afirmar que do processo de decomposição da matéria orgânica, acres centada aos horizontes do Latossolo Roxo e do Podzólico Vermelho-Amarelo, resulta um aumento no teor de carbono orgânico numa relação linear. Com o prolongamento do período de decomposição esse teor tende a decrescer. Quanto à liberação dos nutrientes $\mathrm{K}, \mathrm{P}, \mathrm{Ca}$ e $\mathrm{Mg}$, esta é proporcional ao teor desses elementos no material aplicado, como se depreende da comparação entre os dados da Tabela 2 e os das Tabelas 5 a 9 , inclusive. A título de ilustração observe-se na Figura 6 a a estreita relação entre os teores de $\mathrm{K}$ e $\mathrm{C}$ obtidos nos tratamentos aplicados no horizonte B2 do Podzólico Vermelho-Ama - 


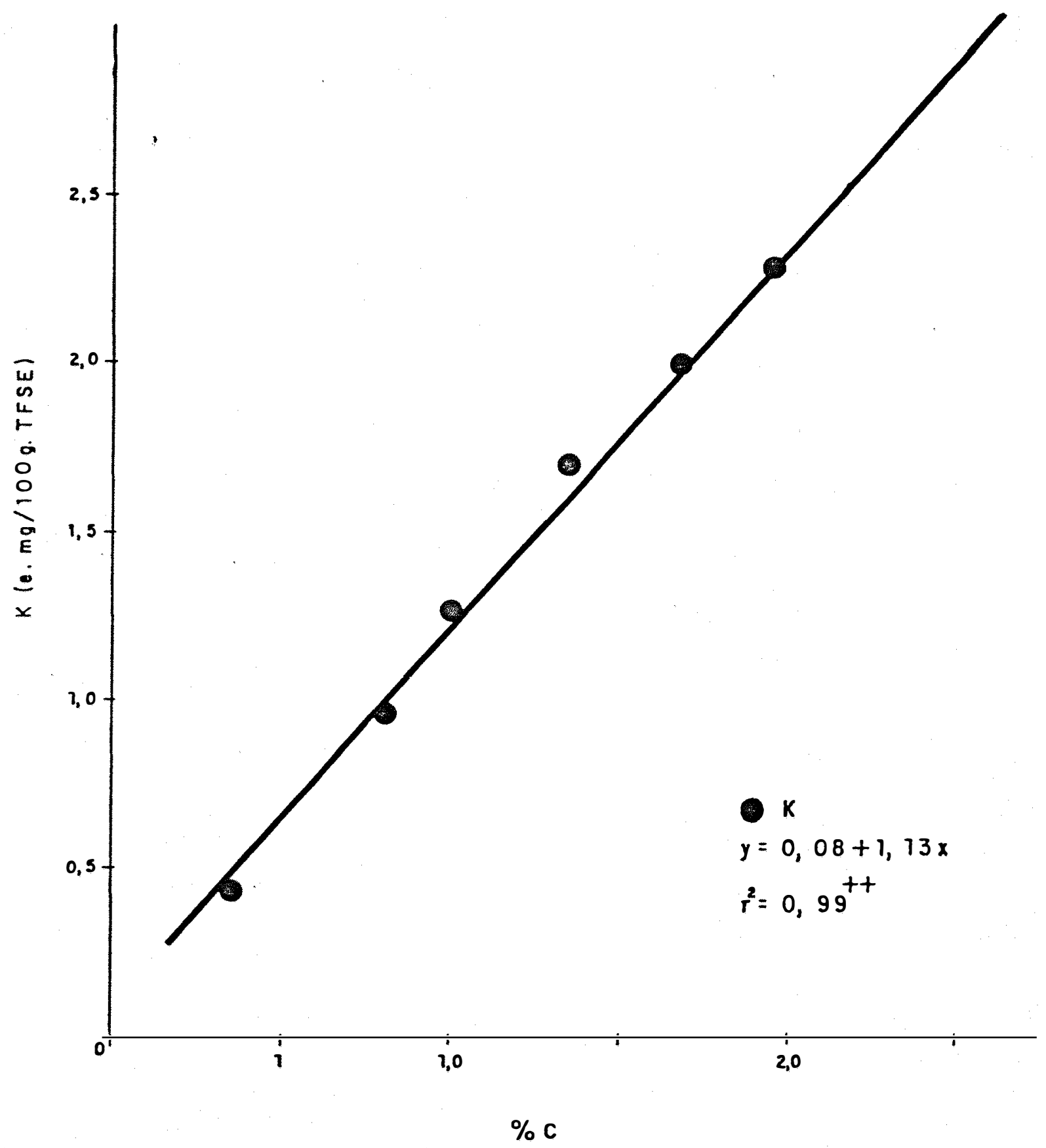

Figura 6a - Teor de potássio (K) em relação ao \& C após o período de incubação da matéria orgânica adicionada ao horizonte B2 do PVA. 
relo. As variações observadas entre os horizontes são atribuidas à diversidade na atividade biológica em relação às quantidades adicionadas e às características de cada horizonte.

4.2. Experimento 2: Efeito da matéria orgânica na granulometria

Conforme já comentado na revisão de literatura, a participação da matéria orgânica na granulometria do solo está relacionada especialmente com o seu efeito em análises feitas para determinar a distribuição de partículas por tamanho.

Neste estudo, obteve-se resultados analíticos que evidenciam que a influência da matéria orgânica não é a mesma em todas as frações granulométricas. Os dados médios relacionados aos tratamentos, para cada um dos cinco horizontes estudados, são apresentádos nas Tabelas 11 e 12, São apresentados, também, os parâmetros estatísticos relativos à análise da variância, comparação entre médias e regressão linear.

Analisando as tabelas, constata-se que a decomposição de níveis crescentes de matéria orgânica, adicio- 
63.

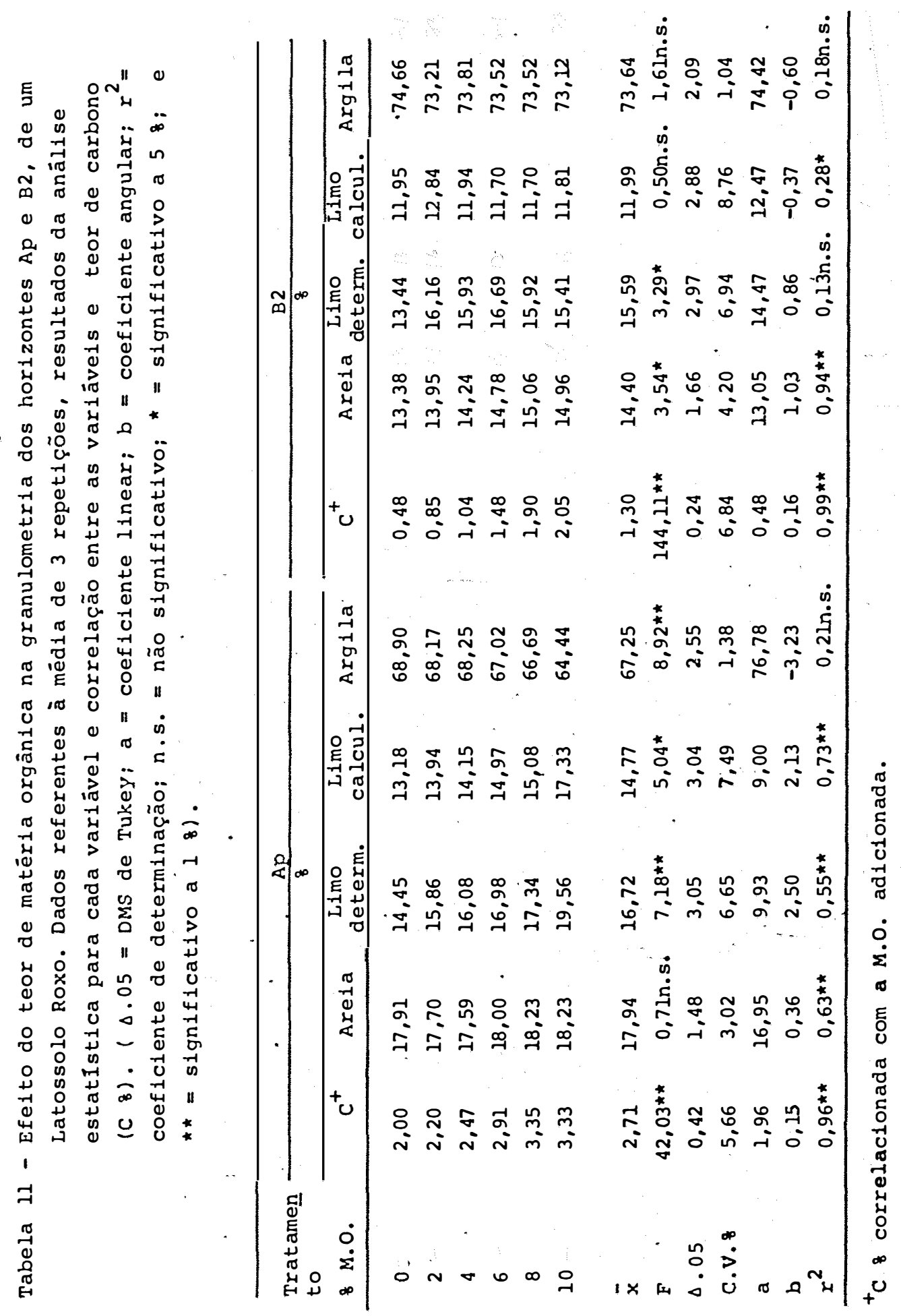




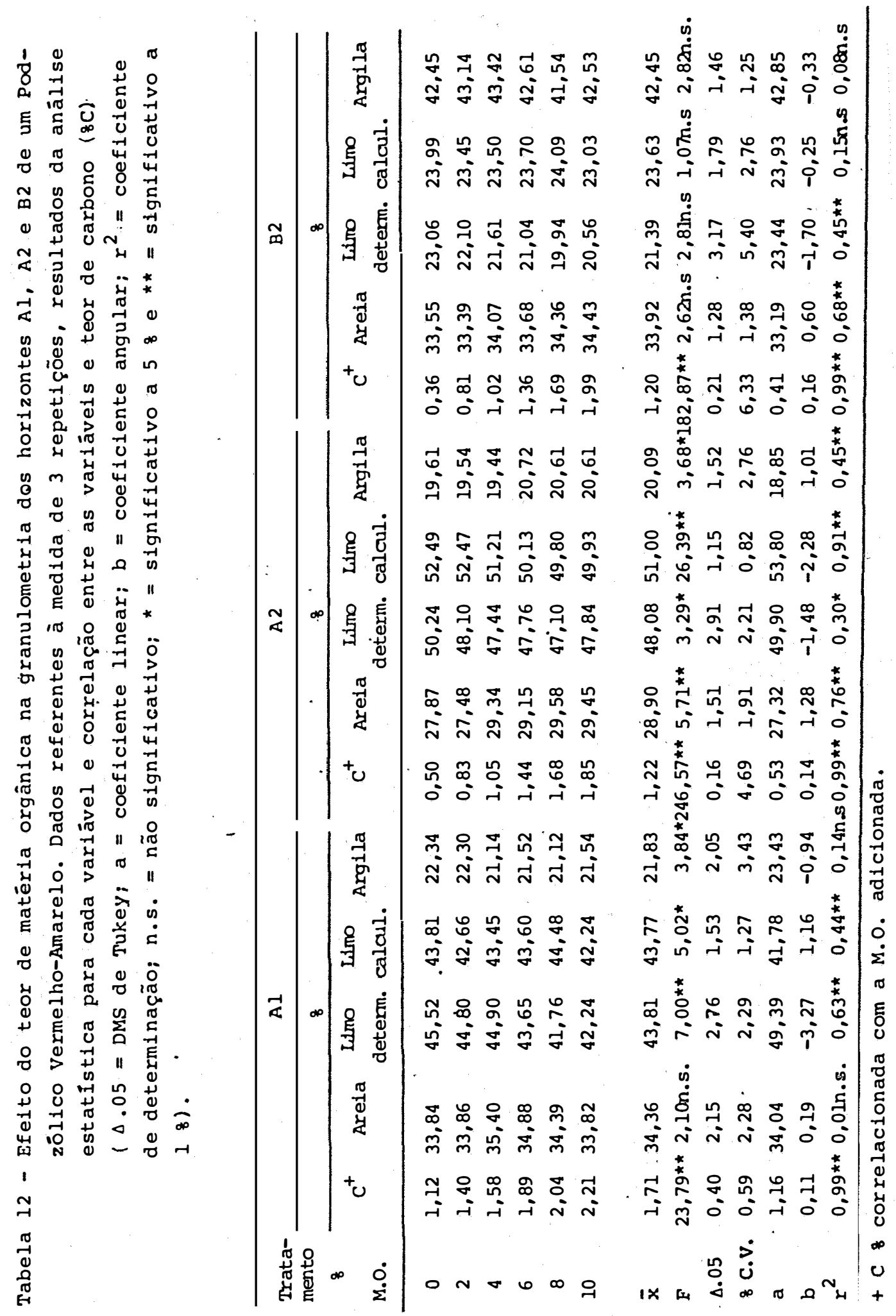


nados às amostras dos horizontes, provocou modificações sigficativas nos resultados da análise granulométrica, exceto para o horizonte B2 do PVA que não mostrou efeito significativo para nenhuma das frações (areia, limo e argila).

Segundo as interpretações estatísticas, a fração limo é a que aparece com alteração mais constante. Notase, entretanto, que enquanto o efeito da matéria orgânica sobre o teor de limo é positivo para os horizontes do LR, é negativo para os horizontes Al e A2 do PVA.

No caso dos horizontes Ap e B2 do LR, pode-se explicar esse efeito pela diminuição, aproximadamente proporcional, do teor de argila determinada com o aumento do teor de matéria orgânica aplicada. Pode-se supor que se trata de um efeito semelhante ao descrito por BROERSMA e LAVKULICH (1980), isto é, simples presença de material orgânico na fraÇão limo. Mas, para os horizontes Al e A2 do PVA, nos quais - limo mostrou uma relação negativa com o acréscimo de matéria orgânica, parece que o ligeiro aumento registrado no teor de areia poderá explicar essa ocorrência. Neste caso, a sugestão é que partículas de limo ligadas por material orgânico passaram para a fração areia.

Esses resultados refletem as variadas condições oferecidas pelos horizontes para a decomposição da ma- 
téria orgânica e consequente efeito na análise granulométri-.: ca. Embora os resultados do teor de carbono ( 8 C), em todos os horizontes, indiquem que a matéria orgânica ! :adicionada contribuiu para aumentar o teor de coloides, esse aumento, ainda que percentualmente elevado é, em termos absolutos,desprezível. Por esta razão, o teor de argila determinada não foi afetado pelos tratamentos no caso do horizonte B2 do LR, que apresenta elevado teor de argila (cerca de 75 \%).

Pode-se dizer que, embora os resultados não sejam perfeitamente consistentes em todos os casos, há evi dências de que a presença de matéria orgânica afeta a análise granulométrica; principalmente quanto aos resultados obtidos para o limo. Parece que este efeito é mais acentuado quando ocorre a combinação de teor mais baixo de limo e t.eores mais elevados de matéria orgânica e argila.

E fossível que nesses horizontes tenha ocor rido o mesmo que foi observado por ALEXANDROVA et alii (1964), isto é, que as substâncias húmicas estão presentes em todas as frações e aparecem tanto como partículas discretas quanto como películas revestindo os grânulos das frações minerais . Dessa maneira o seu efeito talvez seja melhor percebido examinando-se as variações relativas dos resultados da análise granulométrica e dos teores de carbono após a incubação. Para ilustrar essa posição, preparou-se as Figuras 6 a 10 , in- 
67.

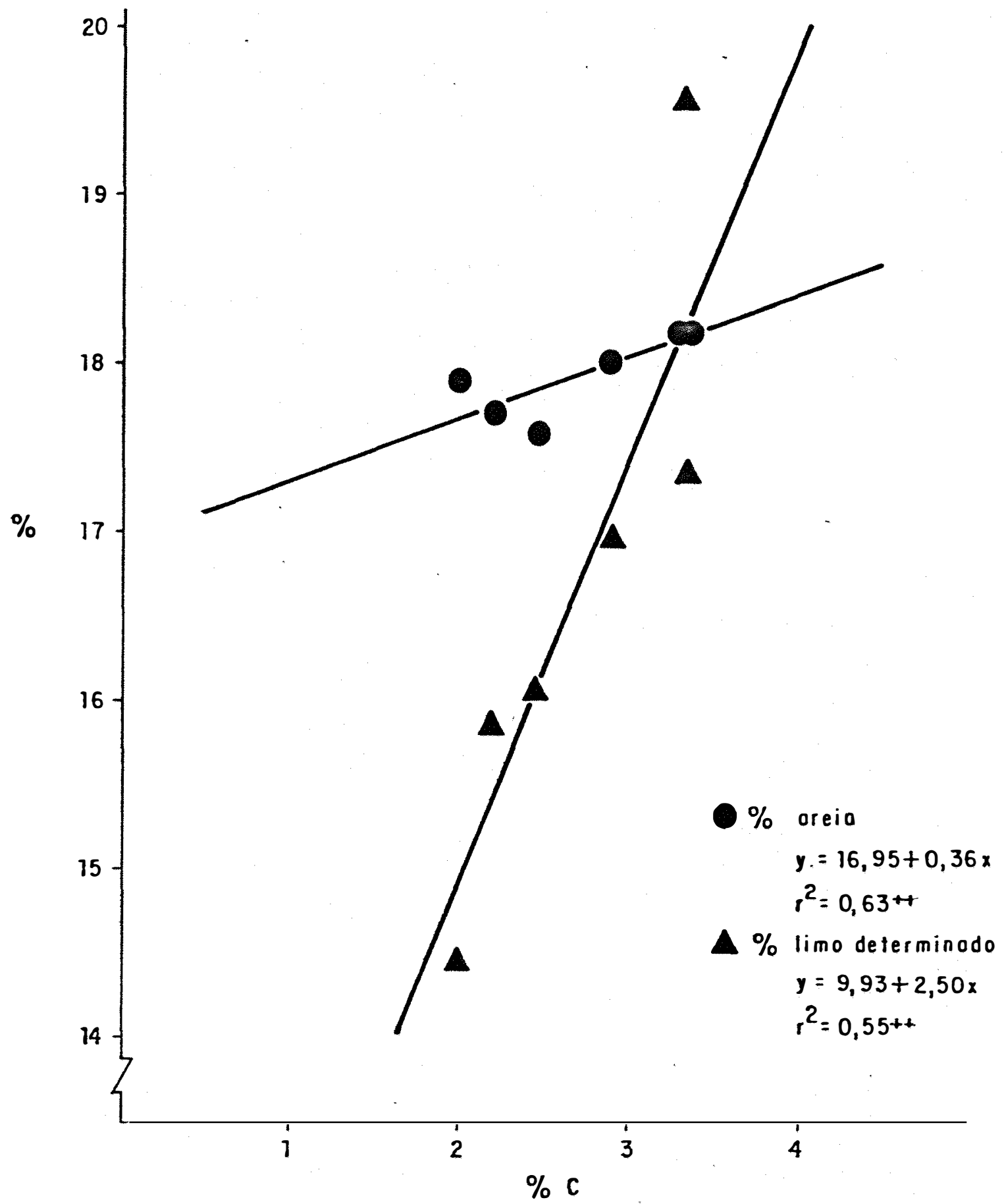

Figura 6 - Teores de areia e de limo determinado no horizonte Ap do Latossolo Roxo após o período de incubação , em relação ao teor de carbono dos tratamentos após o período de incubação. 
68.

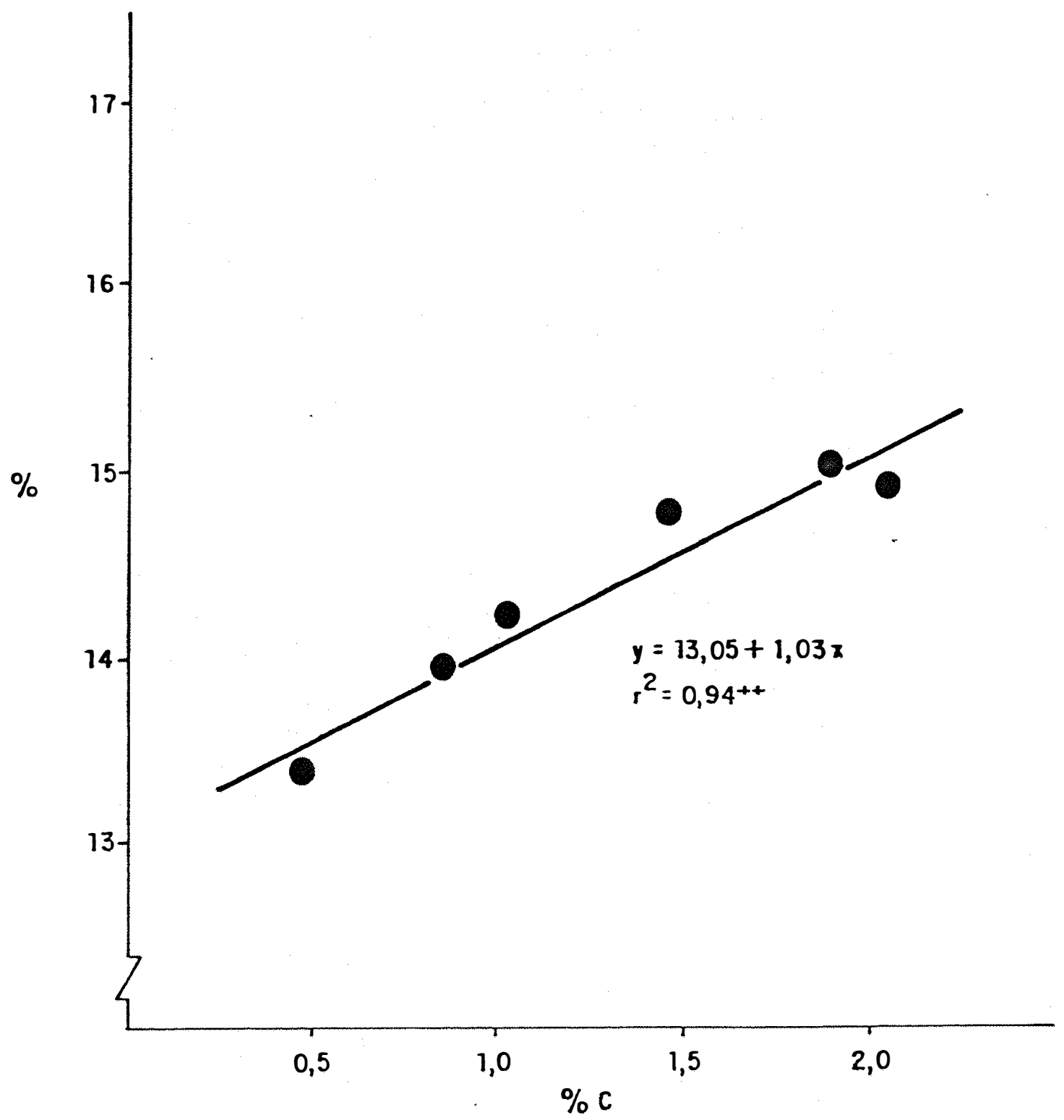

Figura 7 - Teor de areia no horizonte B2 do Latossolo Roxo, após o período de incubação, em relação ao teor de carbono dos tratamentos após o período de incubação. 
69.

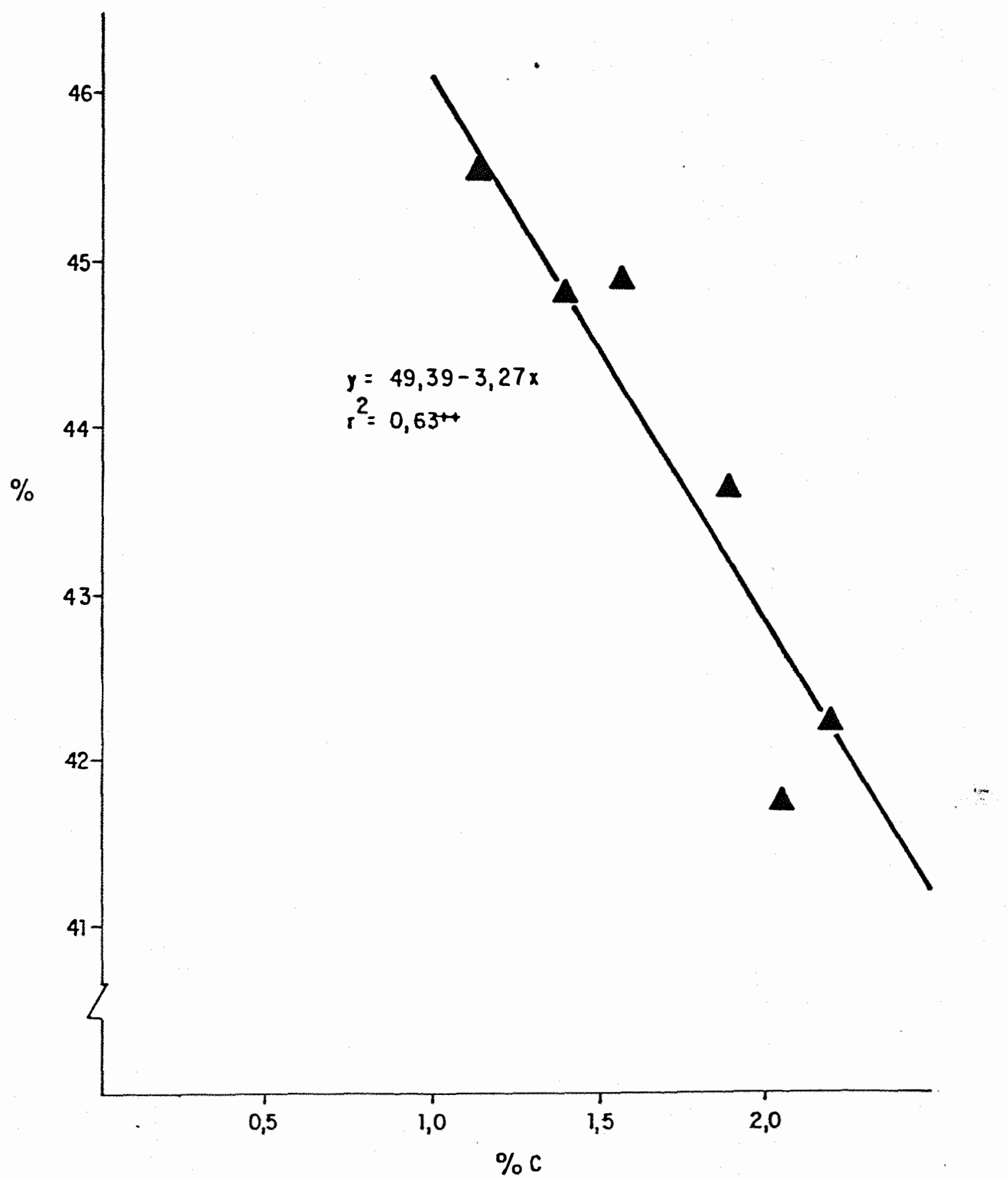

Figura 8 - Teor de limo determinado no horizonte Al do Podzólico Vermelho-Amarelo, após o período de incubação, em relação ao teor de carbono dos tratamentos após o periodo de incubação. 


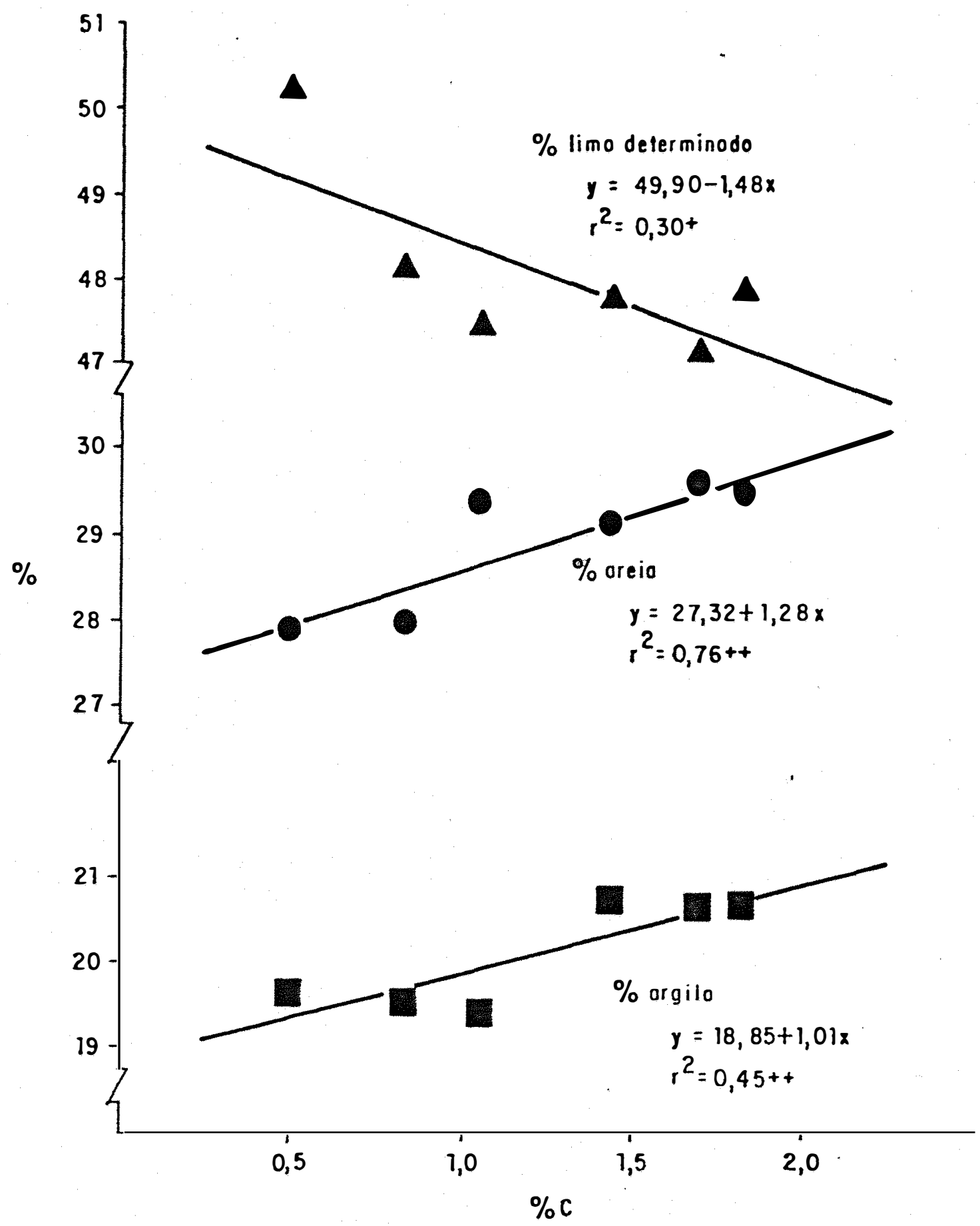

Figura 9 - Teor de areia, limo determinado e argila no horizonte A2 do Podzólico vermelho-Amarelo, após o período de incubação, em relação ao teor de carbono dos tratamentos após o período de incubação. 
71.

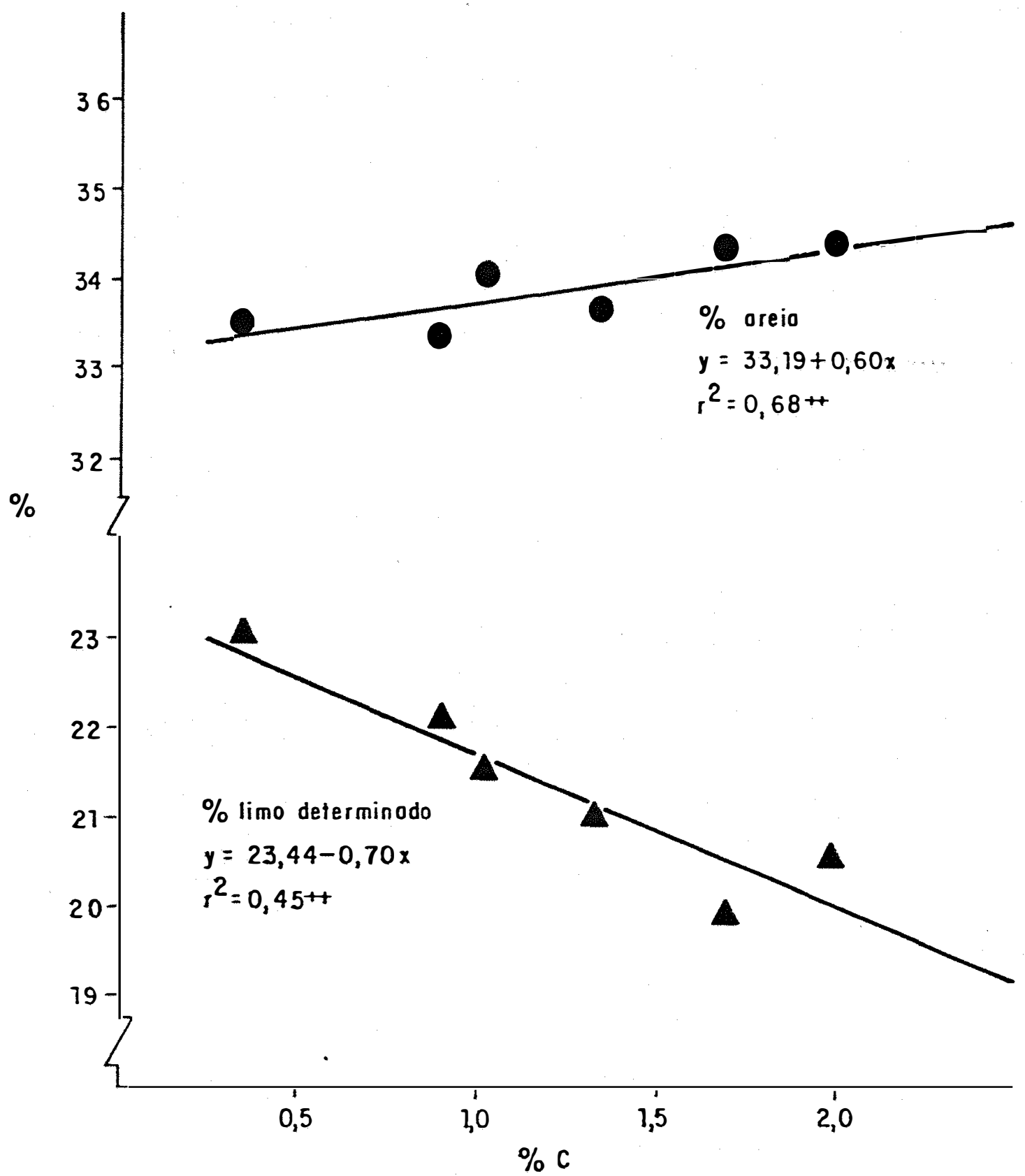

Figura 10 - Teor de areia e limo determinado no horizonte B2 do Podzólico Vermelho-Amarelo, após o período de incubação, em relação ao teor de carbono dos tratamentos após o período de incubação. 
clusive, que mostram a regressão linear de algumas das frações em função do teor de carbono dos respectivos tratamentos. São apresentados apenas os casos em que se observou um coeficiente de determinação $\left(r^{2}\right)$ significativo.

A Figura 6, por exemplo, mostra claramente 0 efeito mais acentuado do acréscimo de matéria orgânica sobre - teor de limo em comparação com o efeito sobre o teor de areia. Embora o coeficiente de determinação seja semelhante, nos dois casos, o coeficiente angular é mais elevado no caso da relação \& C e limo. O mesmo se verifica para os horizontes A1 e A2 do PVA.

Do exposto e do que se pode notar da análise dos resultados, conclui-se que há um efeito variável do teor da matéria orgânica nos resultados da análise granulométrica. Esse efeito parece ser de natureza predominantemente indireta, isto é, uma consequência da decomposição da matéria orgânica. Embora o teor de matéria orgânica seja reduzido após a decomposição, este teor divide-se entre a fração coloidal e a fração silte. 
4.3. Experimento 3: Efeito do teor de matéria orgânica na densidade do solo (Ds) e na densidade das partículas $\underline{(D p)}$

A decomposição de teores crescentes de matéria orgânica adicionadas às amostras dos horizontes Ap e B2 do Latossolo Roxo, série Iracema e Al, A2 e B2 do Podzólico Vermelho-Amarelo, série Quebra Dente, provocou nítidas modificaÇões na densidade do solo, na densidade das partículas, na porosidade total (o: E) e na porosidade livre de água (Pla), como se pode obaservar nas Tabelas 13 e 14. Estes foram os efeitos mais marcantes e consistentes dentre os que foram considerados neste trabalho. O exame detalhado das tabelas apresenta das revela o efeito direto e indireto da matéria orgânica sobre a densidade do solo.

Verificou-se uma diminuição na densidade do solo, na densidade das partículas e um aumento na porosidade total e na porosidade livre de água com a elevação do teor de matéria orgânica.

A análise de variância, apresentada nas Tabe las 13 e 14, mostra os efeitos altamente significativos em todos os tratamentos e para os 5 horizontes estudados. 


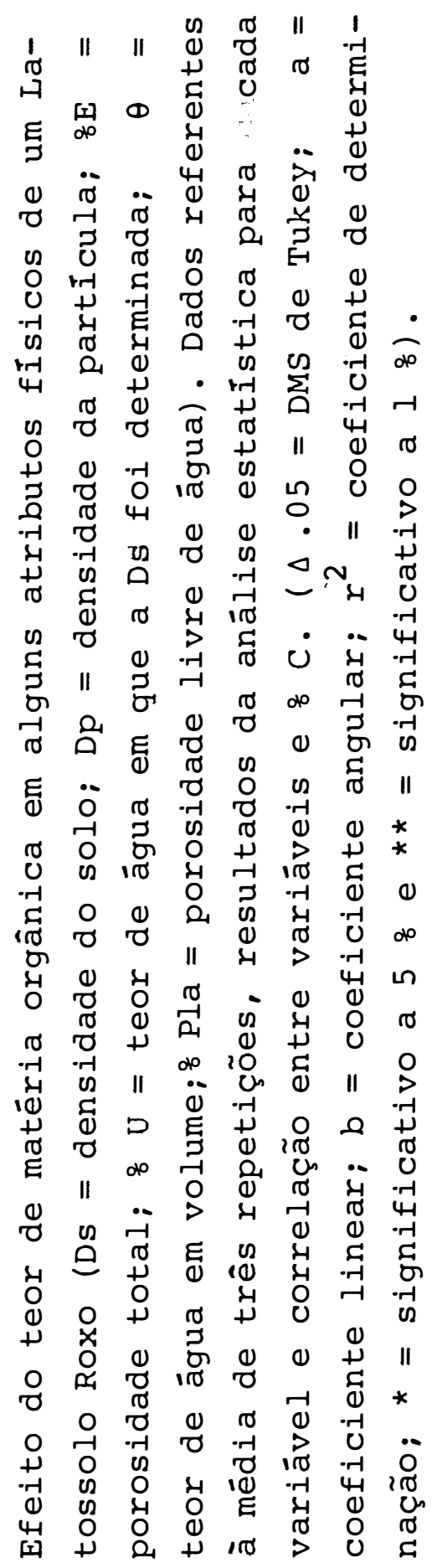

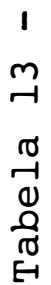

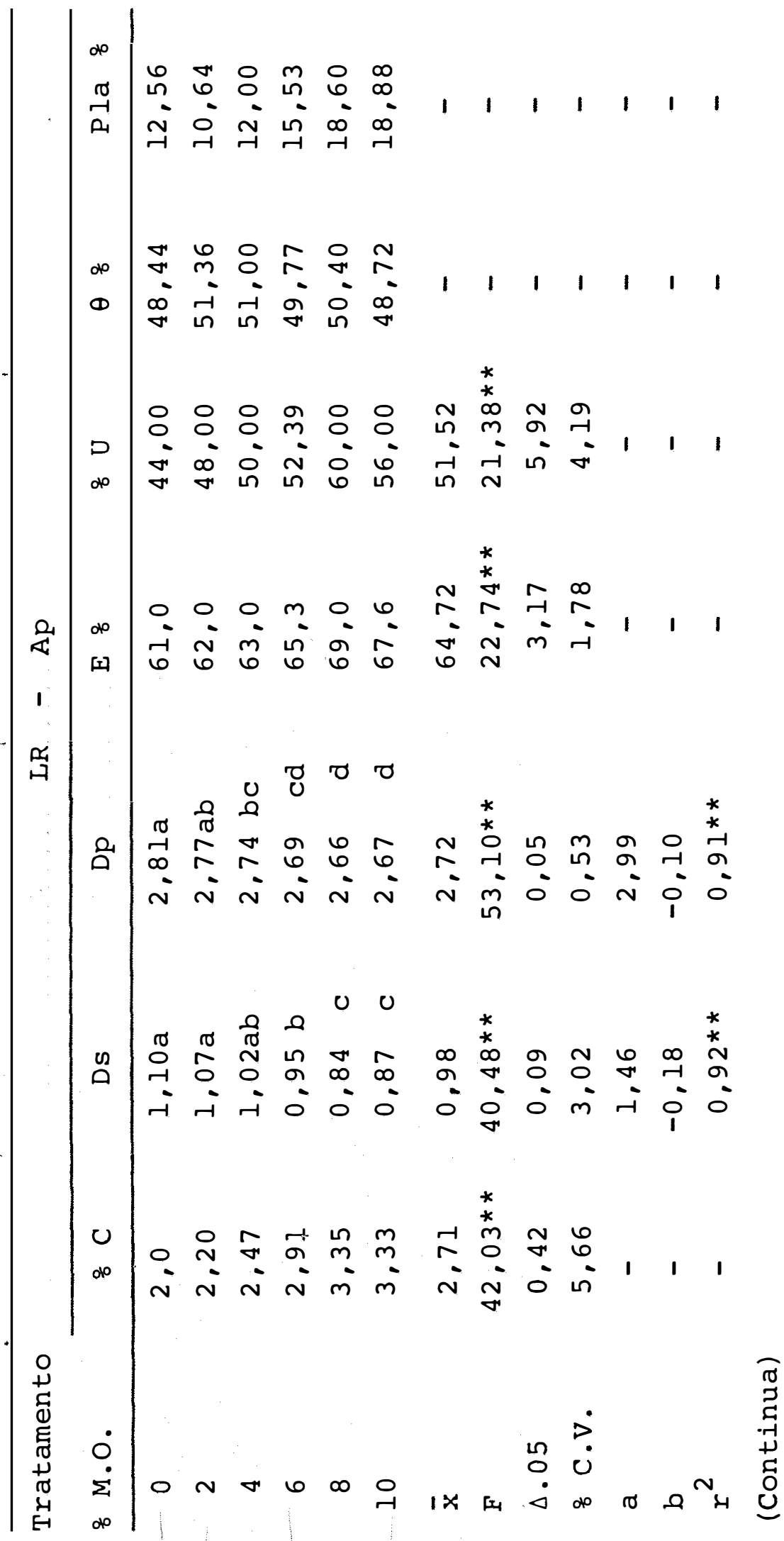


75.

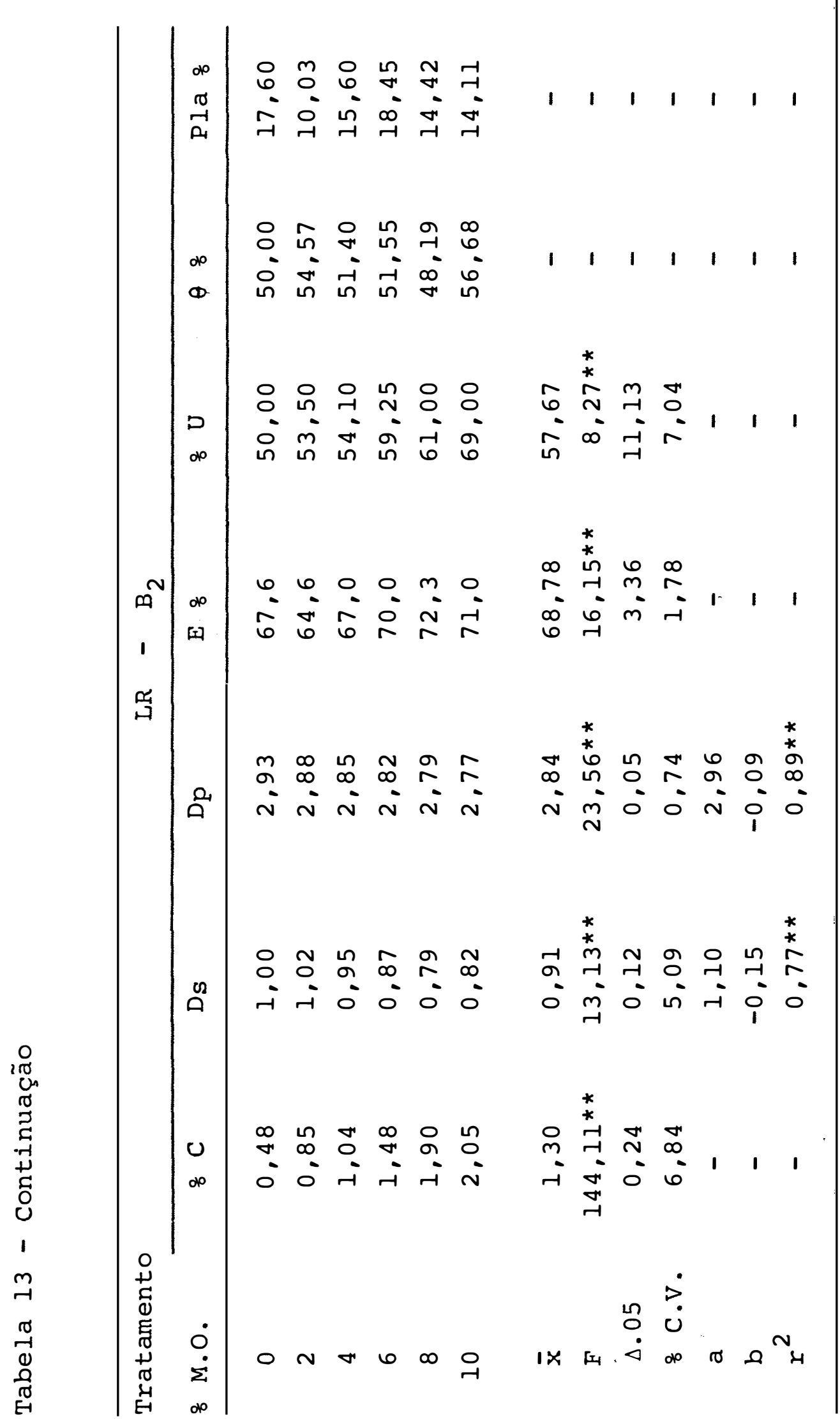



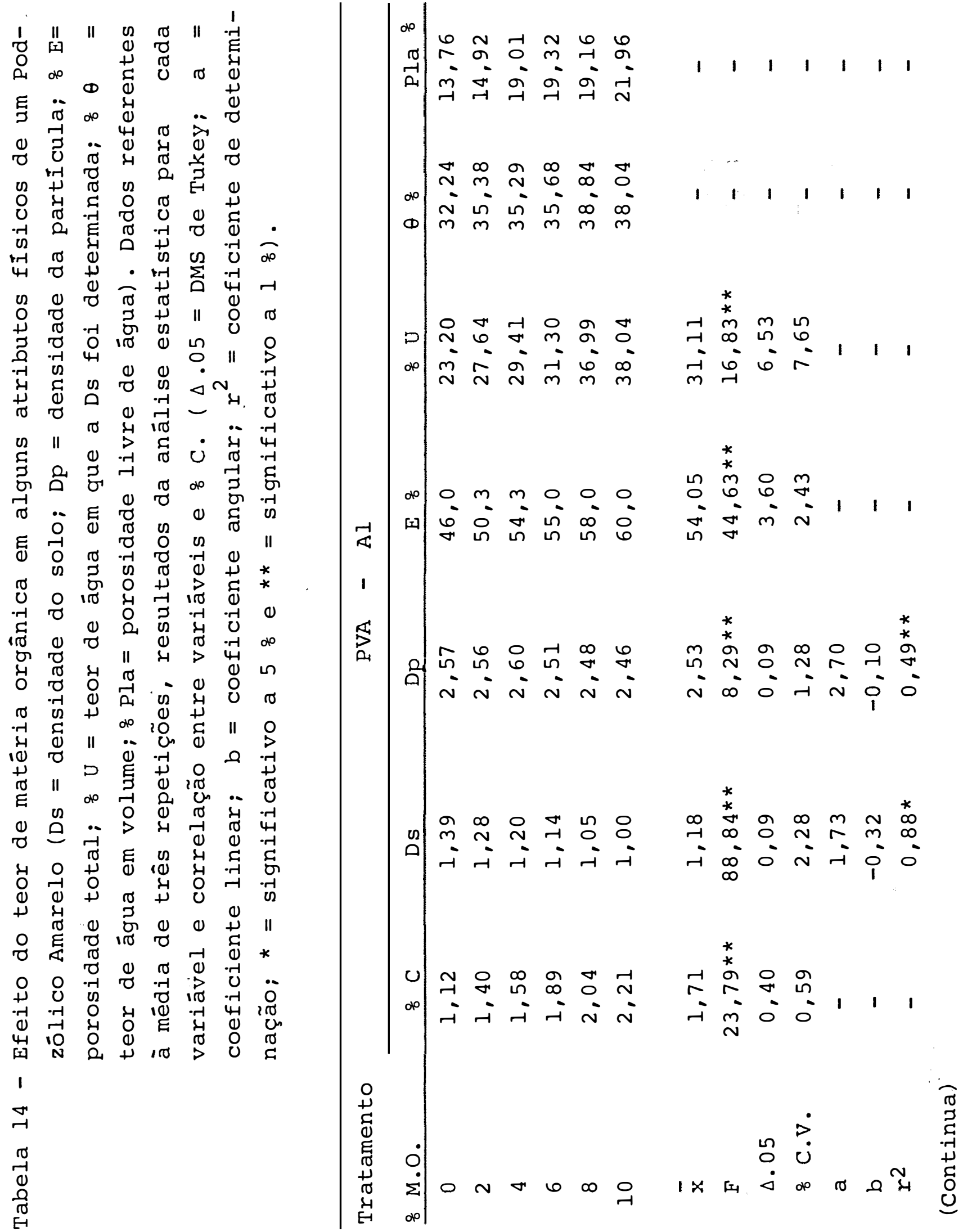


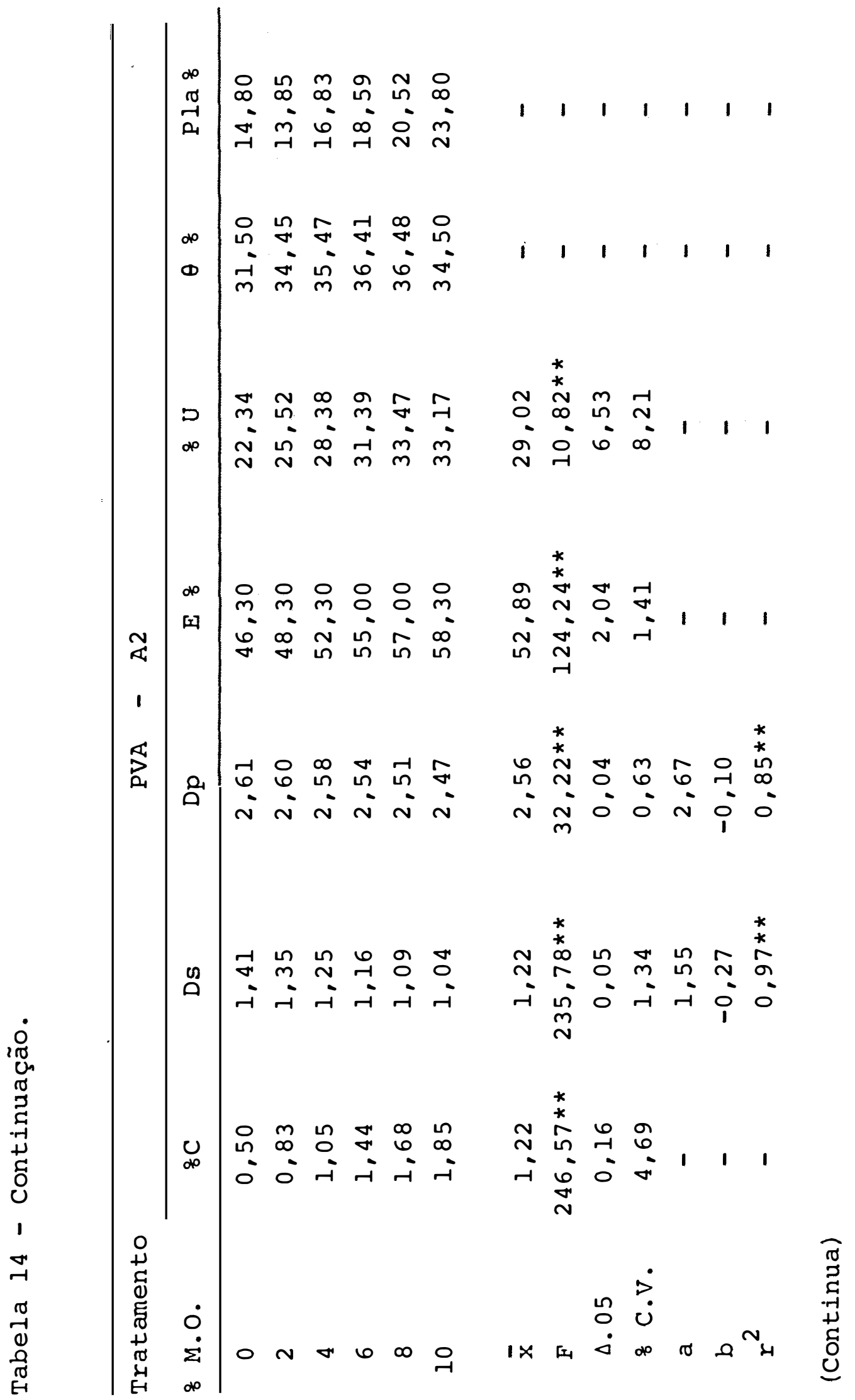




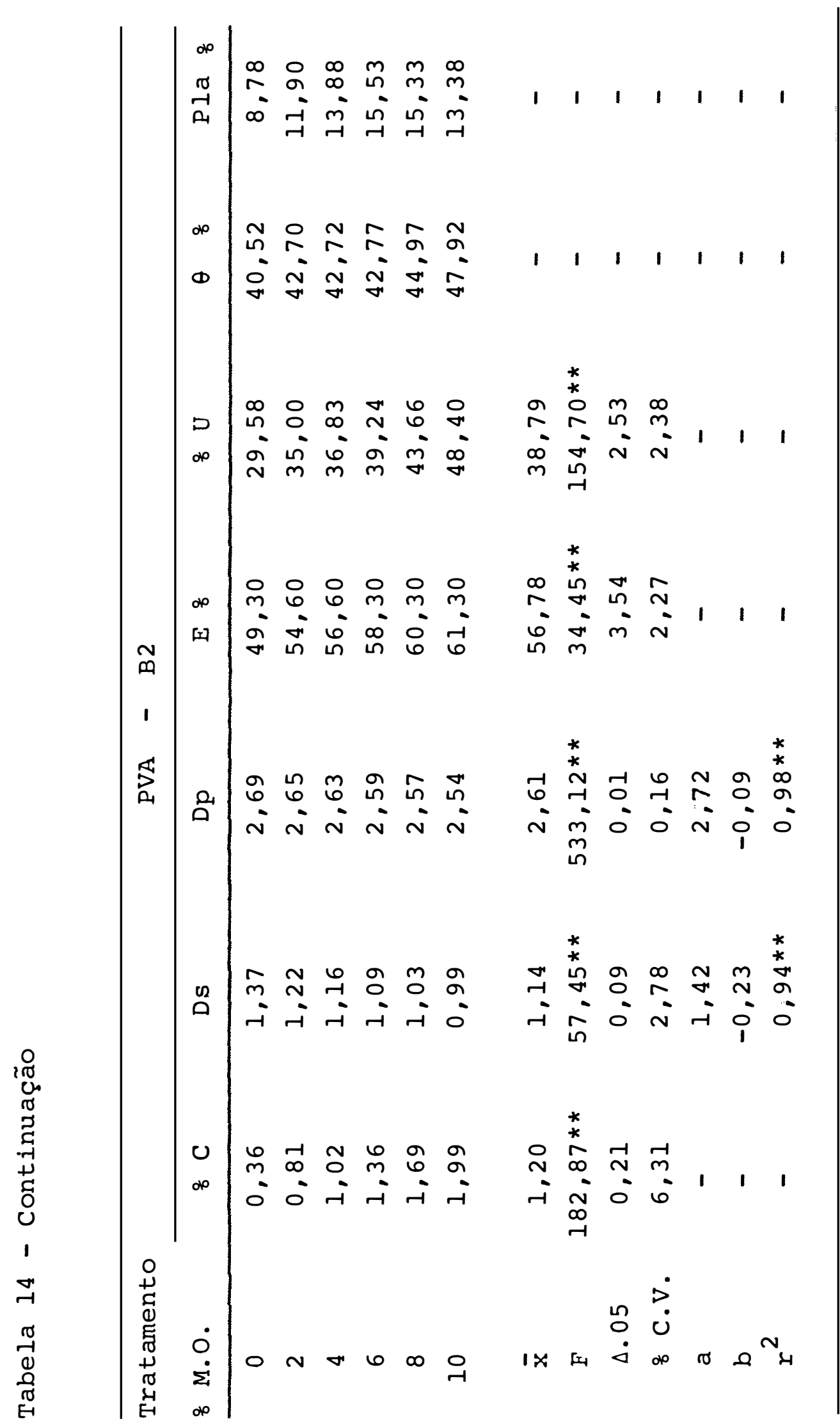


Comparando os resultados para os dois horizontes do Latossolo Roxo, observa-se que a densidade do solo no B2 foi ligeiramente menor que no Ap, enquanto que a densidade das partículas apresentou valores mais elevados, apesar de que a maior contribuição percentual do carbono tenha ocorrido no B2. Isto tem como consequência que a contribuição indireta da matéria orgânica é mais marcante no B2, pois, enquanto contribuiu para diminuir a densidade do solo (efeitos direto e indireto), não foi suficiente para diminuir a densidade das partículas na mesma proporção (efeito direto). o resultado final é que a porosidade total é nitidamente maior no horizonte B2. Embora a porosidade total seja nitidamente maior nesse horizonte, a porosidade livre de água (Pla) apresenta valores variáveis para os diversos tratamentos dos dois horizontes do Latossolo Roxo. O valor "Pla" foi calculado em função do teor de água da amostra na ocasião da determinação da densidade do solo; consequentemente é uma indicação da variação da distribuição de poros por tamanho entre os tratamentos estudados. Os valores do teor de água dos tratamentos dos cinco horizontes é apresentado na Figura 11.

E visível a tendência. O teor de água $\frac{0}{0}$ de peso ( $U$ \%) na amostra de todos os horizontes, tende a aumentar com o aumento de matéria orgânica aplicada. Entretanto, conforme se observa nas Tabelas 13 e 14 a densidade do solo ten- 
80 .

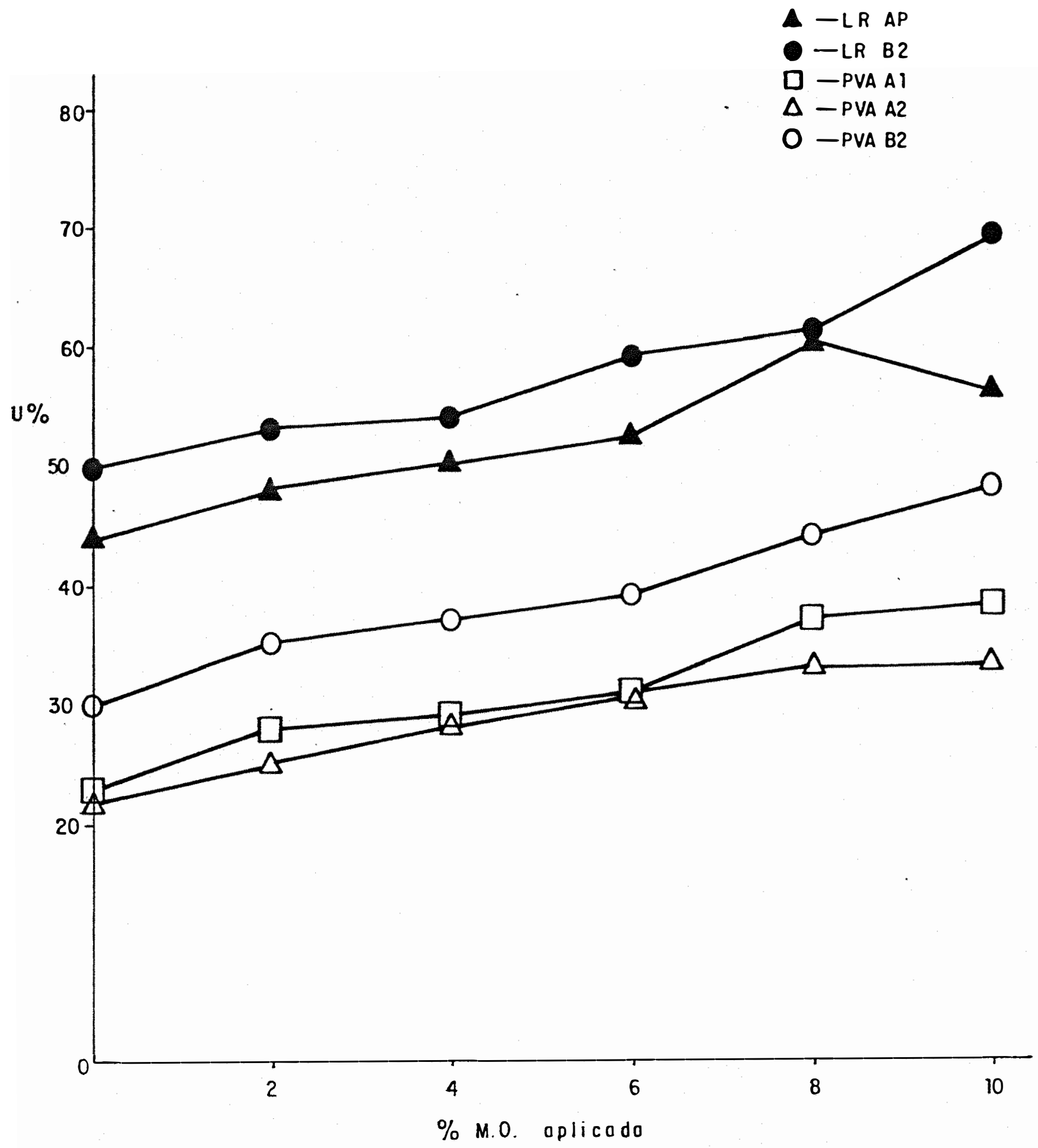

Figura 11 - Efeito do teor de matéria orgânica no teor de água em que a densidade do solo foi determinada. 
de a diminuir e, portanto, o teor de água em $q$ de volume $(\theta)$ tende a diminuir, também, com o aumento da matéria orgânica.

Esses dados e o relacionamento que refletem, mostram a importância de se expressar o teor de um componente do solo em relação ao seu volume, considerando a densidade do solo.

Analisando as variações nas duas densidades , para os 3 horizontes do Podzólico Vermelho Amarelo, verifi cou-se que a densidade do solo é menor e a densidade das partículas maior no horizonte B2, apesar de maior teor percen tual de \& $\mathrm{C}$ ser encontrado no $\mathrm{Al}$. Isto tem como consequência que a contribuição da matéria orgânica foi mais marcante no B2 do que no Al e A2, pois, enquanto contribuiu para diminuir a densidade do solo não foi suficiente para diminuir a den sidade das partículas nas mesmas proporções. Como o teor mais elevado de matéria orgânica ocorre no Al, a contribuição da matéria orgânica foi mais marcante no B2 por se verificar menores valores na densidade do solo e na densidade das partículas e maior porosidade do que no A2.

A comparação entre as médias dos tratamentos através do teste de Tukey (tabelas citadas) mostra diferenças altamente significativas em todos os horizontes. Essas dife- 
renças, observadas na comparação entre as médias dos trata mentos, mostra que há um determinado incremento mínimo de matéria orgânica aplicada para que a diferença entre os efeitos da matéria orgânica sobre os parâmetros seja significativa.

Assim, comparando os tratamentos com o valor $\triangle .05$ (teste de Tukey), constatou-se que os resultados da densidade das partículas foram altamente significativos para os dois horizontes, Ap e. B2 do Latossolo Roxo, enquanto que a densidade do solo apresentou resultados não significativos nos tratamentos $0 \& \operatorname{com} 28 ; 28 \operatorname{com} 48 ; 48 \operatorname{com} 6 \% ; 6 \%$ com $10 \&$ e $10 \&$ com 8 \& de matéria orgânica no Ap e nos tratamentos $28 \operatorname{com} 0 \&$ e $48 ; 0 \& \operatorname{com} 48 ; 48 \operatorname{com} 68 ; \quad 68$ com $10 \%$ e $8 \%$ com $10 \%$ com $8 \%$ de matéria orgânica no horizonte B2 do Latossolo Roxo. A porosidade total apresentou valores não significativos nos tratamentos $8 \& \operatorname{com} 10 \% ; 6 \%$ com $10 \% ; 48 \operatorname{com} 6 \% ; 28 \operatorname{com} 4 \%$ e $0 \%$ com $2 \%$ de matéria orgânica no Latossolo Roxo, e, no horizonte B2, foi verifi cado valores significativos nos tratamentos $8 \% \operatorname{com} 0 \% ; 4 \%$ e $28 ; 10 \% \operatorname{com} 0 \% ; 4 \&$ e $28 ; 6 \% \operatorname{com} 2 \%$ de matéria orgânica.

Analisando os resultados dos três parâmetros, no Podzólico Vermelho Amarelo, verificou-se diferenças sig - 
nificativas na densidade do solo entre todos os tratamentos no A1, como também no A2, exceto entre os tratamentos $2 \%$ e $4 \%, 6 \%$ e $4 \%$ e $6 \%$ e $10 \%$ de matéria orgânica e no B2 exceto entre tratamento $2 \%$ e $4 \%$; $6 \%$ e $4 \%$; 8 \% $6 \%$ e $10 \%$ e 8 \& de matéria orgânica.

Os resultados da densidade das partículas foram significativos em todos os tratamentos no A2 e no B2,e, no Al, apenas entre os tratamentos $4 \frac{8}{6} \operatorname{com} 6 \%, 8 \%$ e $10 \%$, $0 \% \operatorname{com} 8 \%$ e $10 \%$ de matéria orgânica.

Os resultados não significativos na porosi dade total foram verificados nos tratamentos $10 \%, 8 \%$ e $6 \%$ com 8 \% , 6 \% e 4 \% de matéria orgânica no A2 e $10 \%, 8 \%$ e $6 \%$ e $4 \%$ com os tratamentos $8 \%$ e $6 \%, 6 \%, 4 \%$ e $2 \%$ de matéria orgânica no B2.

E nas relações entre massa e volume que se notam mais claramente os efeitos direto e indireto da matéria orgânica no solo. No caso da densidade das partículas há apenas o efeito direto resultante da presença da maté ria orgânica como componente. E, no caso da densidade do solo, há, além do efeito da presença, o efeito na estrutura e estabilidade da estrutura pela ação agregante nas partículas minerais. Este relacionamento está ilustrado nas Figu - 
ras 12, 13, 14,15 e 16. Observa-se que o coeficiente angular da equação de regressão para Dp vs ơ C é semelhante para todos os horizontes. Aceitando, como se deve, que a matéria orgânica tem um efeito direto e de correlação altamente significativa com a Dp, pode-se tomar o coeficiente angular como medida desse efeito. Considerando-se que o valor da densidade da partícula é componente intrínseco da densidade do solo, modificado pela disposição espacial das partículas (da qual disposição resulta a porosidade), como se pode perceber comparando as expressões matemāticas correspondentes:

$$
\mathrm{Dp}=\frac{\mathrm{Mp}}{\mathrm{Vp}} ; \quad \mathrm{Ds}=\frac{\mathrm{Mp}}{\mathrm{Vp}+\mathrm{Ve}}
$$

onde:

Mp = massa das partículas

$\mathrm{Vp}=$ volume das partículas

Ve = volume dos poros,

é razoável dizer que a diferença entre os coeficientes angulares das equaçōes de regressão para \& C e cada uma das densidades, é uma representação do efeito indireto da matéria orgânica na densidade do solo. Esta afirmação de casualidade é feita pelo fato de se observar que os coeficientes angulares para a regressão da Ds sobre \& C não são semelhantes para os 5 horizontes, indicando que há uma variação na estru - 
85.

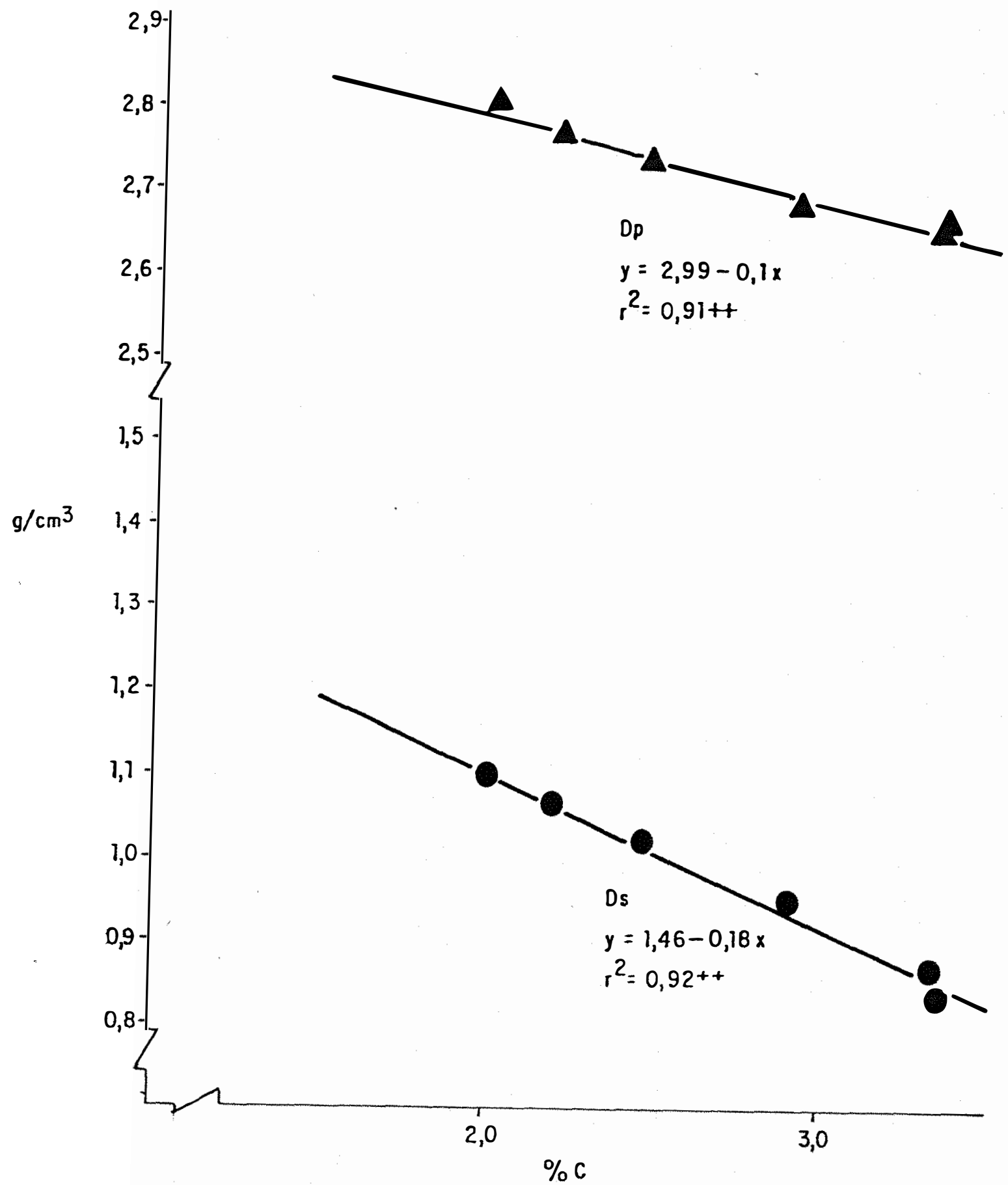

Figura 12 - Densidade do solo (Ds) e Densidade das partículas (Dp) em relação ao \& C após o período de incuba ção da matéria orgânica adicionada ao horizonte Ap do Latossolo Roxo. 


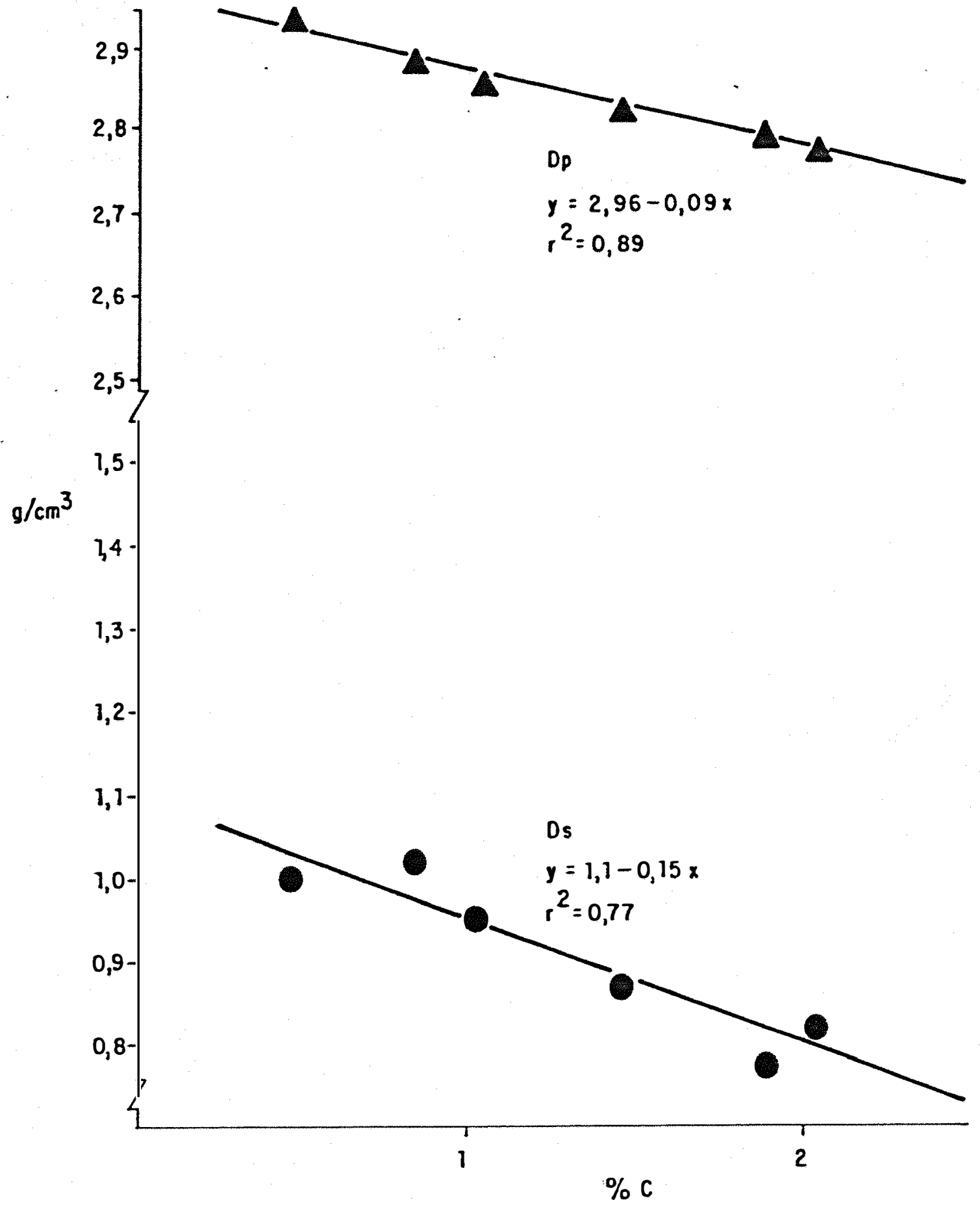

Figura 13 - Densidade do solo (Ds) e Densidade das partículas (Dp) em relação ao \& $C$ após o período de incuba ção da matéria orgânica adicionada ao horizonte B2 do Latossolo Roxo. 


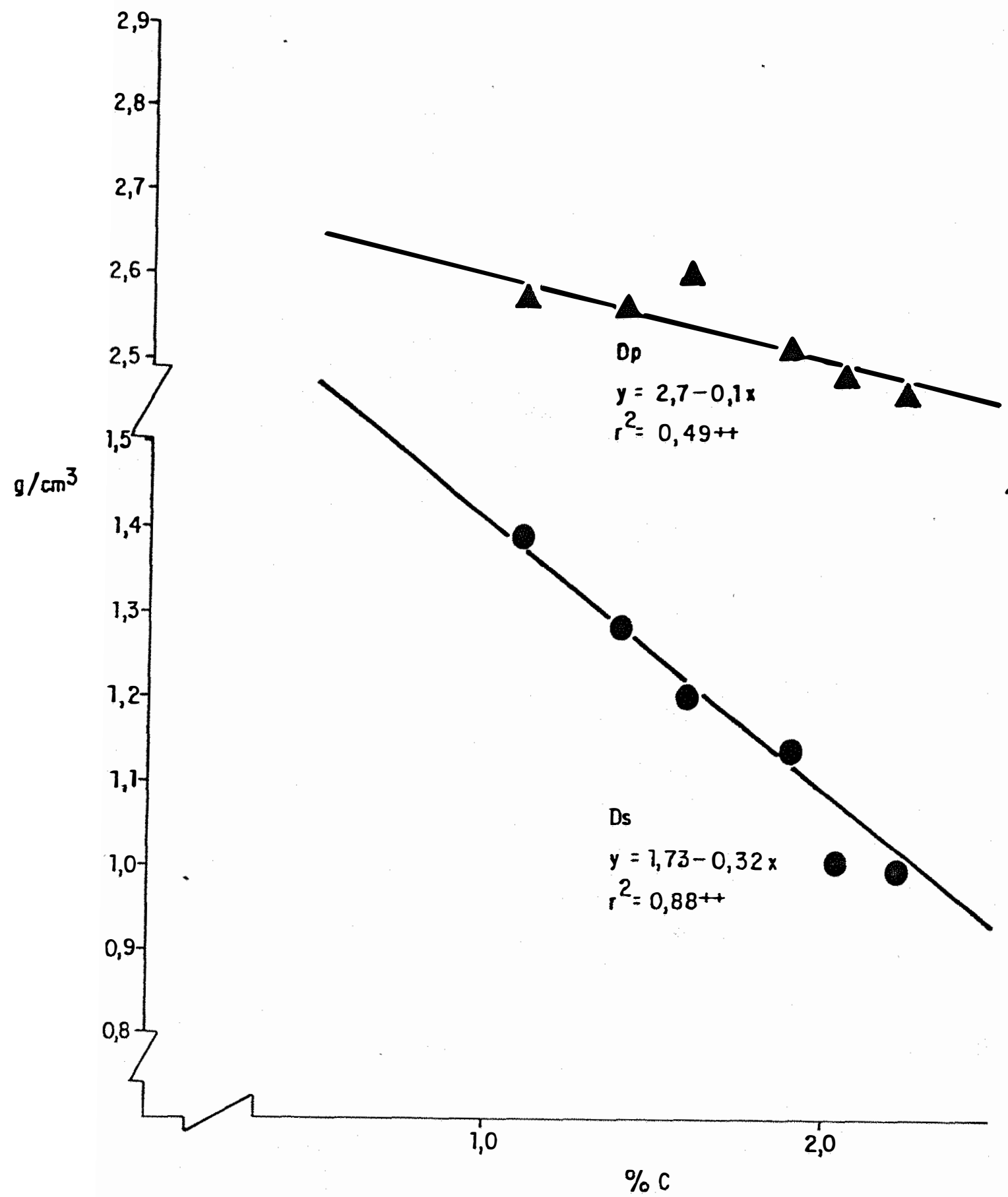

Figura 14 - Densidade do solo (Ds) e Densidade das partículas (Dp) em relação ao : $C$ após o período de incubação da matēria orgânica adicionada ao horizonte Al do Podzólico Vermelho-Amarelo. 
88.

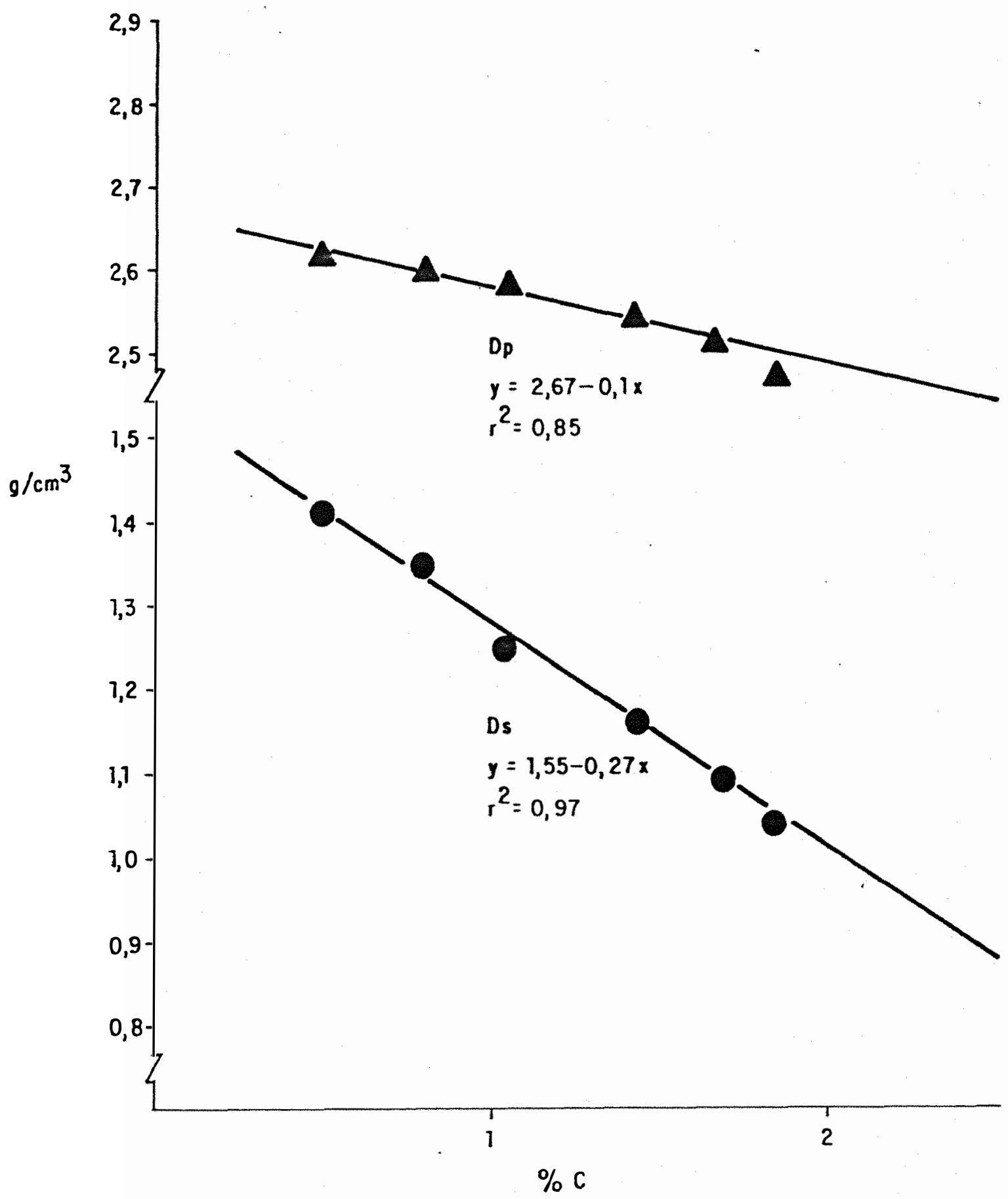

Figura 15 - Densidade do solo (Ds), Densidade das partículas (Dp) em relação ao \& C após o período de incubação da matéria orgânica adicionada ao horizonte A2 do Podzólico Vermelho-Amarelo. 


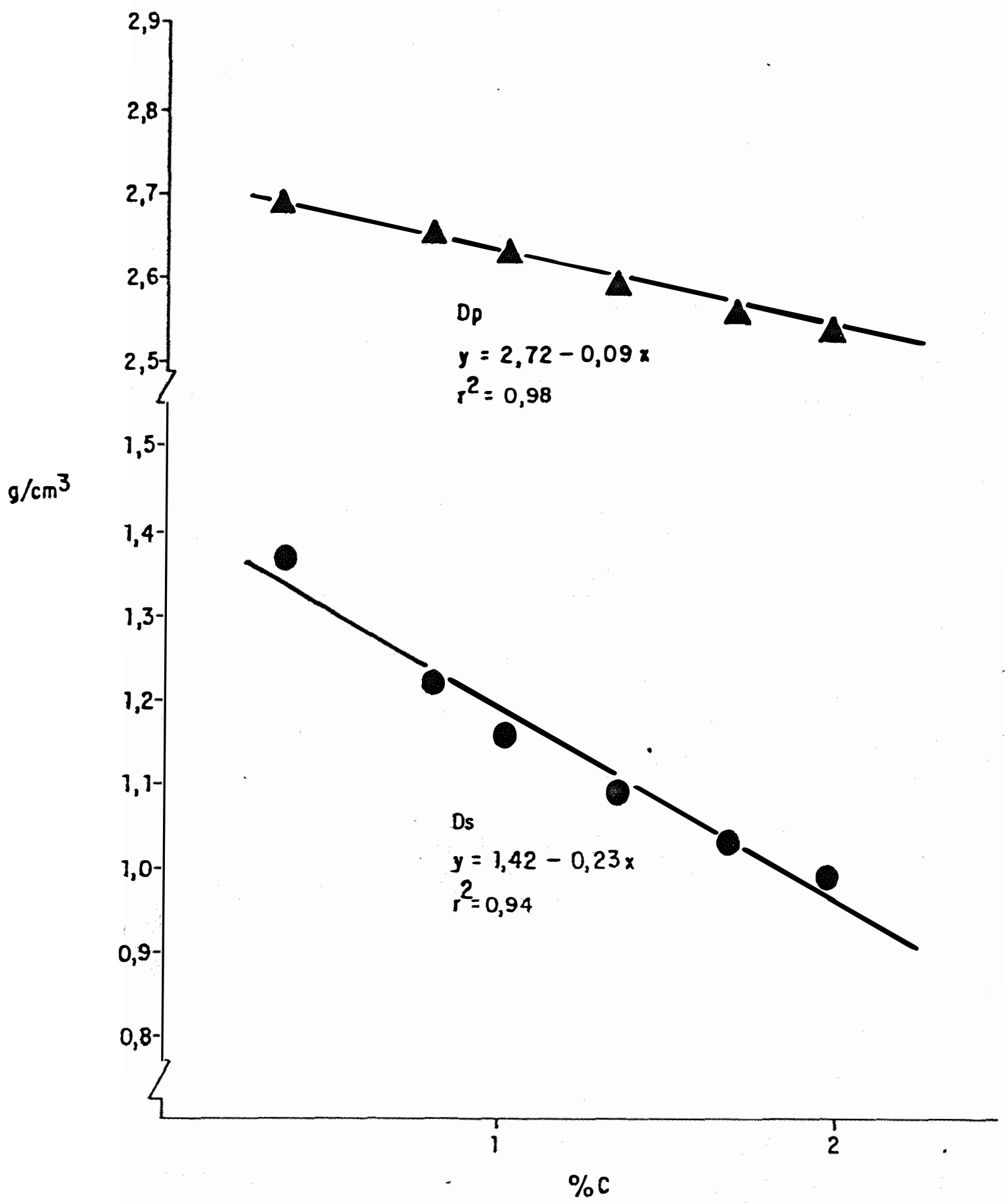

Figura 16 - Densidade do solo (Ds) e Densidade da partícula (Dp) em relação ao \& C após o período de incubação da matéria orgânica, adicionada ao horizonte B2 do Podzólico vermelho-Amarelo. 
tura de um para outro. A expressão calculada para porosidade total ( 8 E) reflete esse mesmo efeito (ver Tabelas 13 e 14).

A contribuição direta da matéria orgânica para a porosidade total é desprezível, pois em nenhum dos tratamentos aplicados aos cinco horizontes a variação no teor de matéria orgânica, resultante dos tratamentos, é igual ou superior aos acréscimos na porosidade total calculada.

Esse relacionamento é, de certa forma, reco nhecido pelos autores. Resultados apresentados por REEVE et alii (1973) indicam que, conhecendo-se a densidade do solo, juntamente com uma avaliação aproximada da granulometria,pode-se estimar, dentro de um erro aceitável, a distribuição de tamanho de poros, capacidade de ar e teor de água a baixas sucções.

Esses efeitos da matéria orgânica já foram anteriormente explicados por BAVER (1968), que, em diversos trabalhos, e notadamente em seu clássico livro "Soil Physics", expôs que a agregação e estabilidade da estrutura provêm de: (a) ação mecânica de ligação dada por células e filamentos dos organismos e (b) cimentação pelos produtos da síntese microbiana. 
Conclui-se, do exposto, que a matéria orgânica tem efeito direto sobre as duas densidades e também um efeito indireto sobre a densidade do solo. Consequentemente, afeta a porosidade total numa ordem crescente e numa relação direta com o teor de matéria orgânica aplicada.

4.4. Experimento 4: Efeito do teor de matéria orgânica na retenção de água a diferentes potenciais.

A capacidade de retenção de água sofreu variações pela adição de diferentes teores de matéria orgânica às amostras dos cinco horizontes das duas séries de solos estudados, como se pode constatar nas Tabelas 15 e 16 . Foi observado, também, que o efeito da matéria orgânica já havia se manifestado antes da sua decomposição, conforme pode ser verificado na Tabela 4, já apresentada. Os teores de água estabelecidos para a irrigação pelo método TSFM. (ver. item 3.2.2.2.) foram relacionados às respectivas tensões extrapolando-se esses valores das curvas de retenção, representadas nas Figuras de n̊s 17 a 21. Para essa extrapolação, considerou-se que, para a tensão zero corresponderia um teor de água igual ao valor da porosidade total (valor E 8 das Tabelas 13 e 14). As tensões e os correspondentes teores de água utilizados para irrigação são apresentados na Tabela 17 . 

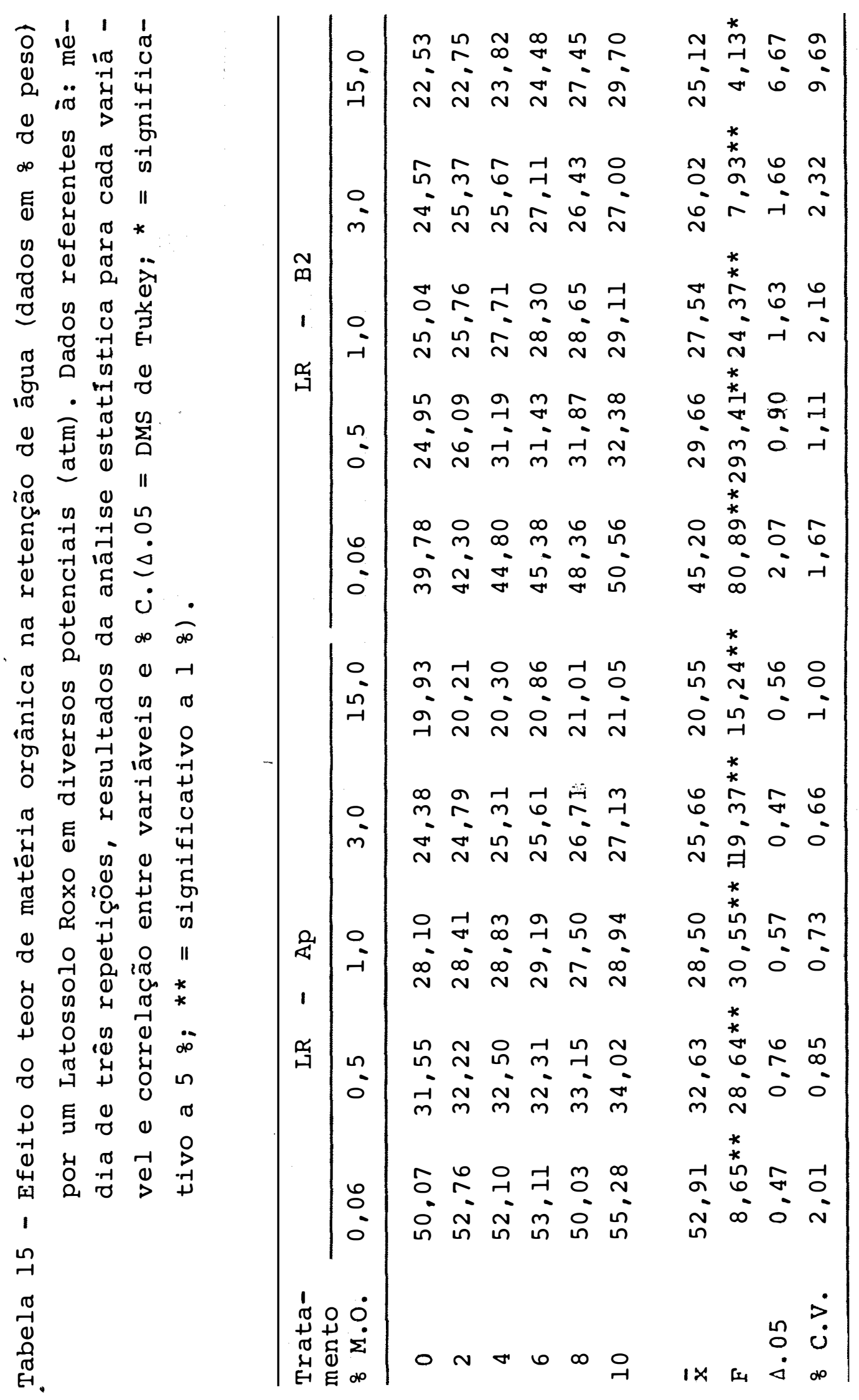
Ṭabela 16 - Efeito do teor de matéria orgânica na retenção de. água (dados em ơ de peso) por um Podzólico Verme1ho-Amarelo em diversos potenciais (atm). Dados referentes à: média de três repetições, resultados da análise estatística para cada variável e correlação entre variáveis e \& $C .\{\Delta .05=$ DMS de Tukey; $*$ = significativo a $5 \%$ e $* *$ = significativo a 18 ).

\begin{tabular}{cccccc}
\hline \multirow{2}{*}{$\begin{array}{c}\text { Tratamento } \\
\text { M.0. }\end{array}$} & \multicolumn{5}{c}{ PVA - Al } \\
\cline { 2 - 6 } 0 & 32,54 & 18,26 & 13,96 & 10,25 & 6,76 \\
\hline 2 & 36,82 & 19,23 & 14,77 & 11,18 & 7,26 \\
4 & 37,68 & 19,09 & 15,27 & 11,84 & 8,02 \\
6 & 40,44 & 19,58 & 16,19 & 12,76 & 8,78 \\
8 & 41,42 & 21,16 & 16,83 & 13,73 & 9,36 \\
10 & 42,96 & 22,66 & 18,17 & 14,43 & 11,17 \\
\hline $\bar{x}$ & & & & & \\
F & 38,65 & 20,00 & 15,87 & 12,39 & 8,56 \\
$\Delta .05$ & $92,45 *$ & $14,59 * *$ & $20,50 *$ & $24,89 * *$ & $120,74 *$ \\
8 C.V. & 1,86 & 2,00 & 1,59 & 1,49 & 0,69 \\
& 1,76 & 3,66 & 3,67 & 4,39 & 2,94
\end{tabular}

(Continua) 
94.

Tabela 16 - Continuação

\begin{tabular}{cccccc}
\hline Tratamento & \multicolumn{5}{c}{ PVA - A2 } \\
\cline { 2 - 6 } \% M.O. & 0,06 & 0,5 & 1,0 & 3,0 & 15,0 \\
\hline 0 & 30,60 & 18,32 & 12,68 & 9,56 & 6,33 \\
2 & 34,39 & 19,37 & 13,31 & 10,21 & 6,81 \\
4 & 35,47 & 20,66 & 13,69 & 10,77 & 9,25 \\
6 & 37,42 & 21,07 & 14,72 & 11,42 & 9,80 \\
8 & 35,82 & 18,57 & 15,48 & 12,14 & 10,52 \\
10 & 38,99 & 19,64 & 15,64 & 12,94 & 11,24 \\
& & & & & \\
$\bar{x}$ & 35,48 & 19,61 & 14,25 & 11,18 & 9,00 \\
F & $59,39 * *$ & $39,75 * *$ & $42,95 * *$ & $527,47 * *$ & $1163,32 * *$ \\
$\Delta .05$ & 1,78 & 0,83 & 0,88 & 0,26 & 0,27 \\
\% C.V. & 1,84 & 1,54 & 2,25 & 0,84 & 1,13
\end{tabular}

$$
\text { PVA - B2 }
$$

$\begin{array}{lccccc}0 & 33,29 & 22,59 & 20,36 & 17,86 & 14,47 \\ 2 & 35,92 & 23,78 & 21,64 & 18,86 & 14,84 \\ 4 & 38,23 & 24,37 & 22,34 & 19,38 & 15,11 \\ 6 & 39,93 & 25,42 & 23,64 & 20,29 & 15,64 \\ 8 & 40,71 & 25,95 & 23,12 & 20,67 & 18,81 \\ 10 & 41,45 & 27,46 & 24,32 & 21,68 & 18,89 \\ \bar{x} & & & & & \\ \text { F } & 37,87 & 24,93 & 22,57 & 19,79 & 16,30 \\ \Delta .05 & 8,21 * * & 108,79 * * & 64,35 * * & 95,44 * * & 97,00 * \star \\ \therefore \mathrm{C} . \mathrm{V} . & 5,44 & 0,78 & 0,85 & 0,67 & 0,97 \\ & 5,23 & 1,15 & 1,38 & 1,22 & 2,18\end{array}$




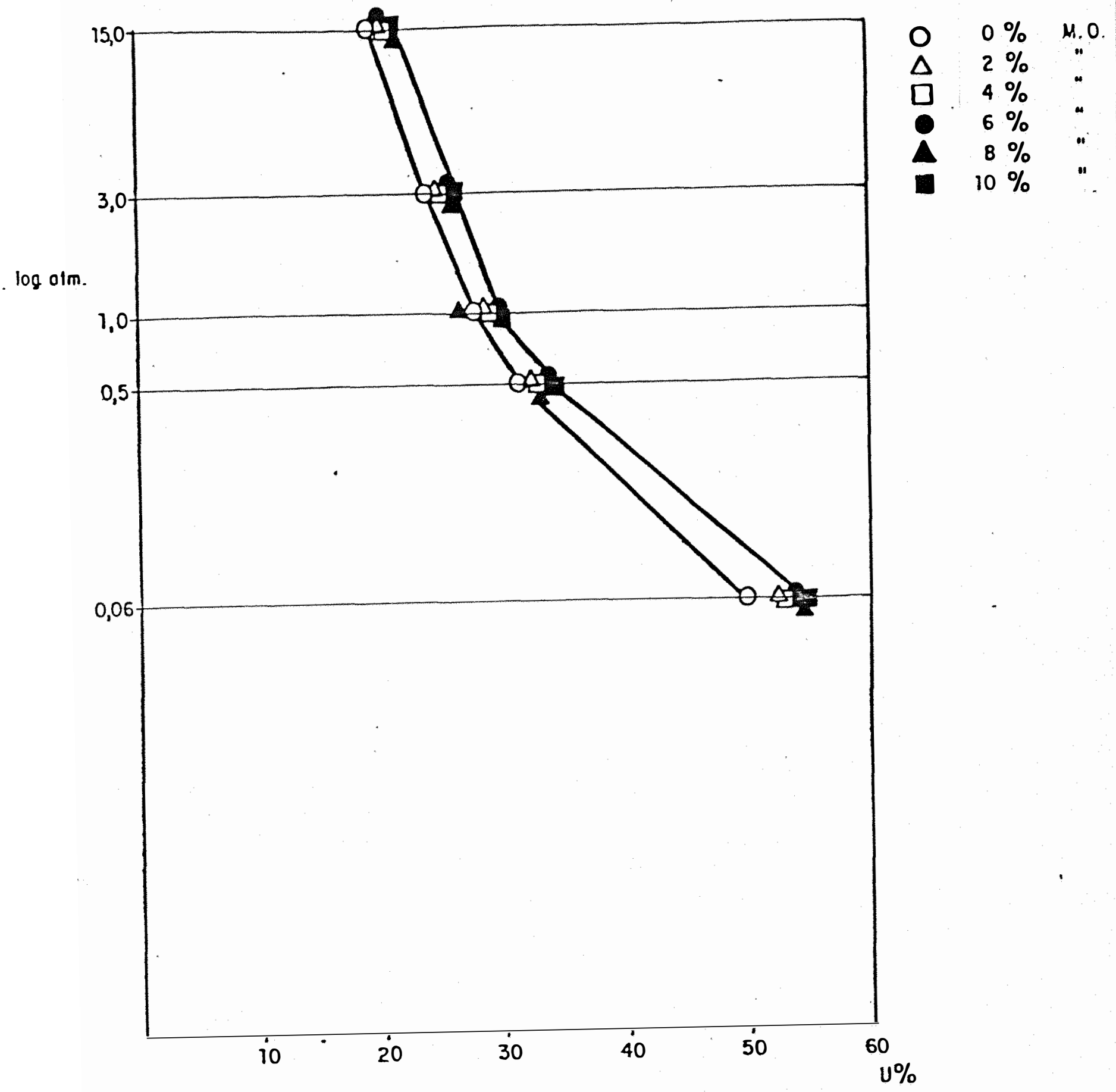

Figura 17 - Curvas características de retenção de água para amostras do horizonte Ap do Latossol Roxo, mostrando o efeito da quantidade de matéria orgâ nica aplicada nos diversos tratamentos. 


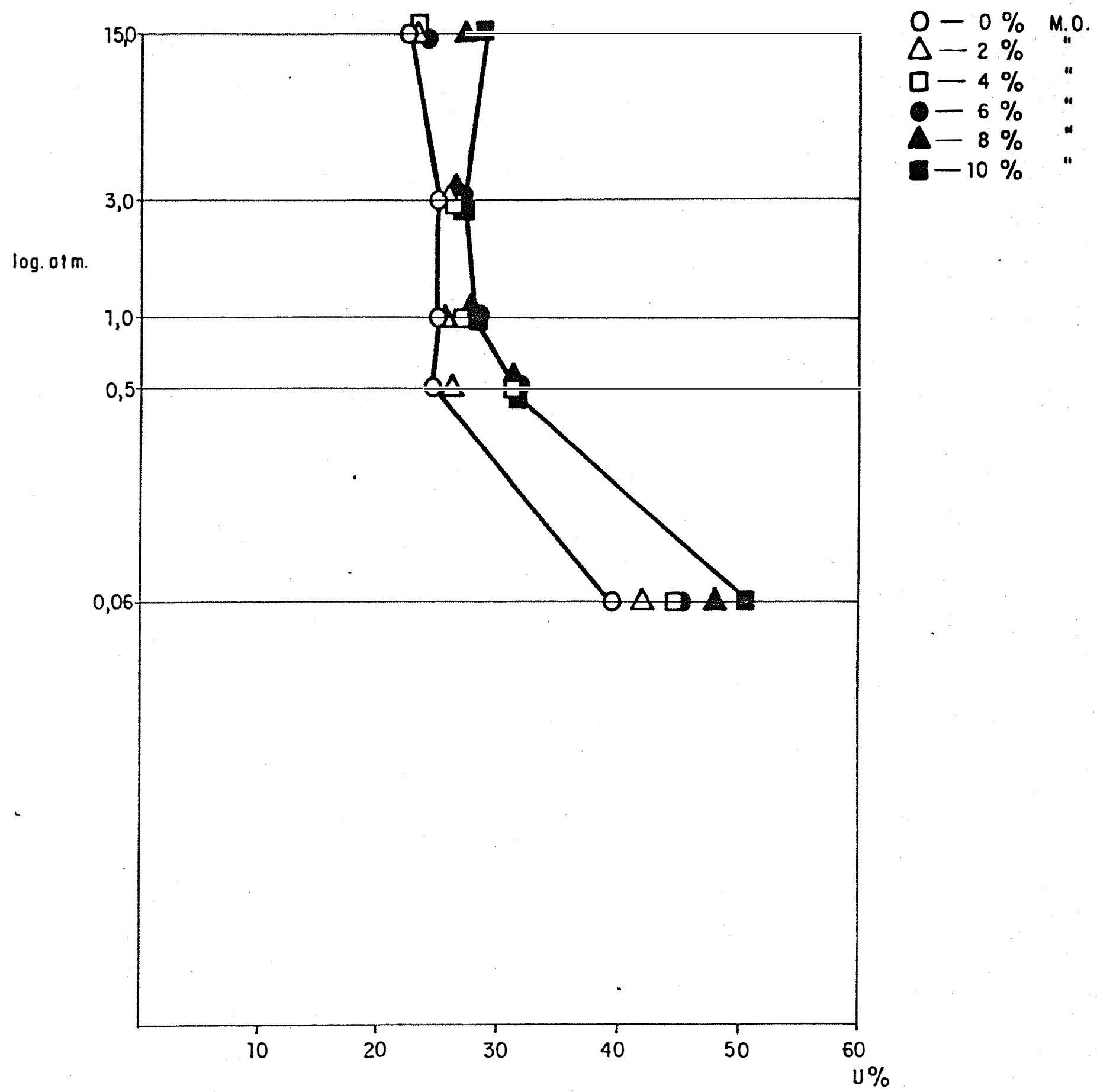

Figura 18 - Curvas caracterísțicas de retenção de água para amostras do horizonte B2 do Latossol Roxo, mostrando o efeito da quantidade de matéria orgâ nica aplicada nos diversos tratamentos. 


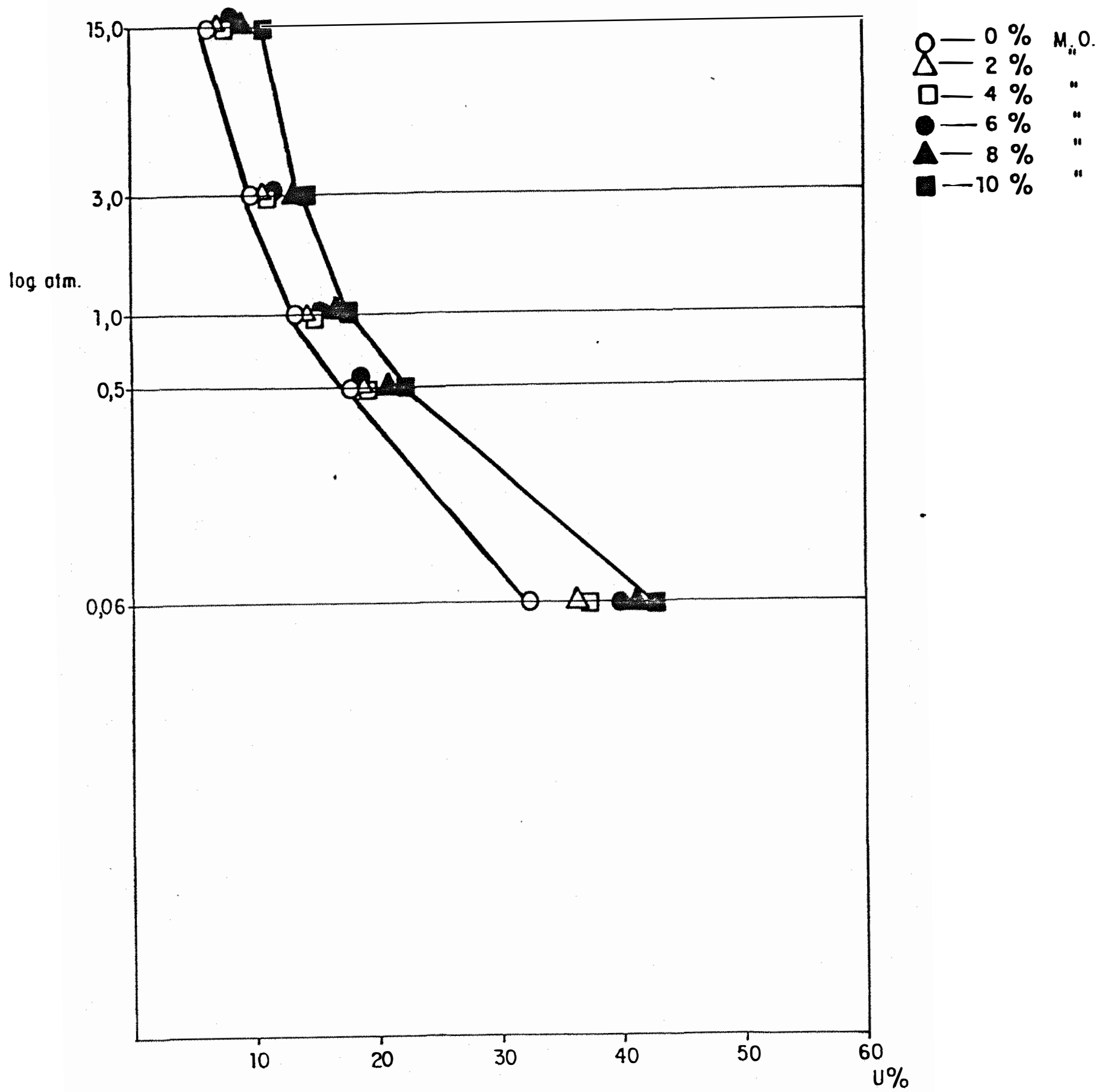

Figura 19 - Curvas características de retenção de água para amostras do horizonte Al do Podzólico VermelhoAmarelo, mostrando o efeito da quantidade de matéria orgânica aplicada nos diversos tratamentos. 


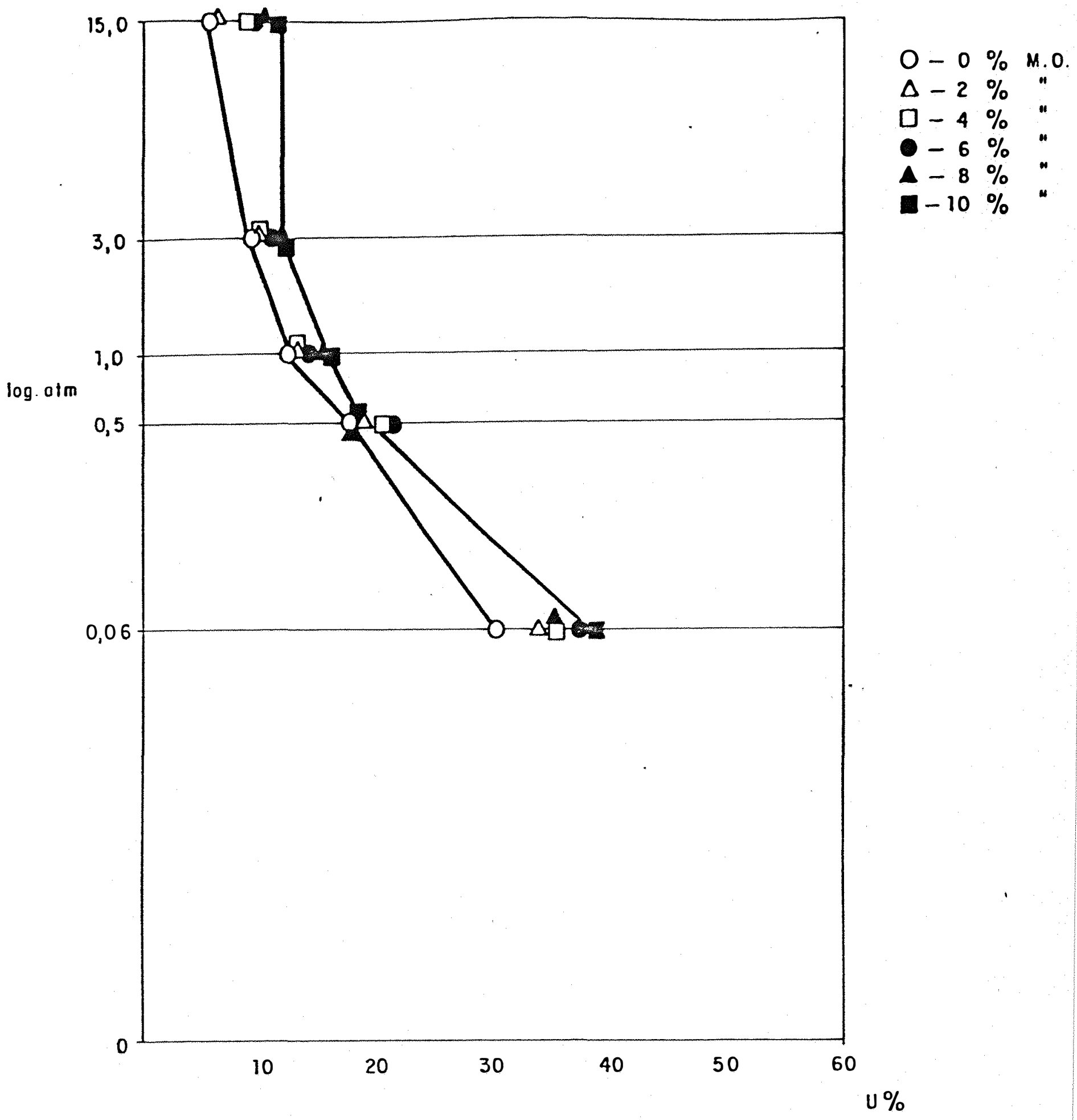

Figura 20 - Curvas características de retenção de água para amostras do horizonte. A2 do Podzólico VermelhoAmarelo, mostrando o efeito da quantidade de matéria orgânica aplicada nos diversos tratamentos. 


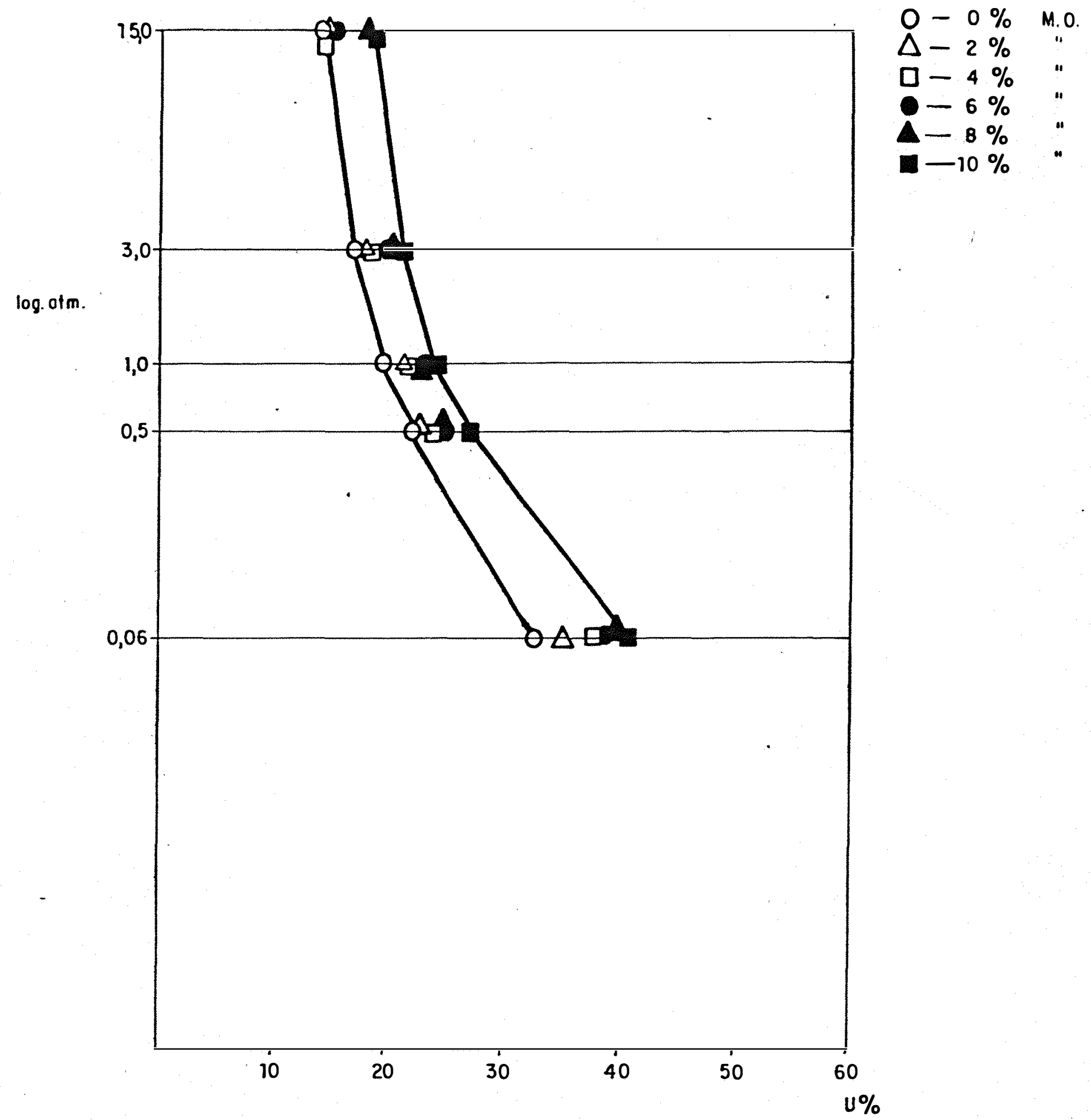

Figura 21 - Curvas características de retenção de água para amostras do horizonte B2 do Podzólico VermelhoAmarelo, mostrando o efeito da quantidade da matéria orgânica aplicada nos diversos tratamentos. 


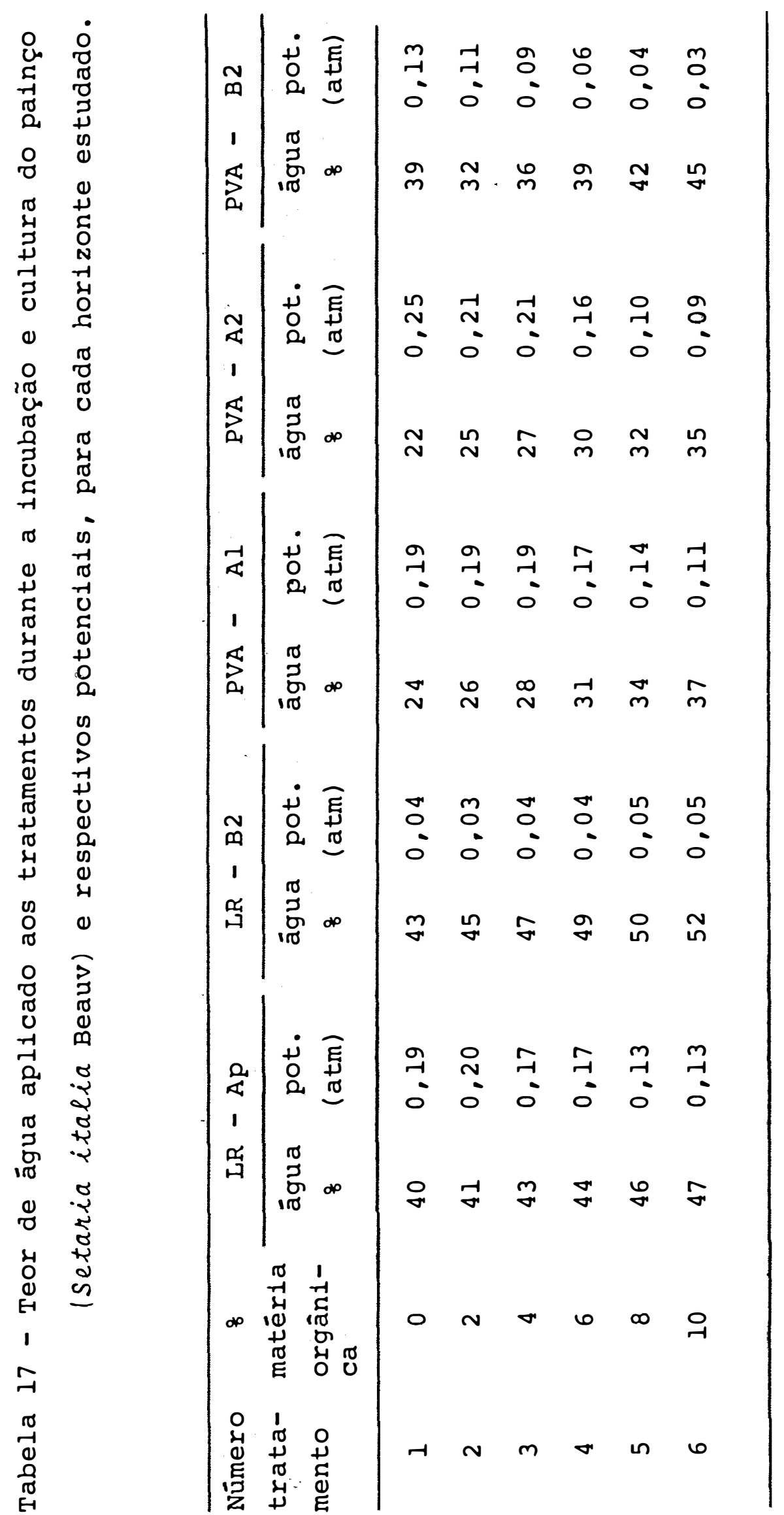


Nota-se que em todos os horizontes ocorreu um aumento no teor de água aplicado aos tratamentos com o aumento da dosagem de matéria orgânica e que ocorreu, concomitantemente, uma diminuição da tensão. A única exceção foi para as amostrás do horizonte B2 do Latossol Roxo.

E conhecida a capacidade de retenção de água da matēria orgânica. Sua elevada superfície específica e a presença de cargas na fração húmica contribuem para que se encontrem valorés muito mais elevados do que para a fração mineral. Recentemente, MARCOS $(1983)^{*}$ obteve os seguintes resultados para um solo turfoso: perda ao rubro 77,1 \%; carbo no (\& C) 39,9 ; ; matēria orgânica (\% M.0.) 67,8 \& e retenção de água a $0,1 \mathrm{~atm}=819,48 ; 0,33 \mathrm{~atm}=469,38 ; 1,0 \mathrm{~atm}=$ $290,9 \% ; 5,0 \mathrm{~atm}=313,8 \%$ e $15,0 \mathrm{~atm}=277,8 \%$. Neste estudo verificou-se um efeito significativo na capacidade de retenção de água com o aumento do teor de matéria orgânica aplicada em todos os horizontes submetidos a diferentes tensões.

Para os dois horizontes do LR (Tabela 15) submetidos às tensões $0,06 \mathrm{~atm}, 0,5 \mathrm{~atm}$ e $1,0 \mathrm{~atm}$, a retenção de água no Ap foi maior que no B2 enquanto que, a retenção a 15 atm apresentou-se maior no B2. Esta variação no efeito de tratamentos idênticos de matéria orgânica aplicados a amostras de horizontes distintos deve ser interpretada como sen-

* Comunicação particular. 
do resultado do efeito indireto da matéria orgânica. Sabe-se que a baixas tensões a estrutura afeta significativamente a retenção de água, No caso da tensão a 0,06 atm a influência da matéria orgânica foi mais acentuada no horizonte B2, de tal modo que a retenção no tratamento $10 \%$ de matéria orgâ nica aproximou-se da apresentada pelo horizonte Ap no tratamento testemunha ( 0 \& de matéria orgânica). Para as tensões mais elevadas, 15 atm por exemplo, constata-se o efeito direto da matéria orgânica, isto é, ocorre aumento no teor de colóides concomitantemente com o aumento da quantidade de matéria orgânica aplicada. Este efeito, embora marcante,é, no entanta', relativamente menor que o observado para baixas tensões. Isto porque o teor de água retido nos poros é mais elevado que o retido por adsorção à superfície dos colóides.

Comparando-se os resultados para os horizontes do PVA, constata-se que a retenção de água às várias tensões foi maior no B2 do que nos horizontes Al e A2, exceto para 0,06 atm de tensão em que a retenção foi aproximadamente igual no Al. e no B2.

Examinando-se os dados da Tabela 16 constatase que,para os horizontes do PVA, o efeito indireto da matéria orgânica foi também mais acentuado. 
4.5. Experimento 5: Efeito do teor de matéria orgânica na evaporação da água no solo

Embora nada tenha sido comentado na revisão de literatura sobre o efeito da matéria orgânica na evaporação da água no solo, os resultados apresentados nas Tabelas 18, $19,20,21$ e 22 ,mostram que a incorporação de crescentes teores de matéria orgânica às amostras dos 5 horizontes das duas séries de solos provocou modificações significativas na evaporação da água nio solo durante o período de incubação.A evaporação foi determinada pelo peso e correspondem ao peso de água adicionada aos tratamentos para mantê-los com o teor estipulado na Tabela 4.

Observou-se um aumento gradual na evaporação com a elevação do teor de matéria orgânica e,com o prolonga mento do tempo de incubação, constatou-se diminuição brusca na evaporação da água, como se pode observar na $4 \stackrel{a}{0}$ e 20 a reposições de água e um aumento significativo na 9a., 11., 15 a e 21. reposições de água para as duas sēries de solos. Estas variações na evaporação estão relacionadas com modificações na temperatura e na estrutura do solo.

A comparação entre as medidas dos tratamentos através do teste de Tukey (tabelas citadas), mostra que o efeito da matéria orgânica na evaporação foi mais significativa 

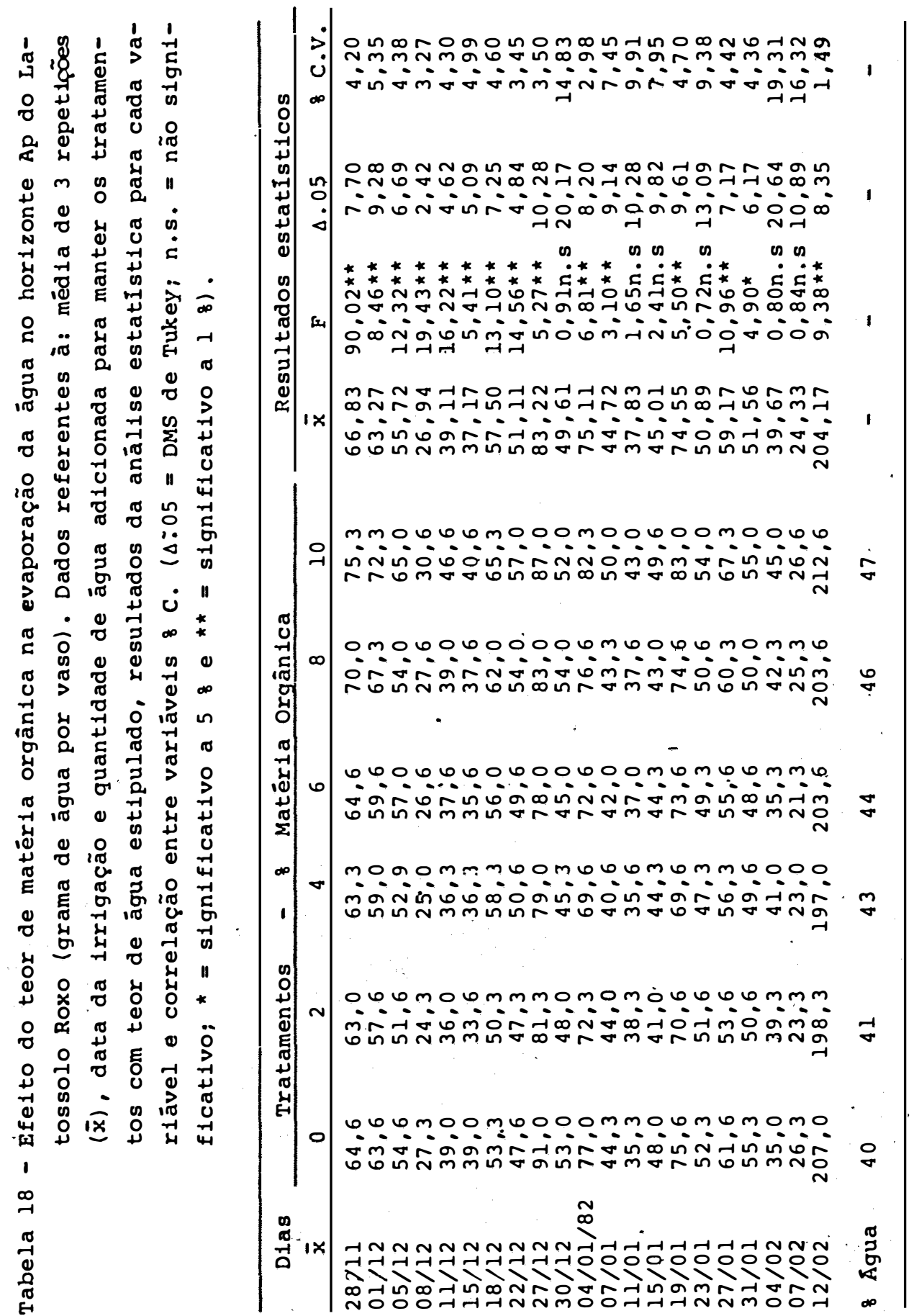


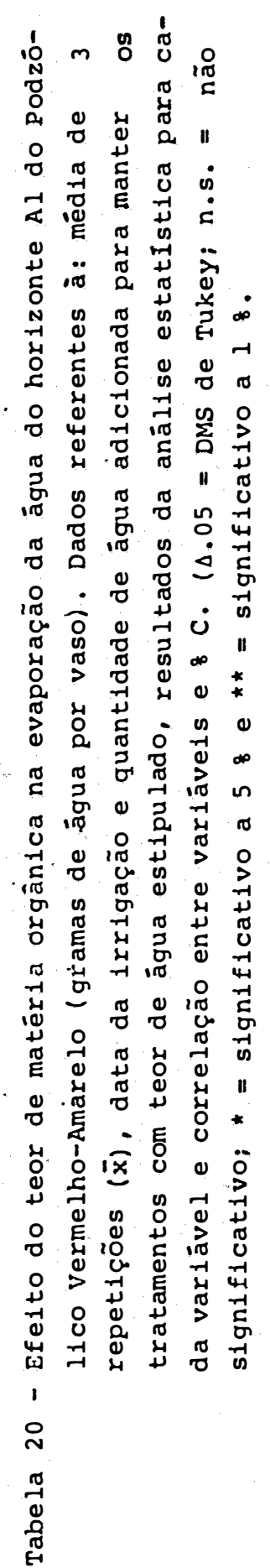

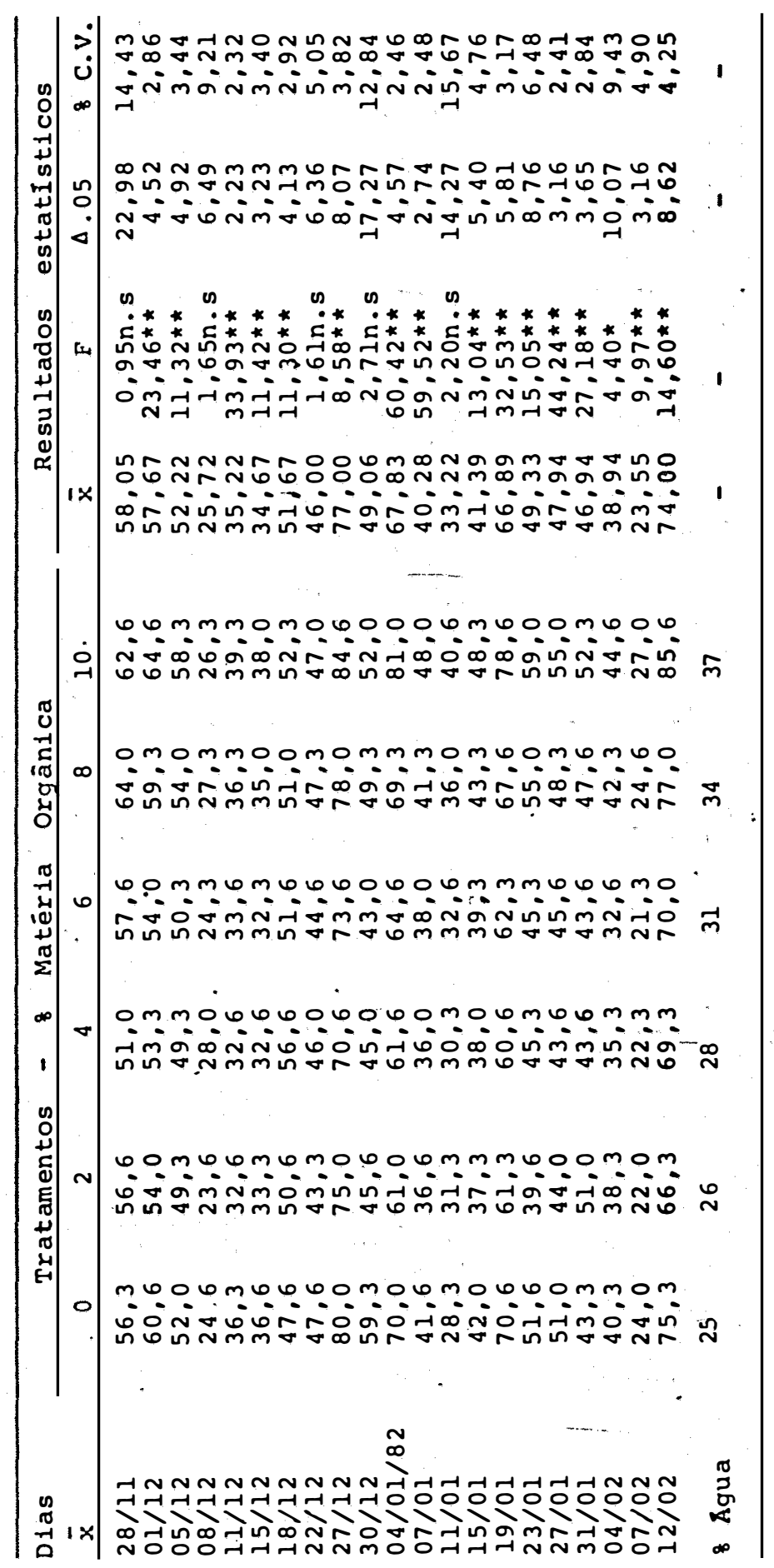




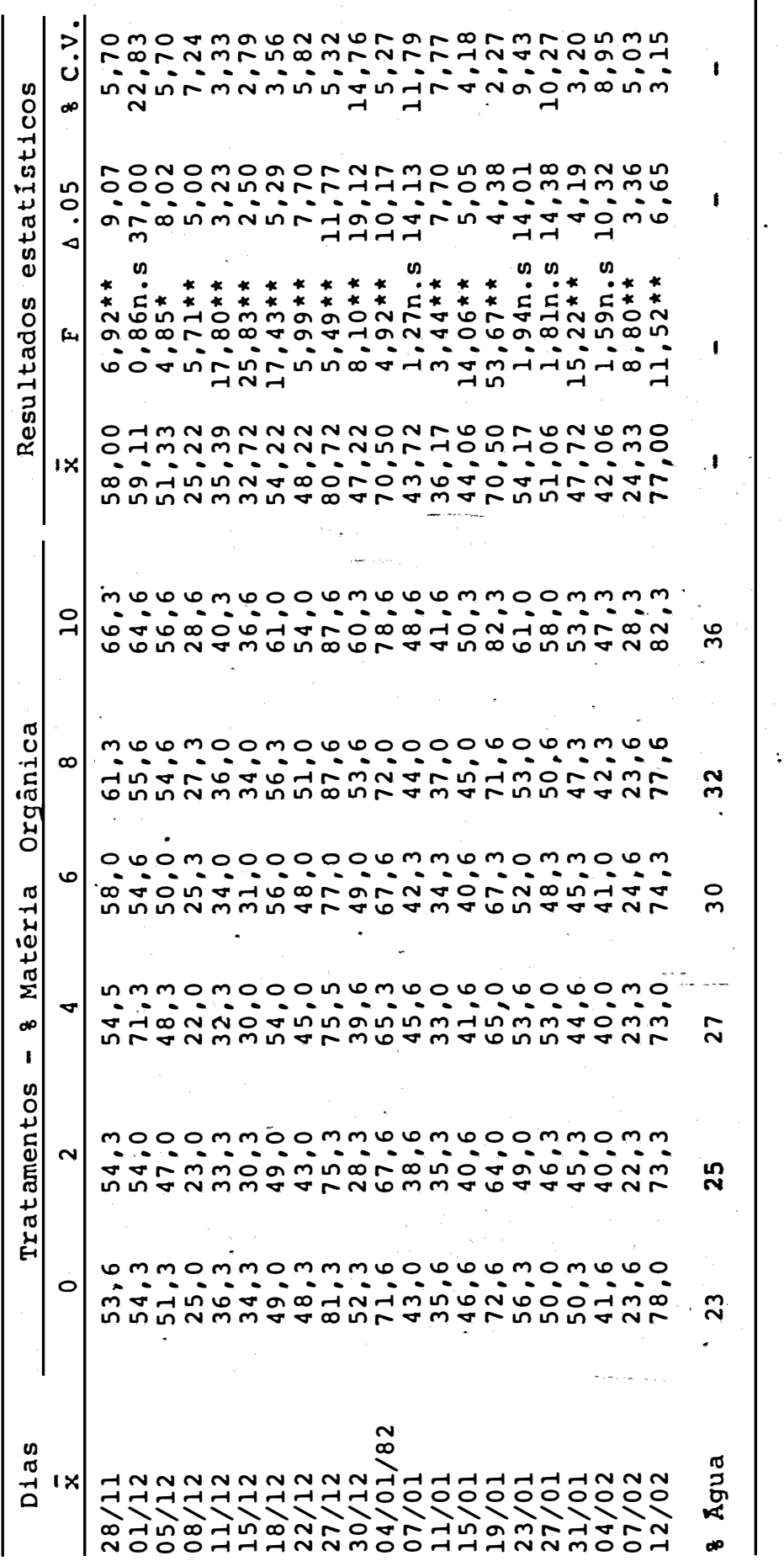


108.
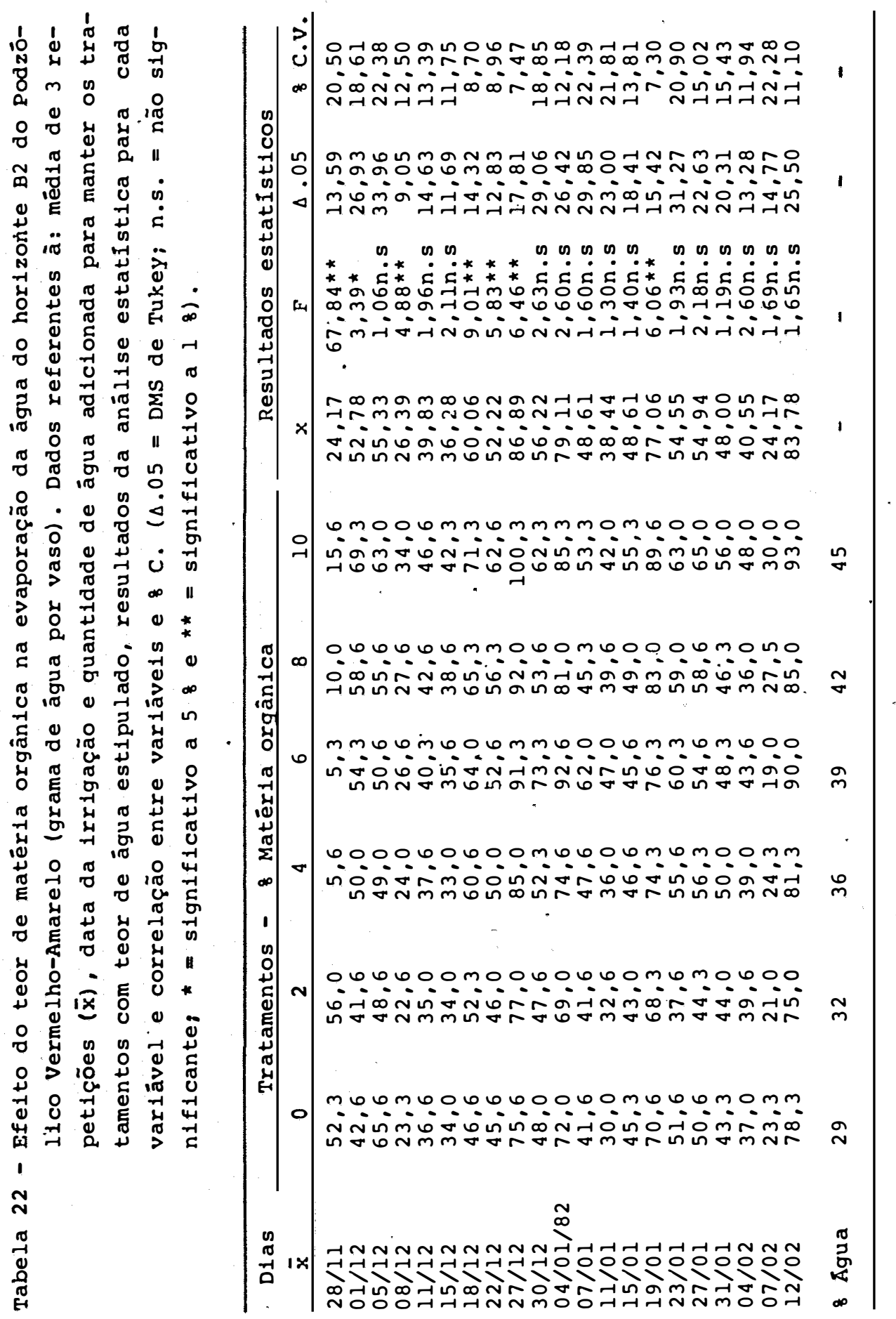
nos tratamentos $10 \& \operatorname{com} 28,48$ e 6 \& de matéria orgânica no Ap e 10 \& com 2 \& e 4 \& de matéria orgânica no B2 do Latossolo Roxo. Verificou-se esses efeitos para o PVA, nos tratamentos $10 \% \operatorname{com} 28,48$ e $6 \%$ no Al; $10 \%$ com 48,68 e 8 \& de matéria orgânica no A2 e $10 \%$ com 0 \& e 2 \& de matéria orgânica no B2.

Dos resultados apresentados é razoável supor que a matéria orgânica apresenta os efeitos direto e indireto na evaporação da água no solo, isto é, pela simples pre sença no solo como tambēm na modificação da estrutura.A ocorrência de um aumento de evaporação com o aumento de matéria orgânica aplicada é indicação desse efeito indireto, pois a presença da matéria orgânica favorece a formação de ligação entre as partículas, o que resulta em um movimento ascendente da água e consequente evaporação. 
5. CONCLUSÕES

A análise e interpretação dos resultados obtidos permitiu tirar-se as seguintes conclusões:

1. Há uma relação linear entre o aumento no: teor de carbono no solo e a quantidade de matéria orgânica aplicada desde que se mantenham as condições para a decomposição microbiana. A liberação de nutrientes reflete a composição do material orgânico utilizado. o teor de carbono tende a diminuir até atingir uma situação de equilíbrio. Há, também, efeitos indiretos da decomposição da maté ria orgânica particularmente no pH da solução do solo.

2. Há um efeito direto da matéria orgânica no teor da fração limo, isto é, pela simples 
presença. Há também, efeito indireto pela agregação de partículas coloidais que passam para a fração limo e de partículas de limo que passam para a fração areia.

3. Há um efeito direto sobre a densidade do solo e da partícula, resultante da simples presença da matéria orgânica. Há,também,um efeito indireto sobre a densidade do solo, - resultante do seu efeito modificador na estrutura do solo.

4. A capacidade de retenção de água no solo aumenta com a adição de teores de matéria orgânica.

5. A evaporação da água no solo durante o perỉodo de incubação da matéria orgânica aumenta com o acréscimo de matéria orgânica. 
6. CONSIDERAÇÕES FINAIS

Os efeitos que a matéria orgânica poderá causar em alguns atributos do solo não estão bem esclarecidos e requerem, ainda, mais informações para que se possa avaliá-los e medi-los quantitativamente. Entretanto, apresenta-se, como conclusão geral mais importante deste trabalho, a afirmação de ợe os efeitos diretos da matéria orgânica no solo devem ser distinguidos de seus efeitos indiretos. Considera-se que esta distinção possibilitará uma melhor compreensão de sua importância. 
7. LITERATURA CITADA

ADAMS, W.A., 1973. The effect of organic matter on the bulk and true densities of some uncultivated podzolic soils. J. Soil Science, 24 (1): 10-17.

ALEXANDER, M., 1967. Mineralization and immobilization of nitrogen. In: ALEXANDER, M., ed. Introduction to soil microbiology. 4 ed. New York, John Wiley, p. 248-271.

ALEXANDROVA, L.N., 1960. On the composition of humus subs tances and the nature of organo-mineral colloids in soil. Vol. II 7th. Int. Congress of Soil Science. Madison Wisconsin USA, p. 74-81. 
ALEXANDROVA, L.N.; O.V. YURLOVA E L.V. LOBITSKAYA, 1964. The distribution and the composition of the humus substances and their organo-mineral derivatives in the granulometric fractions in some types of soil. In: Int. Cong. of Soil Science, Bucharest. Romania, v. 2, p. 109-116.

ALI, M.K. et alii, 1966. Soil moisture tension relationships of some Indian soils. J. Soil Sci., 14: 15-62.

ALLISON, F.E., 1957. Nitrogen and soil fertility. In: ESTEFFERUD, A., ed. Soil; the 1957 Yearbook of agriculture. Washington, D.C., U.S. Governament Printing Office, p. 8593.

ALLISON, F.E., 1973. Soil organic matter and its role in crop production. Amsterdam, Elsevier Scientific, 637 p.

ANDERSON, J.U., 1963. An improved pretreatment for mineralogical analysis of samples containing organic matter. Clays and clay minerals, 10: 380-388.

BAVER, L.D., 1930. The effect of organic matter upon several physical properties of soil. J.Amer. Soc. Agron., $\underline{22}$ : $703-708$. 
BAVER, L.D., 1956. Soil physics. John Wiley \& Sons, Inc. New York, London Sydney, 3a. Ed. 489 p.

BAVER, L.D., 1968. The effect of organic matter on soil structure. In: PROGRESSO EM BIODINAMICA E PRODUTIVIDADE DO SOLO. Anais do II Congresso Latino-Americano de Biologia do Solo, Santa Maria, RS, 553 p.

BAVER, L.D.; S.H. GARDNER e W.R. GARDNER, 1973. Fisi'ca de suelos. México, Union Topográfica Editorial Hispano-Americana, 529 p.

BAVER, L.D. e N.S. HALL, 1937. Colloidal properties of soil organic matter. University of Missouri, 23 p. (Research Bull, 267).

BERKHEISER, V.E., 1981. Comparison of water adsorption by monovalent exchange ion forms of soil humic material and synthetic exchanges. Soil Sci., $131(3):$ 172-177.

BLACK, C.A., 1968. Nitrogen: mineralization and immobilization. In: BLACK, C.A., ed. Soil-plant relationship, 2a. ed. New York. John Wiley, p. 419-452. 
BLAKE, G.R., 1965. Particle density. In: BLAKE, C.A. ed. Methods of soil analysis. A.S.A. Part I p. 371-373 (Agronomy Monograph, 9) .

BOUMA, J. e F.D. HOLE, 1971. Soil structure and hydraulic conductivity of adjacent virgin and cultivated pedons at two sites: a Typic Agrindoll (silt loam) and a Typic Entrochrept (clay). Soil Sci. Soc. Amer. Proc., 35:316-9.

BROERSMA, K. e L.M. LAUKULICH, 1980. "Organic matter dis tribuction with particle-size in surface horizons of some sombric soils in Vancouver Island". Can. J. Soil Sci,,60: 583-586.

BUCKMAN, H.O. e N.C. BRADY, 1967. Natureza e propriedades dos solos. Trad. de A.B. Neiva de Figueiredo Filho. Livraria Freitas Bastos S/A. 5ạ Edição, 647 p.

CATANI, R.A. e A.0. JACINTHO, 1974. Análise química para avaliar a fertilidade do solo. Piracicaba, ESALQ. 54 p. (Bol. Téc. Cient., 37) .

CHEW, W.Y.; C.N. WILLIAMS; K.T. JOSEPH E K. RAMILI, 1976. Studies on the availability to plants of soil nitrogen in Malaysion tropical oligotrophic peat. I - Effect of liming and pH. Trop. Agric., 53: 69-78. 
CLAYTON, J.L. e C.E. JENSEN, 1973. Water retention of granitic soils in the Idaho Batholith. U.S.D.A. Forest Service.

CORNFIELD, A.H., 1952. The mineralization of the nitrogen of soils during incubation: influence of $\mathrm{pH}$, total nitro gen and organic carbon contents. J.Sci. Food Agric. 3: 343-349.

CURTIS, R.O. e E.W. POST, 1964. Estimating bulk density from organic matter content in some vermont forest soils. Soil Sci. Sco. Amer. Proc., 28: 285-6.

DAVIDSON, T., 1975. Soil organic matter fluctuations in some tropical wetland soils in Turrialba, Costa Rica, 25(2): $183-190$.

ESCHNER A.R.: B.O. JONES E R.C. MOYLE, 1957. Properties of 134 soils in six northeastern states. U.S. Forest Serv. Northeast. Forest Expt. Stä., Sat. Paper, 89.

ERNANI, P.R. e C. GIANELLO, 1982. Efeito imediato e residual de materiais orgânicos, adubo mineral e calcário no rendi mento vegetal. Rev. Bras. Ci. Solo, $\underline{6}(2): 119-124$.

E.U.A., 1951. Department of Agriculture. Soil Survey Staff. Soil Survey Manual. Washington, 503 p. (Hand-book no 18). 
EWART, G.Y. e R.P. HUMBERT, 1960. Use of mill waste organic matter in improving hawaiian sugar cane soils. The Hawaiian Planter's record vol. LV (4).

FORSYTHE, W., 1975. Física de suelos; manual de laboratório. San José, Instituto Interamericano de Ciências Agrícolas , 212 p. (Lybros y Materiales Educativos, 25).

FOTH, H.D. e L.M. TURK., 1972. Fundamentals of soil science. 5. ed., New York. John Wiley \& Sons Inc. 454 p.

FREIRE, J.C., 1975. Retenção de umidade em perfil oxissol do município de Lavras, Minas Gerais. Dissertação de Mestrado, Piracicaba, ESALQ, mimeografada, 76 p.

FREIRE, 0., 1967. Agregação de solos, efeito da matéria orgânica, calagem, adubação e vegetação. Tese para obtenção do título de Docente Livre. Departamento de Solos e Geo logia. Piracicaba, ESALQ, 103 p.

GONZALEZ, M.A. e S.A. GAVANDE, 1969. Water retention characteristics of some Costa Rica soils. Turrialba, 19(2): 235245 . 
GREENLAND, D.J., 1965a. Interaction between clays and organic compounds in soils. Part I. Mechanisms of interaction between clays and defined organic compounds. Soils and Fertilizers (5): 415-425.

GREENLAND, D.J., 1965b. Interaction between clays and organic compounds in soils. Part II. Adsorption of soil organic compounds ant its effect on soil properties. Soils and Fertilizers (6): 521-532.

GRISI, B.M., 1978. Método químico de medição da respiração edáfica: alguns aspectos técnicos. Ciência e Cultura, 30: $82-88$.

GROHMANN, F., 1956. Influência da adubação nas características dos agregados do solo da série Chapadão (Latossolo Ro xo). Bragantia, 25: 263-276.

GROHMANN, F. e O.A. CAMARGO, 1973. Influência dos óxidos de ferro livres e da matéria orgânica na adsorção de água pelo solo. Bragantia, $\underline{32}(10): 203-222$.

GROHMANN, F. e H.P. MEDINA, 1962. Características de umidade dos principais solos do Estado de São Paulo. Bragantia, 21. (18) : 285-295. 
GUPTA, U.C. e H.W. REUSZER, 1967. Effect of plant species on the aminoacid content and nitrification of soil organic matter. Soil Sci., 104: 395-400.

HAMBLIN, A.P. e D.B. DAVIES, 1977. Influence of organic matter on the physical properties of some east anglian soils of high silt content. J.Soil Sci., 28(1): 11-22.

HAQUE, I. e D. WALMSLEY, 1972. Incubation studies on mineralization of organic sulphur and organic nitrogen. Plant soil, $37: 256-264$.

HOLLIS, J.M.; R.J.A. JONES E R.C. PALMER, 1977. The effects of organic matter and particle size on the water-retention properties of some soils in the west midlands of England. Geoderma, 17: 225-238.

JEFFREY, D.W., 1970. A note on the use of ignition loss as a means for the approximate estimation of soil bulk density. J. Ecol., 58: 297-9.

JENKINSON, D.S., 1964. Decomposition of labelled plant material in soil. In: Experimental Pedology. Butterworths, London, p. 199-207. 
KIEHL, E.J., 1979. Manual de Edafologia. Relações Solo-Planta. Ed. Agronômica Ceres, 263 p.

KIEHL, E.J.; T. KINJO e Z.Z. MARCOS, 1972. Caracterização e interpretação das propriedades do solo. 2a ed. Piracicaba, ESALQ. Depto de Solos e Geologia, 119 p. (mimeografado).

KIRKHAM, D. e W.V. BARTHOLOMEU, 1954. Equations following nutrient transformation in soil, utilizing tracer data. Soil Sci.Soc. Amer. Proc., 18: 33-34.

KLUTE, A. e W.C. JACOB, 1949. Physical properties of "Sassafras silt loam as affected by long-time organic matter additions. Proc. Soil Sci. Sóc. Amer., 14: 24-8.

LATHWELL, D.J. e D.R. BOULDIN, 1981. Soil organic matter and soil nitrogen behaviour in cropped soils. Trop. Agric. 58 $(4): 341-349$.

LAVKULICH, L.M. e J.H. WIENS, 1970. Comparison of organic matter destruction by hydrogen peroxide and sodium hypochlorite and its effects on selected mineral constituents. Soil Sci. Soc. Amer. Proc. ( 34$)$ : 755-758. 
LAWS, W.D. e D.D. EVANS, 1949. The effects of long-time cultivation on some physical and chemical properties of two Rendzina soils. Proc. Soil Sci. Soc. Amer., 14: 15-19.

MACLEAN, A.H. e T.V. YAGER, 1972. Available water capacities of Zambian soils in relation to pressure plate measurements and particle size analysis. Soil Sci., 113(1): 23-29.

MCKEAGUE, J.A., 1971. Organic matter in particle-size and specific gravity pactions of some Ah horizons, Can J. Soil. Sci., 5l: 499-505.

MILL, J.A., 1967. A system of logic. London, Longmans, Green \& Co. tdt. 622 p.

MOLDENHAUER, W.C.; W.H. WISCHMEIER e D.T. PARKER, 1967. The influence of crop management on runoff, erosion, and soil properties of a Marshall silty clay loam. Proc. Soil Sci. Soc. Amer., 21: 541-6.

MOZART, M.F., 1980. O ponto de inflexão da curva característica de umidade como estimativa da capacidade de campo. Dissertação de Mestrado. Piracicaba. ESALQ. 55 p (mimeo grafada). 
ODELL, R.T.; T.H. THORNBURN e L.J. MC KENSIE, 1960. Relationships of Atterberg limits to some other properties of Illinois soils. Proc. Soil Sci. Soc. Amer. . 24: 297-300.

OVCHINNIKOVA, M.F.; G.V. EREMINA e D.S. ORLOV, 1978. Humus group composition characteristics and seasonal dynamics of certain properties in Virgin and cultivated Soddy-Podzolic Soils. Pochvovedenie, 33(3): 38-46.

PAGE, J.B. e C.J. WILLARD, 1946. Cropping systems and soil properties. Proc. Soil Sci. Soc. Amer., 11: 81-8.

PAIVA NETO, J.E., 1942. A"fração argila" dos solos do Estado de São Paụlo e seu estudo roentgenográfico. Bragantia, 2 $355-432$.

PALLETTO, E.A., 1978. Estudo sobre dispersão de amostras de terra. Dissertação de Mestrado. ESALQ. 68 p. (mimeografado).

PAUL, E.A. e J.A. VAN VEEN, 1978. The use of tracers to determine the dynamic nature of organic matter. In: Int. Congr. Soil Sci., 11, Edmonton, 1978. Trans. Edmonton, International Society of Soil Science, $\underline{3}$ : 61-102. 
PETERSEN, G.W.; R.L. CUNNINGHAM e R.P, MATELSKI, 1968a. Moisture characteristics of Pennsylvania soils: I. Moisture retention as related to texture. Soil Sci. Soc. Amer. Proc., $\underline{32}(2): 271-275$.

PETERSEN, G.W.; R.L. CUNNINGHAM e R.P. MATELSKI, 1968b. MOisture characteristics of Pennsylvania soils: II. Soil factors affecting moisture retention within a textural classsilt loam. Soil Sci. Soc. Amer. Proc., 32(6): 866-870.

POTTKER, D. e M.J. TEDESCO, 1979. Efeito do tipo e tempo ! de incubação sobre a mineralização da matéria orgânica e nitrogênio total em solos do Rio Grande do Sul. Rev. Bras.Ciência' do Solo, $3=20-24$.

RANZANI, G.; O. FREIRE: e T. KINJO, 1966. Carta de solos do Municipio de Piracicaba. Piracicaba, ESALQ, 85 p.

REEV, M.J.; P.D. SMITH e A.J. THOMASSON, 1973. The effect of density on water retention properties of field soils. J. Soil Sci., 24(3): 355-367.

RICHARDS, L.A. e M. FIREMAN, 1943. Pressure-plate apparatus for measuring sorption and transmisson by soils. Soil Sci., 56: $395-404$. 
RUSSELL, J.S., 1964. Mathematical expression of seasonal changes in soil organic matter. Nature, 204: 161-162.

SAINI, G.R., 1966. Organic matter as a measure of bulk density of soil. Nature, London, 210: 1295-6.

SALTER, P.J.; G.R. BERRY e J.B. WILLIAMS, 1967. The effect of farmyard manure on matric suctions prevailing in a sandy loam soil. J. Soil Sci., 18(2): 318-328.

SALTER, P.J. e J.B. WILLIAMS, 1963. The effect of farmyard manure on the moisture characteristic of a sandy loam soil. J. Soil Sci., 14(1): 73 .

SALTER, P.J. e J.B. WILLIAMS, 1965. The influence of texture on the moisture characteristics of soils. II. Available water capacity and moisture release characteristics. J. of Soil Sci., 16 12$): 310-317$.

SALTER, P.J.e J.B. WILLIAMS, 1967. The influence of textur re on the moisture characteristics of soils. IV. A method of estimating the available-water capacities of profiles in the field. J. Soil Sci., 18(1): 174-181. 
SAMPAIO, E.V.S.B. e I.H. SALCEDO, 1982. Decomposição de palha de milho marcada e incorporação do ${ }^{14} \mathrm{C}$ à biomassa microbiana de um Latossolo Vermelho-Amarelo. R. bras. Ci.So10, 6: $29-32$.

SANCHES, P.A., 1976. Properties and management of soils in the tropics. New York, John Wiley \& Sons, Inc.

SANTOS, 0.M., 1979. Atividade microbiana em solos de cacaual sob influência do sombreamento e adubação. R. Theobroma, 9: $13-23$.

SHETRON, S.G., 1974. Distribution of free iron and organic carbon as related to available water in some forested sandy soils. Soil Sci. Soc. Amer. Proc., 38(2): 359-362.

STEWART, V.I.; W.A. ADAMS e H.H. ABDULLA, 1970. Quantitative pedological studies on soils derived from Silurian mudstones. II. The relationship between stone content and apparent density of the fine earth. J. Soil Sci., 21: 248-55.

STURGIS, M.B., 1957. Managing soils for rice. In: STEFFERUD, A., ed. Soil; the 1957 Yearbook of Agriculture.Washington, D.C., U.S. Government Printing Office, pp. 658-662. 
VAN RAIJ, B., 1969. A capacidade de troca de cátions das frações orgânicas e mineral em solos. Bragantia, 28: 85112.

VERDADE, F.C., 1954. Ação da āgua oxigenada sobre a maté ria orgânica do solo. Bragantia, 13(24): 287-295.

VERDADE, F.C., 1956. Influência da matéria orgânica na capacidade de troca de cátions do solo. Bragantia, 15: 3542.

WAKSMAN, S.A., 1938. Humus origen, chemical composition, and importance in nature. 2? ed., Baltimore. The Wil liams \& Wilkins Company, $584 \mathrm{p}$.

WILLIAMS, R.J., 1970. Relationships between the composition of soils and physical measurements made on them. Rep. Rothamsted Exp. Stn. 2,5-35, pt. 2, 5-35.

WINKLE, E.I.G. e S.J. GOEDERT, 1972. Características hïdricas dos solos de Pelotas, RS. Pesq. Agropec. Bras., Série Agron., $7: 1-4$ 
128.

APENDICE 
8. PREPARO DOS TRATAMENTOS PARA A INSTALAÇÃo DE UMA CULTURA DE PAINÇO (Setalia italica, Beauv).

Como é sabido, a mineralização da matéria orgânica, libera, no solo, fósforo e outros elementos. Com o propósito de verificar essa liberação, resolveu-se instalar, nos mesmos vasos, contendo os tratamentos em estudo, uma lcultura de painço (Setalia italica, Beauv), que é uma planta indicadora de fósforo. Para tanto procedeu-se da seguinte maneira:

a. Terminado o período de incubação aeróbica, o restante da amostra foi retirada de cada vaso e colocada em bandeja de alumínio, deixada secar à sombra, destorroada e passada em peneira de $2 \mathrm{~mm}$ de malha e recolocada nos seus respectivos vasos.

b. Determinou-se o peso da terra nos vasos e utilizando novamente os dados da Tabela 4 estabeleceu-se a 
quantidade de água a ser adicionada a cada vaso para manter o mesmo teor adotado na incubação. A irrigação foi feita de 2 em 2 dias, e controlada por pesagem do vaso para se obter 0 peso da água evaporada.

c. Foram plantadas em cada vaso 40 sementes com poder de germinação de 80 \%. Foi feito um desbaste quatro dias após o plantio, deixando apenas 10 plantas por vaso.

d. Os vasos foram dispostos sobre uma mesa,dentro do laboratório de Física do Solo da ESALQ. Sobre os vasos, a $90 \mathrm{~cm}$ de altura, instalou-se um conjunto de luz para simular a iluminação solar. A temperatura do ar, nesse ambiente artificial, variou diariamente entre um máximo de $42^{\circ} \mathrm{C}$ e um mínimo de $26^{\circ} \mathrm{C}$. A umidade relativa do ar, no ambiente do laboratório, variou entre $67 \&$ e $50 \%$ durante a duração do experimento (de 24 de junho a 22 de julho de 1982).

e. Após 30 dias, a parte aérea da planta foi coletada, pesada e, em seguida, levada à estufa com temperatura controlada $\left(50-60^{\circ} \mathrm{C}\right)$ até peso constante, obtendo-se assim o peso da matéria seca. 
131.
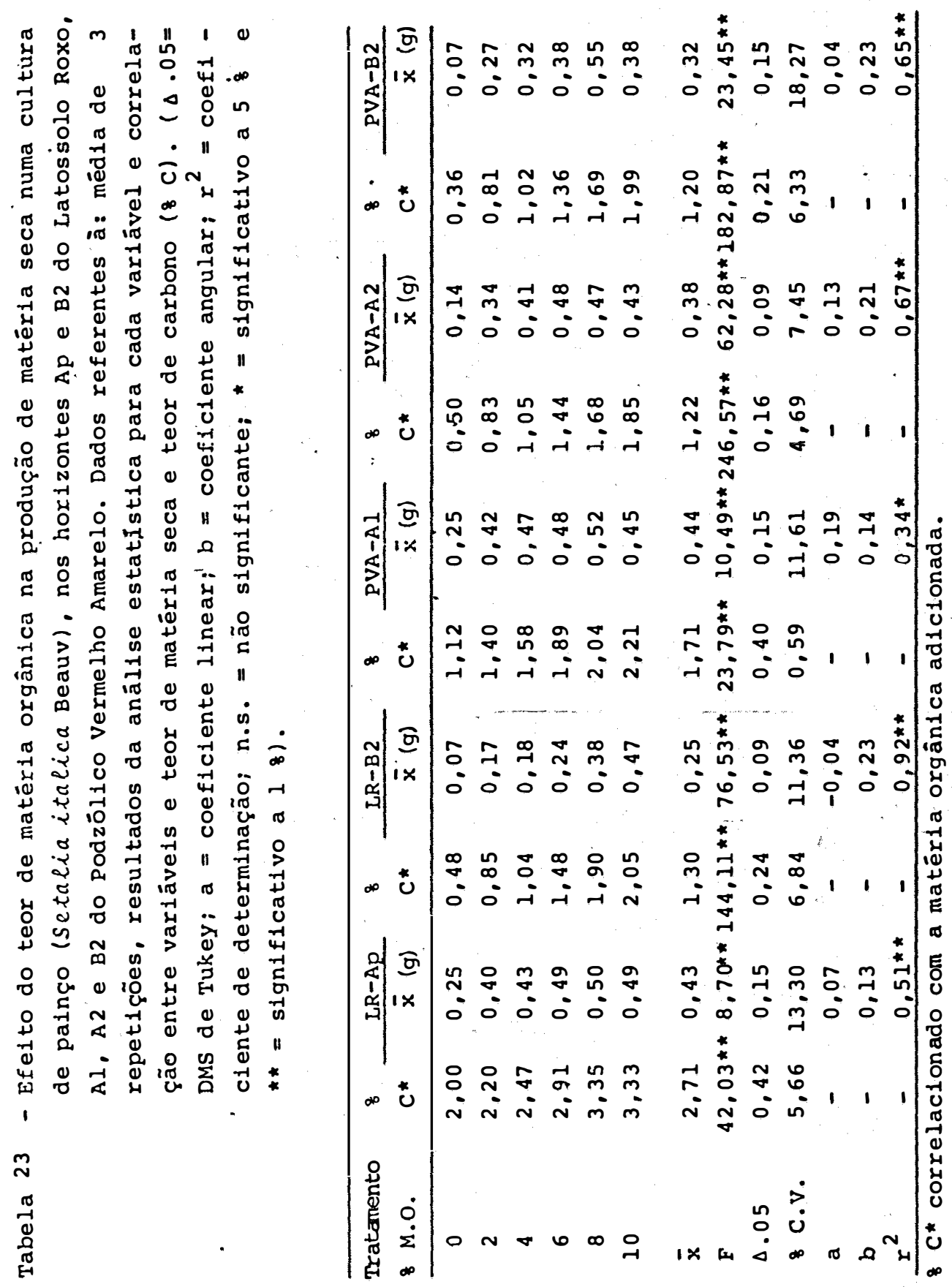

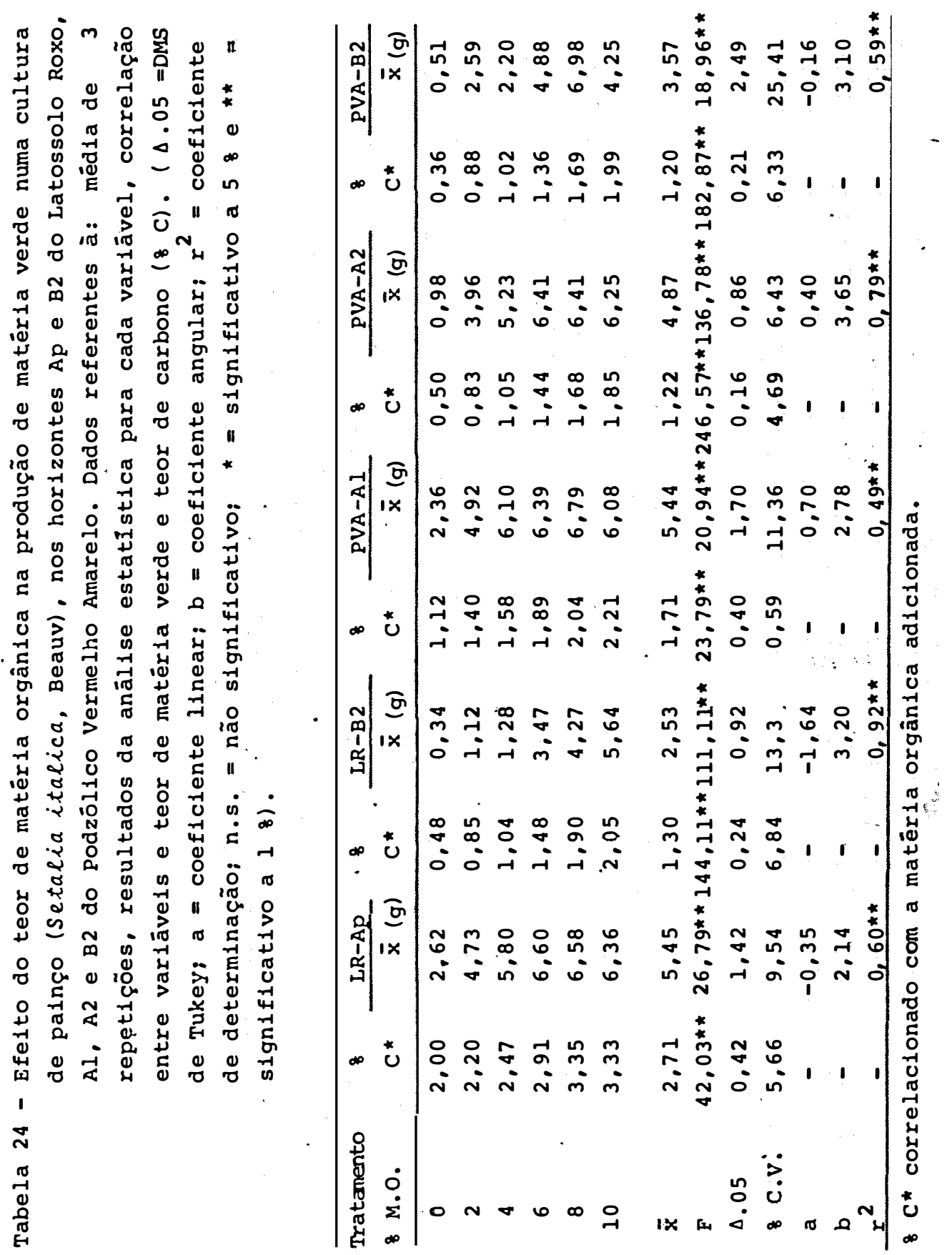


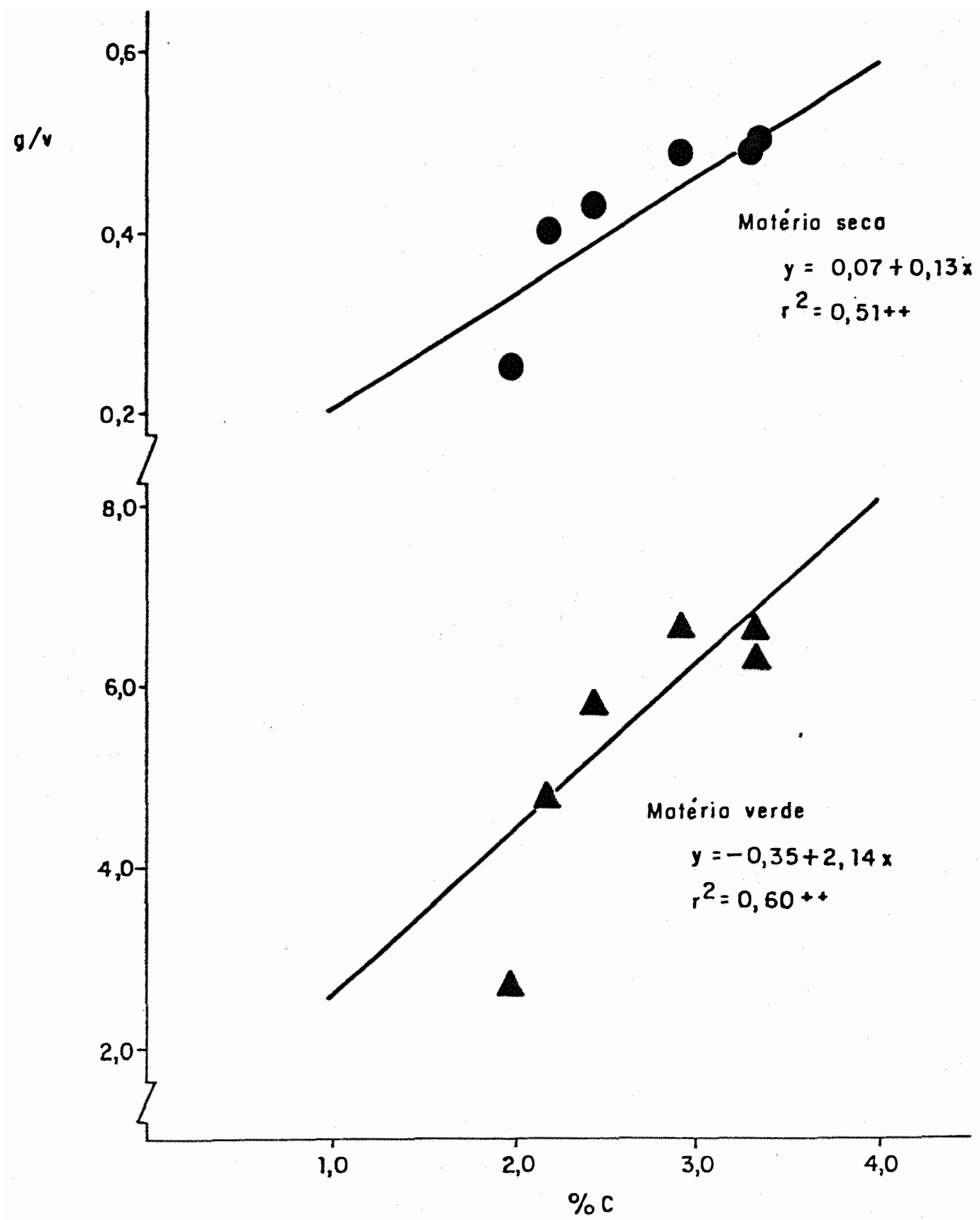

Figura 22 - Gramas de matéria verde (m.v) e gramas de matēria seca (m.s) em 10 plantas por vaso, em relação ao \& C, após o período de incubação da matéria orgânica adicionada ao horizonte Ap do Latossolo Roxo. 


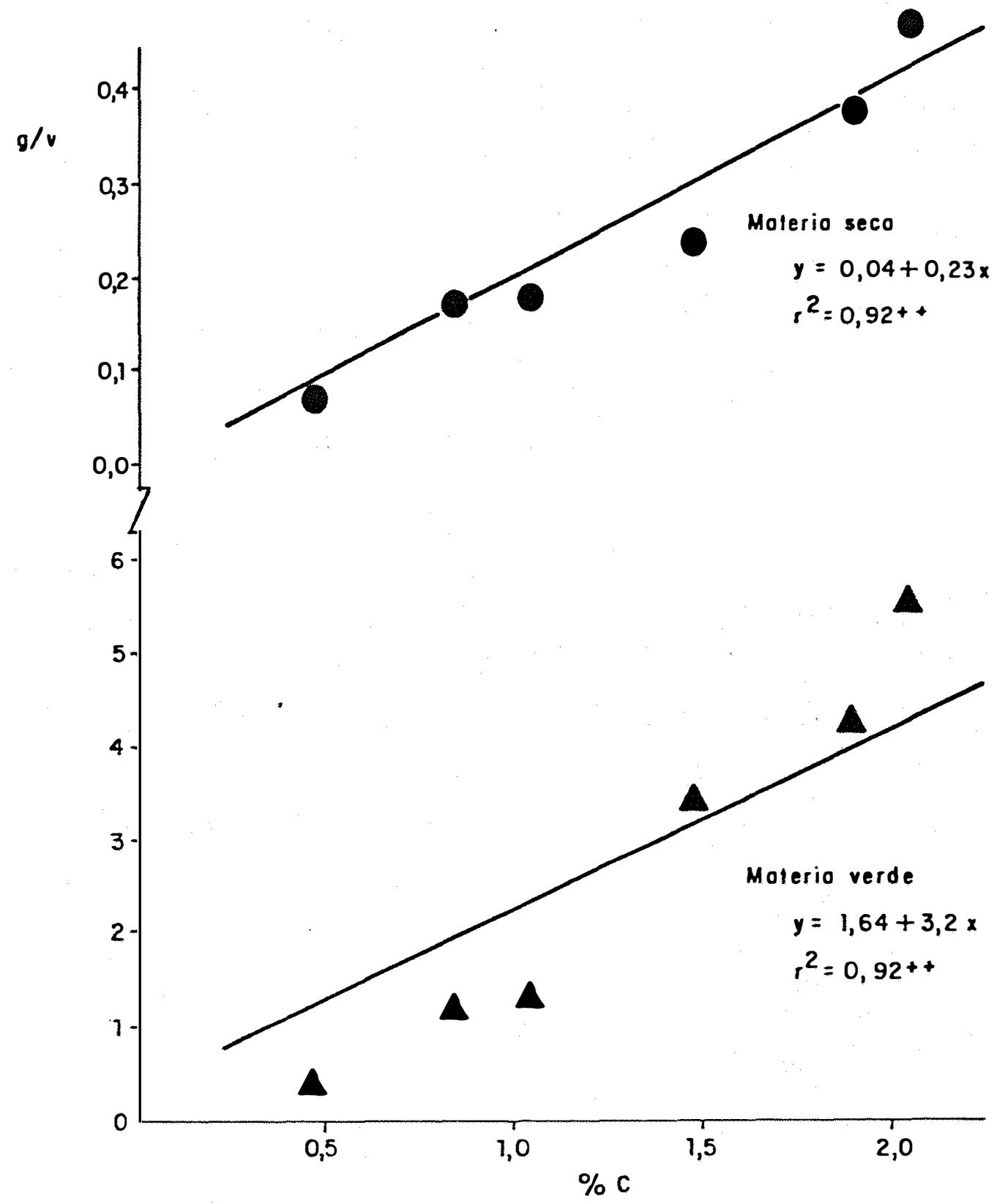

Figura 23 - Gramas de matéria verde (m.v) e gramas de matéria seca (m.s) em 10 plantas por vaso, em relação ao \& C, após o período de incubação da matēria orgânica adicionada ao horizonte B2 do Latossolo Roxo. 


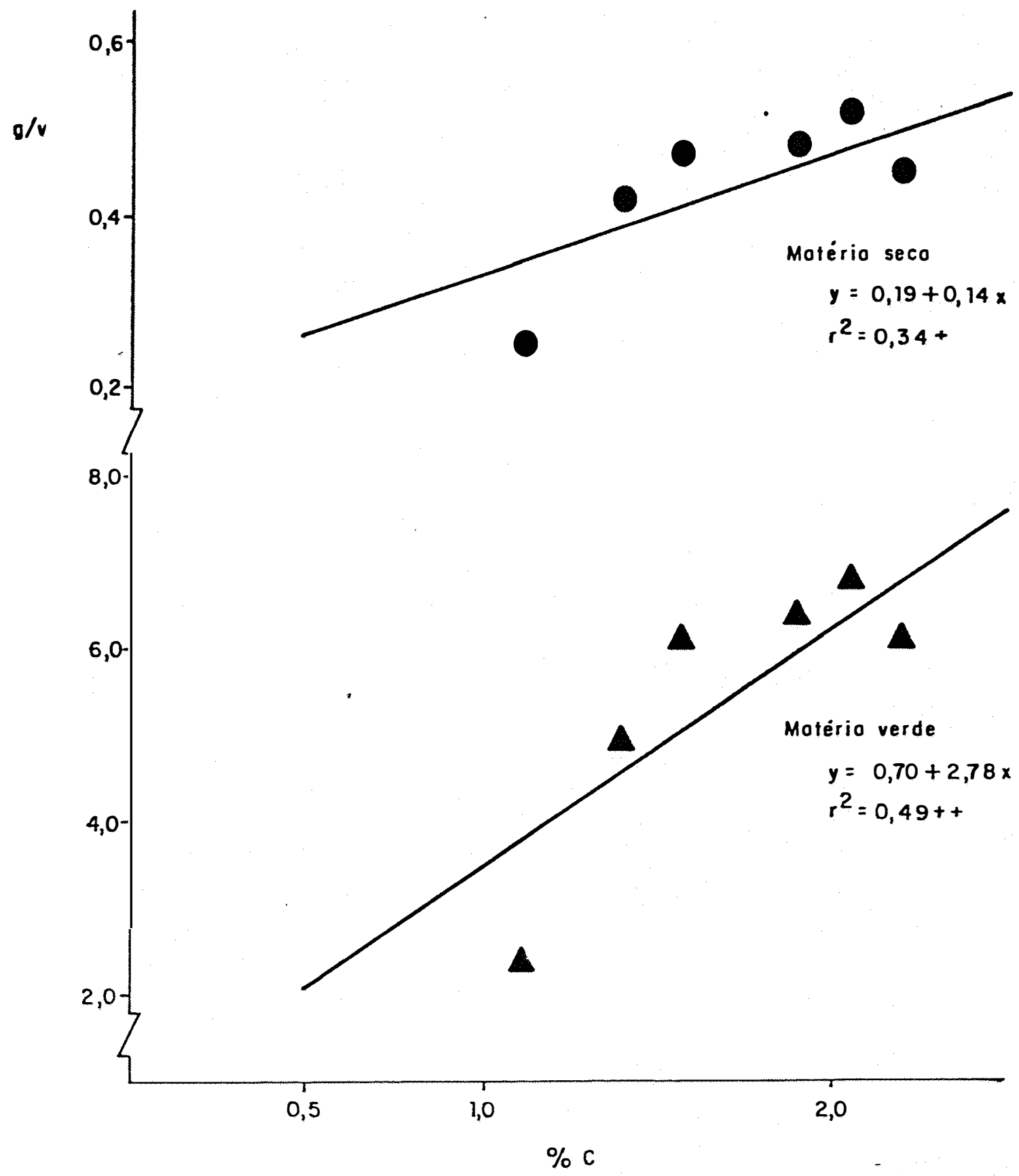

Figura 24 - Gramas de matéria verde (m.v) e gramas de matéria seca (m.s) em 10 plantas por vaso, em relação ao \& $C$, após o período de incubação da matéria orgânica adicionada ao horizonte Al do Podzólico Vermelho-Amarelo. 


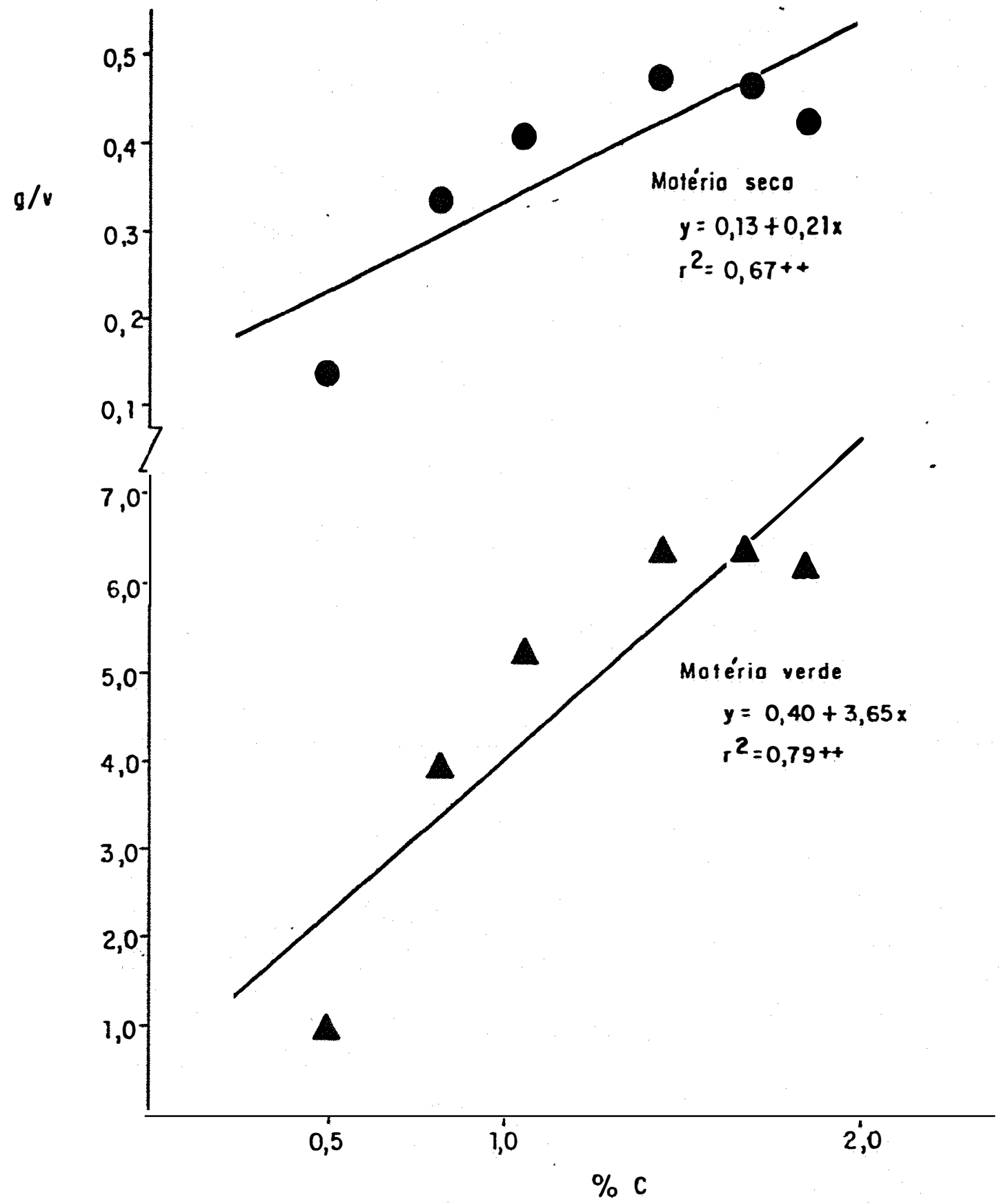

Figura 25 - Gramas de matéria verde (m.v) e gramas de matéria seca (m.s) em 10 plantas por vaso, em relação ao \& $C$, após o período de incubação da matéria orgânica adicionada ao horizonte A2 do Podzólico Vermelho-Amarelo. 


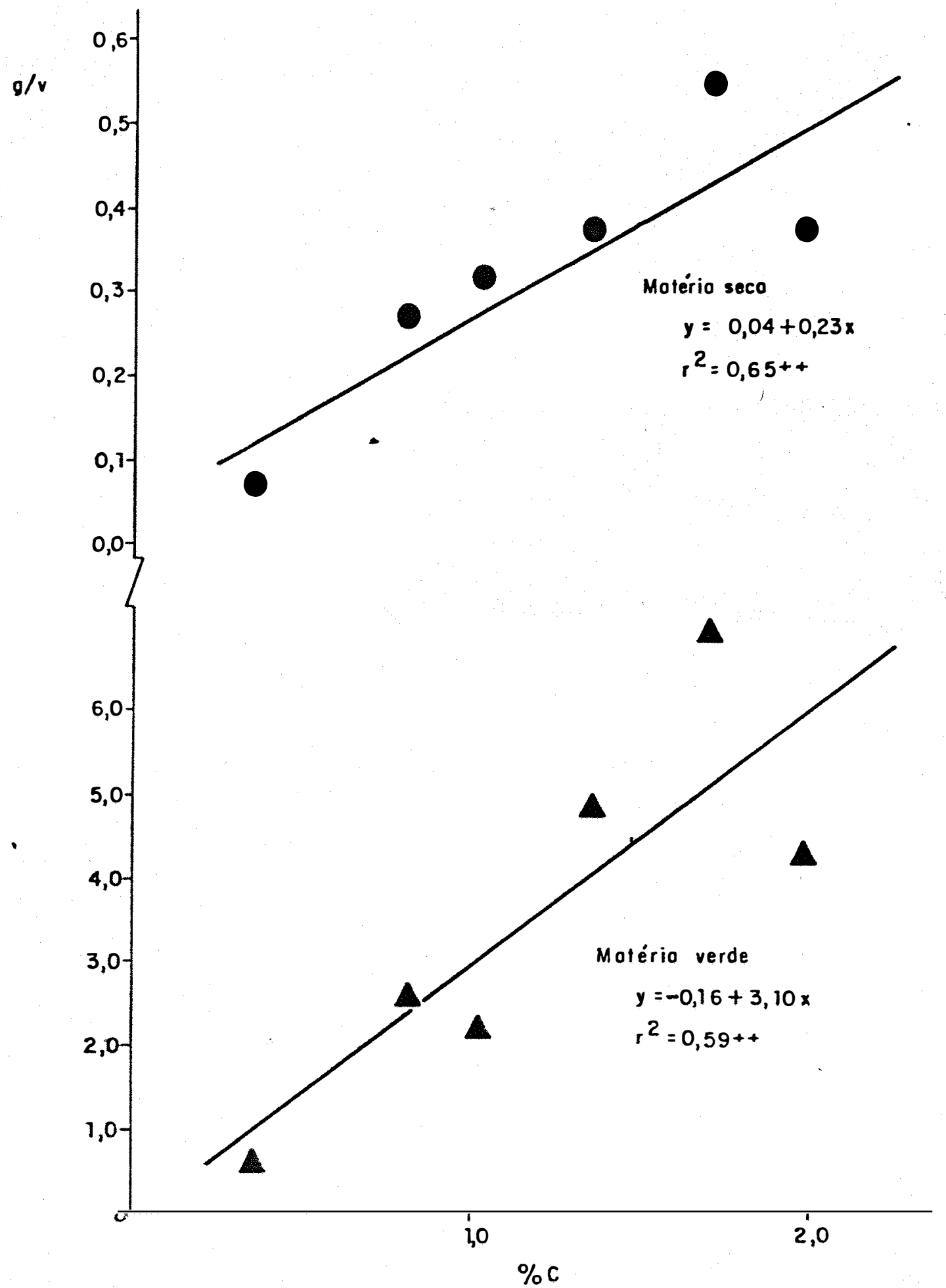

Figura 26 - Gramas de matēria verde (m.v) e gramas de matéria seca (m.s) em 10 plantas por vaso, em relação ao \& C, após o período de incubação da matēria orgânica adicionada ao horizonte B2 do Podzólico Vermelho-Amarelo. 